\title{
МАТЕРІАЛИ КОНГРЕСУ АНЕСТЕЗІОЛОГІВ УКРАЇНИ
}

\author{
13-15 вересня 2018 року
}

\section{Андрущак А.В., Коновчук В.М., Кушнір С.В. \\ ОСОБЛИВОСТІ ВОЛЮМО- ТА ОСМОРЕГУЛЯТОРНОЇ ФУНКЦІЇ НИРОК У ПАЦІЄНТІВ ІЗ КОМПЕНСОВАНОЮ СЕПСИС-ІНДУКОВАНОЮ ГІПОТЕНЗІЕЮ}

УДК 616.61-002;616-085+616.12-008

\author{
Кафедра анестезіології та реаніматології ВДНЗ \\ Буковинський державний медичний університет
}

\begin{abstract}
АКТУАЛЬНІСТЬ
Сучасні погляди на інтенсивну інфузійну терапію перебігу сепсису зосереджені на рекомендаціях щодо надання пріоритетів застосуванню препаратів кристалоїдного ряду [1]. Враховуючи поліморфізм патогенезу сепсису, поліорганність та взаємообтяжливість слід рахувати, що такий арсенал засобів інтенсивної терапії не завжди задовольняє патогенетичне обгрунтування базової складової програми інтенсивної терапії сепсису $[2,3]$. У звјязку з цим звернули увагу на властивості та спектр дії похідних багатоатомних спиртів, а саме сорбітолу, на волюмо- та осморегуляторну функції нирок у пацієнтів 3 сепсис-індукованою гіпотензією.
\end{abstract}

\section{META РОБОТИ}

Дослідити реакцію волюмо- та осморегуляторної функції нирок на дію реосорбілакту при дофамін-залежній компенсації сепсис-індукованої гіпотензії.

\section{МАТЕРІАЛ ТА МЕТОДИ}

Критерії включення - пацієнти з гнійно-септичними ускладненнями 3 дофамін-залежною компенсацією (5-10 мкг/кг'хв) та належною інфузійною терапією за стартовими показниками: САТ > 70 мм.рт.ст., АТс > $>95$ мм.рт.ст., ЦВТ > 4 мм.рт.ст., діурезу > 30мл/год. Контрольні дослідження - пацієнти з синдромом системної запальної відповіді (ССЗВ), котрі відповідали класифікатору MKX-10: SIRS, ICD-10: R-65.2. Пацієнти були розподілені на 4 групи: I гр. та II гр. - контрольні дослідження (СС3B, n=25); III гр. та IV гр. - сепсисіндукована гіпотензія $(\mathrm{n}=28)$. Пацієнти II гр. та IV гр. додатково отримували інфузійне навантаження реосорбілактом в кількості 7-8 мл/кг зі швидкістю 18-20 мл/хв.

\section{РЕЗУЛЬТАТИ}

Результати досліджень впливу реосорбілакту на волюмота осморегуляторну функції нирок у хворих 3 сепсисіндукованою гіпотензією характеризуються активацією діурезу (на $224 \pm 58,9 \% ; \Delta, \mathrm{P}<0,05$ ), збільшенням кліренсу натрію (на $317 \pm 52,5 \% ; \Delta, \mathrm{p}<0,05$ ) та кліренсу осмотично активних речовин (на $240 \pm 68,6 \% \Delta, \mathrm{p}<0,05)$. При цьому швидкість клубочкової фільтрації зросла на $54 \pm 11,7 \%$ $(\Delta, \mathrm{p}<0,05)$. В основі активуючої дії реосорбілакту знаходяться процеси, що пригнічують реабсорбовану фракцію натрію на $1,58 \pm 0,29 \%(\Delta, \mathrm{p}<0,05)$ та реабсорбовану фракцію осмотично активних речовин на $4,2 \pm 1,40 \%$ $(\Delta, \mathrm{p}<0,05)$.

\section{ВИСНОВКИ}

В раніше отриманих даних зареєстровано, що при дофамін-залежній компенсації сепсис-індукованої гіпотензії спостерігається за кліренсовими характеристиками депресія волюмо- та осморегуляторної функції нирок. Інфузійне навантаження реосорбілактом хворим 3 компенсованою сепсис-індукованою гіпотензією сприяє забезпеченню відновлення компенсаторних об ємзалежних реакцій, волюмо- та осморегуляторної функції нирок.

\section{СПИСОК ЛІТЕРАТУРИ} . Сорокина Е.Ю., Дубров С.А. (2016) Новый шаг в диагностике $u$ ANAESTHESIA \& INTENSIVE CARE, $4,8-15$.

2. Hoste, E., Maitland, K., Brudney, C., Mehta, R., Vincent, J., Yates, D., Kellum, J., Mythen, M and Shaw, A. (2014). Four phases of intravenous fluid therapy: a conceptual model. British Journal of Anaesthesia, $113(5)$, pp.740-747.

3. Avni, T., Lador, A., Lev, S., Leibovici, L., Paul, M. and Grossman, A.(2015).Vasopressors for the Treatment of Septic Shock: Systematic Review and Meta-Analysis. Plos One, 10(8), p.e0129305

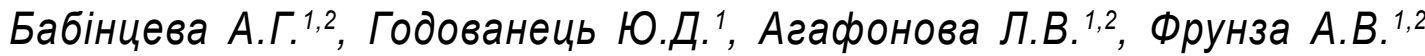 ГОСТРЕ ПОШКОДЖЕННЯ НИРОК У НОВОНАРОДЖЕНИХ ДІТЕЙ: ОСНОВНІ ПРИНЦИПИ ПРОФІЛАКТИКИ ТА ІНТЕНСИВНОЇ ТЕРАПІЇ В РАННЬОМУ НЕОНАТАЛЬНОМУ ПЕРІОДІ}

${ }^{1}$ Вищий державний навчальний заклад України “Буковинський державний медичний університет», кафредра педіатрії, неонатології та перинатальної медицини, м.Чернівці, Україна

2 Міська комунальна медична установа «Клінічний пологовий будинок №2», відділення інтенсивної терапії новонароджених, м.Чернівці, Україна

\section{АКТУАЛЬНІСТЬ}

У сучасній науковій літературі значна увага приділяється питанням лікування гострого пошкодження нирок (ГПН) у новонароджених дітей, метою якого $е$ підтримка гомеостазу до повного відновлення ниркових функцій [1]. Але на сьогодні відсутні уніфіковані міжнародні та національні стандарти профілактики та лікування ниркових пошкоджень у новонароджених дітей 3 тяжкою перинатальною патологією.

\footnotetext{
О Андрущак А.В., Коновчук В.М., Кушнір С.В. , 2018

- Бабінцева А.Г., Годованецьь Ю.Д., Агафонова Л.В., Фрунза А.В., 2018
} 
MATERIALS OF THE CONGRESS OF ANAESTHESIOLOGISTS OF UKRAINE September 13-15, 2018

\section{META}

Удосконалити алгоритм попередження та лікування ГПН у новонароджених дітей 3 тяжкою перинатальною патологією та оцінити його ефективність.

\section{МАТЕРІАЛИ ТА МЕТОДИ}

Проведено комплексне клініко-параклінічне обстеження 100 доношених новонароджених дітей 3 перинатальною патологією тяжкого ступеня, 3 яких 60 дітям було призначено удосконалений терапевтичний комплекс (основна група), 40 дітей отримували загальноприйняту терапію (група порівняння).

Комплекс терапевтичних заходів у відділенні інтенсивної терапії новонароджених (BITH) передбачав забезпечення фізіологічних умов зовнішнього середовища 3 усуненням дії подразнюючих чинників; ефективного немедикаментозного та медикаментозного знеболення; залучення матерів/батьків у нагляді та виходжуванні дітей максимально раннього початку ентерального вигодовування грудним молоком; ефективної дихальной підтримки; адекватного волемічного статусу; підтримки енергетичних та пластичних потреб організму; адекватної перфузії шляхом корекції артеріальної гіпотензії; емпіричної антибіотикотерапії (за показами); менеджмент пре- та ренального типу ГПН.

Новонародженим основної групи, поряд із традиційними заходами стабілізації гомеостазу, було призначено засіб групи метилксантинів, діючою речовиною якого $\epsilon$ теофілін, для попереджання аденозин-індуковано ренальної вазоконстрикції [2] та препарат комплексно антигіпоксичної й антиоксидантної дії, до складу якого входять янтарна кислота, нікотинамід, рибоксин, рибофлавін [3].

\section{РЕЗУЛЬТАТИ}

Застосування удосконаленого комплексу лікування, порівняно з традиційною терапією, надало змогу суттєво покращити якість функціонування сечовидільної системи при тяжких формах перинатальної патології, зокрема
PAIN ANAESTIHESSIA \& INTENSIVE CARE WR 2018

зменшити частоту випадків формування ГПН $(18,3 \%$ проти $37,5 \%, \mathrm{p}<0,05)$. При лікуванні новонароджених відмічалося зростання погодинного діурезу, зменшення рівня креатиніну у сироватці крові, збільшення швидкості клубочкової фільтрації, покращення основних допплерометричних показників ренального кровоплину та стабілізація балансу маси тіла. Стимуляція антиоксидантного ефекту захисту організму підтверджувалося суттєвим зменшенням рівня малонового альдегіду в еритроцитах та окисної модифікації білків у плазмі крові, збільшенням активності глюкозо-6-фосфатдегідрогенази в еритроцитах, глутатіонредуктази та глутатіон-Sтрансферази у плазмі крові. Призначення удосконаленого комплексу лікувально-профілактичних заходів у пацієнтів ВІTН надало змогу значно збільшити частоту переводу дітей у відділення неонатального догляду, зменшити частоту транспортування хворих дітей у відділення інтенсивної терапії педіатричних закладів, зменшити загальне фармакологічне навантаження на організм дітей, а також зменшити ліжко-дні у ВITH, тривалість проведення штучної вентиляції легенів та використання препаратів інотропної підтримки, сечогінних препаратів.

\section{ЗАКЛЮЧЕННЯ}

Результати проведеного дослідження засвідчили доцільність використання удосконаленого комплексу лікування для профілактики та лікування ГПН у новонароджених дітей в ранньому неонатальному періоді.

\section{СПИСОК ЛІТЕРАТУРИ}

1. Pandey V. Non-dialytic management of acute kidney injury in newborns V. Pandey, D. Kumar, P. Vijayaraghavan // J. Renal. Inj. Prev. 2017; 6(1): 1-11. DOI: 10.15171\%2Fjrip.2017.01.

2. Sathe K.P. Review article: role of methylxanthines in preventing acute renal failure in hypoxic newborns / K.P. Sathe, A. Kulkarni // Apollo Medicine [Internet]. 2015; 12(1) :234-38. DOI:10.1016/ j.apme.2015.02.009.

3. Скоромеи А.П. Повыщение эффективности терапии новорожденных доношенных детей с тяжелой асфиксией в родах А.П. Скоромеи, Л.М. Щугарева, С.В. Шумилина и др. // Журнал неврологи и психиатрии им. С.С.Корсакова. 2016; 4(2): 83-88.

Бєлих О.B.

\title{
ВИВЧЕННЯ ПРОБЛЕМИ ЗАСТОСУВАННЯ РЕГІОНАРНИХ МЕТОДІВ АНЕСТЕЗІЇ ПРИ ЛАПАРОСКОПІЧНИХ ОПЕРАЦІЯХ В ОСІБ ПОХИЛОГО ВІКУ
}

\author{
Харківська медична академя післядипломної освіти
}

\section{АКТУАЛЬНІСТЬ ПРОБЛЕМИ}

Останнім часом увагу науковців привертають методи проведення анестезії при лапароскопічних операціях в абдомінальній хірургії, зокрема в осіб похилого віку, які внаслідок наявності супутніх захворювань є групою підвищеного ризику. Тому удосконалення методів анестезіологічного забезпечення наразі є актуальною проблемою

\section{META РОБОТИ}

Провести порівняльний аналіз ефективності та безпечності регіонарних методів знеболення при лапароскопічних втручаннях в осіб похилого віку.

\section{МАТЕРІАЛИ ТА МЕТОДИ}

Публікації періодичних видань та наукометричних баз за останні 5 років.

\section{РЕЗУЛЬТАТИ}

Епідуральна анестезія при лапароскопічній холецистектомії нерідко застосовується у літніх пацієнтів через певні переваги та невелику кількість ускладнень [3].

Найпоширенішим регіонарним методом при лапароскопії $\epsilon$ спінальна анестезія, перевагами якого $є$ рівномірне глибоке розслаблення м'язів, ясна свідомість, спонтанне дихання, менша частота післяопераційних нудоти та блювання. Недоліками методу є: необхідність більш високого сенсорного блоку, дискомфорт у ділянці плеча внаслідок подразнення діафрагмального нерва, порушення функції зовнішнього дихання через пневмоперитонеум [2].

Селективні варіанти спінальної анестезії дозволяють блокувати зону операції за допомогою введення невеликих доз місцевих анестетиків, що сприяє зменшенню гемодинамічних порушень [4]. Продовжена спінальна анестезія створює можливість зменшення частоти гіпотонії, брадикардії та зниження потреби у вазопресорах [5].

Комбінована спінально-епідуральна анестезія, проти ізольованої епідуральної, забезпечує швидкий початок анестезії, а на відміну від спінальної - необхідність у меншій кількості інтратекальних доз місцевих анестетиків [6].

Порівняльне дослідження застосування комбінованої загальної внутрішньовенної анестезії, комбінованої інгаляційної анестезії із севофлураном та комбінованої спінальної анестезії із бупівакаїном при лапароскопічній холецистектомії показало переваги останнього [1]. 


\section{ВИСНОВОК}

Пошук ефективних і безпечних методів знеболення триває, про що свідчить аналіз наукової літератури. Показано переваги використання регіонарних методів анестезії при лапароскопічній холецистектомії. Попри безпечність методу, значним $є$ економічний чинник. У країнах з обмеженими матеріальними ресурсами через брак обладнання та коштовність інгаляційних анестетиків спінальна анестезія найчастіше є методом вибору.

\section{СПИСОК ЛІТЕРАТУРИ}

Мельник ОП. Порівняльний аналіз видів комбінованої анестезії при лапароскопічній Bajwa SJS et al. Anaesthesia for laparoscopic surgery: General vs regional anaesthesia.

Hajong R, et al. Laparoscopic cholecystectomy under epidural anesthesia. N Am J Kranke $P$, et al. Continuous intravenous perioperative lidocaine infusion for postoperative

Sabry $M$, et al. Continuous spinal anesthesia for elderly patients with cardiomyopathy undergoin
$535-540$.

6. Uzman S, et al. Combined spinal-epidural anesthesia in laparoscopic appendectomy. Ann Surg Treat Res. 2017; 92: 208-213.

Бігняк П.І. ${ }^{2}$, ГОМон М.Л. ${ }^{1}$, Дацюк O.І. ${ }^{1}$

\title{
ПОРУШЕННЯ ЕЛЕКТРОЛІТНОГО БАЛАНСУ ПРИ ТРАДИЦІЙНІЙ ПЕРЕДОПЕРАЦІЙНІЙ ПІДГОТОВЦІ ХІРУРГІЧНИХ ХВОРИХ
}

\section{АКТУАЛЬНІСТЬ}

Гострий дефіцит рідини та електролітів спричиняє дегідратацію, що створює несприятливий фон для перебігу післяопераційного періоду хірургічних хворих[1]. Корекція зазначених змін відновлює роботу клітинних насосів, зменшує внутрішньоклітинний ацидоз та забезпечує адекватне функціонування тканин, зокрема анаболізм і імунологічний захист. $[2,3]$. Саме тому дослідження та корекція водно-електролітного балансу $є$ обов'язковим компонентом периопераційної інтенсивної терапії хірургічних хворих та входить до Європейських протоколів ERAS (Enhanced Recovery After Surgery), де передопераційна волемічна підготовка та скорочення термінів голодування має важливе значення [4]. Тому дослідження даної проблеми $\epsilon$ актуальним.

\section{META РОБОТИ}

Дослідити клінічну значимість порушень електролітного балансу у хворих, що готуються до планового хірургічного втручання.

\section{МАТЕРІАЛИ I МЕТОДИ}

Обстежено 39 планових пацієнтів хірургічного відділення Старокостянтинівської центральної районної лікарні, що отримували «традиційну» передопераційну підготовку. Вона включала припинення харчування ввечері напередодні оперативного втручання, підготовку кишківника. Стан порушення електролітного обміну (калію, натрію, хлору, рівня глюкози) оцінювали лабораторним шляхом на базі лабораторії INVIVO (TOB «Малікс МЕД»). Також оцінювались показники гемодинаміки, діурезу, об'єм і якість інфузійної терапії. Дослідження проводили за добу до оперативного втручання, перед операцією та після неї через 8 та 24 години. Оцінювали також термін відновлення перистальтики кишківника.

\section{ральна районна лікарня²}

\section{РЕЗУЛЬТАТИ}

Різноманітні порушення водно-електролітного балансу спостерігались у $67 \%$ досліджуваних, зокрема: гіпокаліємія у 14 пацієнтів, гіпонатріємія у 18 пацієнтів; гіпернатрійемія у 11пацієнтів, гіпохлоремія у 7 пацієнтів. Всім пацієнтам на другу добу виконане оперативне втручання. В післяопераційному періоді спостерігалось зростання показників калію та натрію до меж фізіологічної норми, стресової гіперглікемії не спостерігалось.

Коливання гемодинаміки на другу добу мало тенденцію до нижніх меж норми, що корелювало зі зниженням діурезу. Відновлення перистальтики відмічено на $2,3 \pm$ $\pm 0,2$ добу. Слід відзначити наявність відчуття спраги у $86 \%$ пацієнтів на 2 добу післяопераційного періоду.

\section{ВИСНОВКИ}

1. Переважна більшість пацієнтів, що готувались до оперативного втручання традиційним методом, мають порушення електролітного балансу, які потребують корекції.

2. Відчуття спраги в післяопераційному періоді $є$ одним iз статистично значимих критеріїв оцінки порушень водно-електролітного балансу хірургічних хворих.

3. Доцільно провести більш глибокі дослідження з більшою вибіркою пацієнтів, що дозволить оптимізувати водноелектролітний стан хворих в перед та післяопераційному періоді.

\section{СПИСОК ЛІТЕРАТУРИ}

Петрушенко В.В., Рикало Н.А., Рауикіс В.А. Порушення водно-електролітного обміну: регулячія та компенсаторні механізми. Клінічні та експериментальні
дослідненн.//2013: 1: 299-301. Попутников Д.М., Меленчук Е.В., Висмонт Ф.И. Нарушения водно-электролитного обмена (патофизиологические аспекты).,Учебно-методическое пособие. Минск:БГМУ// 2011: 37.

Крамарьов С.О. (2017). Сучасні підходи до лікування зневоднення в дітей та дорослих./ Актуальна інсектологія.// 2017: T.5, 5: 205-208

4. Черній B.I., Євсеева В.В. Перспективи застосування протоколів ERAS у баріатричній хірургіï.Pain, anesthesia \& intensive care/ 2018; 82(1): 29-34.

УДК: 616.8-009.836:617-089

\section{Бодулєв О.Ю., Шкурупій Д.А. МЕТОДИ СУБ'ЄКТИВНОЇ ОЦІНКИ ЯКОСТІ СНУ У ХВОРИХ В ПЕРИОПЕРАЦІЙНОМУ ПЕРІОДІ}

\author{
ВДНЗ України «Українська медична стоматологічна академія» м. Полтава, Україна
}

\section{АКТУАЛЬНІСТЬ ПРОБЛЕМИ}

Порушення сну в периопераційному періоді клінічно важко оцінити достовірно, а їх об'єктивізація шляхом полісомно-графії $\epsilon$ малодоступною у рутинній практиці, тому вони часто залишаються поза увагою медичного персоналу [1].

\footnotetext{
Бігняк П.І., Гомон М.Л., Дацюк О.І., 2018

- Бодулєв О.Ю., Шкурупій Д.А., 2018
}

Мета роботи: обгрунтування вибору засобів діагностики постопераційної диссомнії на основі аналізу літературних джерел.

\section{МАТЕРІАЛИ ТА МЕТОДИ}

Проведено аналіз баз даних Cochrane Library, Medline, Scopus, Pubmed, за ключовими словами: Sleep 
MATERIALS OF THE CONGRESS OF ANAESTHESIOLOGISTS OF UKRAINE September 13-15, 2018

Disturbance, Insomnia, Perioperative, OSA, Questionnaire.

\section{РЕЗУЛЬТАТИ}

Виявлено 67 досліджень щодо застосування у хворих в периопераційному періоді шкал порушень сну. Серед них 53 оцінювали ризики розвитку синдрому сонного апное, 14 - ступінь виразності безсоння.

Для прогнозування сонного апное дослідниками використовувались: Берлінський опитувальник, шкали денної сонливості Епворт, P-SAP, OSA50, STOP-BANG, DESOSA [2-4]. Остання виявилась найбільш чутливою серед запропонованих шкал.

Для визначення тяжкості інсомнії використовуються Афінська шкала безсоння (AIS), Insomnia Severity Index (ISI), Richards-Campbell Sleep Questionnaire (RCSQ), шкали сонливості Епворт, Verran-Snyder-Halpern Sleep Scale, Subjective Sleep Quality Questionnaire, Піттсбурзький опитувальник індексу якості сну $[5,6]$. Найчастіше застосовуються AIS, ISI та RCSQ, проте порівняльні дослідження цих шкал для периопераційних хворих відсутні.

\section{PAIN, ANAESTIHESIA \& INTENSIVE CARE WB $201 \%$}

\section{ВИСНОВКИ}

Для комплексної суб'єктивної оцінки сну в периопераційному періоді доцільно застосовувати комбінації шкал DES-OSA з AIS, ISI або RCSQ. Потрібна оцінка валідності шкал AIS, ISI та RCSQ для даної популяції хворих.

\section{СПИСОК ЛІТЕРАТУРИ}

1. LaBarbera V. Central Disorders of Hypersomnolence, Restless Legs Syndrome. and Surgery With General Anesthesia: Patient Perceptions./LaBarbera V, Garcha PS, Bliwise DL,et al.//Front Hum Neurosci. 2018; 12: 99.

2. Nagappa M, Liao P, Wong J, et al.Validation of the STOP-Bang Questionnaire as a Screening Tool for Obstructive Sleep Apnea among Different Populations:
A Systematic Review and Meta-Analysis. PLoS One. 2015; 10(12): e0143697.

3. Amra B, Rahmati B, Soltaninejad F, Feizi A. Screening Questionnaires for Obstructive Sleep Apnea: An Updated Systematic Review. Oman Medical Journal. 2018; 33(3): 184-192.

4. Deflandre E, Piette N, Bonhomme V, Degey S, Deflandre E. Comparison of clinical scores in their ability to detect hypoxemic severe OSA patients. PLoS One. 2018; 13(5): e0196270.

5. Humphries JD. Sleep Disturbance And The Immunological Acute Phase Response In Hospitalized Post-Operative Adults. Wayne State University Dissertations. 2017; 1710 .

6. Navarro-Garcha MБ, Alegre C, Martinez-Oroz A, et al. Quality of sleep in patients undergoing cardiac surgery during the postoperative period in intensive care. Enfermerna Intensiva. 2017; 28(3): 114-124.

\title{
Вигонюк А.В., Гончарук О.С., Гомон М.Л., Косеченко Н.Ю., Маслій В.А. ОСОБЛИВОСТІ ФОРМУВАННЯ БОЛЬОВОЇ РЕАКЦІЇ В ПІСЛЯОПЕРАЦІЙНОМУ ПЕРІОДІ ПРИ ВИКОРИСТАННІ ЗАГАЛЬНОГО ЗНЕБОЛЮВАННЯ
}

\author{
Вінницький національний медичний університет ім. М.І.Пирогова.
}

\section{АКТУАЛЬНІСТЬ}

Достатньо розповсюдженою теорією післяопераційного болю є трактування його $з$ позиції трансдукції, трансмісії, модуляції, перцепції нервового імпульсу [1]. Очевидно дана теорія $є$ більше теоретичною і відображає наші знання 70-х років попереднього століття. На цій основі мало реальних методів оцінки впливу кожного перерахованого компонента на формування та вираженість больового синдрому в клінічній практиці. Відповідно відсутні патогенетично обгрунтовані і модульовані методи впливу на різного характеру больові синдроми. Так, наприклад, незалежно від характеру хірургічного втручання середньої травматичності в післяопераційному періоді пропонуються як нестероїдні протизапальні препарати (часто їх комбінація), так і епідуральна аналгезія, так і центральна аналгезія за допомогою наркотичних аналгетиків $[2,3,4]$. Це свідчить, що патогенетично конкретизованих методик знеболювання обмаль. Саме тому відсоток пацієнтів, які в різні проміжки післяопераційного періоду відчувають біль середньої інтенсивності в більшості клінік сягає $50 \%$ і більше. Це є причиною постійного вдосконалення протоколів ERAS (Enhanced Recovery After Surgery), де післяопераційне знеболювання має важливе значення [3]. Тому дослідження даної проблеми $\epsilon$ актуальним.

\section{META РОБОТИ}

Дослідити динаміку зміни порогу больової чутливост при використанні загальної анестезії різного характеру перебігу.

\section{МАТЕРІАЛИ І МЕТОДИ}

Проведено скринінг 108 хворих, які перенесли середньої травматичності хірургічні втручання під загальною анестезією в Вінницькій ОКЛ ім. М.І.Пирогова та Вінницькій ОДКЛ. Пацієнти поділені на групи: 72 хворих 3 епізодами больового синдрому середньої і високої інтенсивності за шкалою NRS (Numerical Rating Scal) в період 5 післяопераційних днів та 36 хворих з больовим синдромом малої інтенсивності. Серед отриманих груп досліджена зміна порогу больової чутливості NF (нейрофізіологічним методом), гемодинамічні показники
(ГДП), рівень кортизолу та глюкози крові, дози використаних наркотичних та ненаркотичних аналгетиків. В отриманих групах хворі рандомізовані за віком та статтю.

\section{РЕЗУЛЬТАТИ}

Методами статистичного аналізу виявлено найбільшу кореляційну залежність в групі 372 пацієнтів між больовим синдромом середньої та високої інтенсивності за шкалою NRS і зміною порогу больової чутливості. При цьому відмічена прямопропорційна залежність між вираженістю больового синдрому та індексом коливання порогу больової чутливості. Аналіз гемодинамічних коливань, лабораторних показників, доз аналгетиків носили лінійну залежність 3 вираженістю больового синдрому в структурі групи. В групі 336 чоловік коливання порогу больової чутливості носило невірогідний, однак обернено пропорційний характер. Вірогідних коливань ГДП, лабораторних показників та доз аналгетиків в операційний та післяопераційний період не виявлено.

\section{ВИСНОВКИ}

Формування вираженого больового синдрому першочергово залежить від коливання порогу больової чутливості, як наслідку нерівномірного знеболюючого ефекту в більшій мірі, ніж від самої методики знеболювання.

\section{СПИСОК ЛІТЕРАТУРИ}

Fitzgerald $M$. The spread of sensitization of polymodal nociceptors in the rabbit from nearby injury and by antidromic nerve stimulation./ $J$.

2. Завгородний А.А., Гриценко С.Н. Продленная послеоперачионная энидуральная аналгезия у больных с опухолями толстого кишеч-

3. Ліпич О.П., Лісещький В.А. Чи залежить якість відновлення перистальтики кищечника від знеболювання? /Гострі та невідкладні стани у практиці лікаря.// 2017; 51-52.

4. Мазур А.П., Сидюк О.Є. Післяоперачійна аналгезія у паиієнтів з езофагектомією./ Гострі та невідкладні стани у практиці лікаря.// 2017; 57.

5. Черній B.I., Євсеева В.В. Перспективи застосування протоколів $82(1): 29-34$ 


\title{
Георгіяни М.А., Корсунов В.А., Столяров К.Є., Пороша Н.С., Зубко В.В. СТАН ЦЕРЕБРАЛЬНОЇ ГЕМОДИНАМІКИ ТА МОЖЛИВОСТІ ЙОГО ПОКРАЩЕННЯ ПРИ ТЯЖКИХ ФОРМАХ НЕЙРОІНФЕКЦІЙ У ДІТЕЙ
}

\author{
Харківська медична академя післядипломної освіти
}

\section{АКТУАЛЬНІСТЬ ПРОБЛЕМИ}

Незалежно від етіології та топіки ураження центральної нервової системи, менінгіти та енцефаліти є захворюваннями, які несуть безпосередню загрозу життю. Одним із самих небезпечних ускладнень цих захворювань $\epsilon$ розлади церебральної гемодинаміки, які тісно повјязані 3 інтракраніальною гіпертензією. Їх діагностика та інтенсивна терапія є вкрай ускладненою через обмеженість неінвазивних методів моніторингу.

\section{META РОБОТИ}

Дослідити можливості транскраніальної допплерографії по середньо-мозковим артеріям для оцінки стану мозкового кровообігу при тяжких формах нейроінфекцій у дітей.

\section{МАТЕРІАЛИ ТА МЕТОДИ}

Протягом 2015-2018 років нами було проведено обстеження 48 дітей віком від 2 місяців до 17 років 3 інфекціями центральної нервової системи, яким проводилося лікування у відділенні анестезіології та інтенсивної терапії КЗОЗ ХОДІКЛ. Всім дітям здійснювалося ультразвукове допплерівське дослідження кровоплину по середньомозковоим артеріям датчиком 3 фазованою решіткою за допомогою сканеру «Ultima PA» з вимірюванням його максимальної та мінімальної швидкості та розрахунком середньої швидкості, пульсаційного індексу (PI) та індексу резистентності (IR), церебрального перфузійного тиску (еСРP), тиску нульового потоку (ZFP).

\section{РЕЗУЛЬТАТИ}

Отримані результати свідчать про наявність значних та різноманітних розладів коровобігу по середньомозковоим артеріям. Серед них спостерігалося збільшення або зменшення максимальної та мінімальної швидкості кровоплину, асимметрія кровоплину, вазоспазм, збільшення пульсаційного індексу. У хворих з PI понад 1,3 у.о. відзначалися найменші показники еСРP та ZFP, нижча оцінка глибини коми за шкалою Glasgow у педіатричній модифікації. Отже, збільшення РI може бути доступним неінвазивним критерієм зниження церебральної перфузії через збільшення внутрішньочерепного тиску.

\section{висновки}

1. Допплерографія церебрального кровообігу по середньо-мозковим артеріям $є$ неінвазивним та достаньо інформативним методом його оцінки.

2. Отримані дані дають підставу для диференційованої корекції розладів церебральної гемодинаміки під час інтенсивної терапії.

\section{СПИСОК ЛІТЕРАТУРИ}

A Review of Non-Invasive Methods of Monitoring Intracranial Pressure / D. Asiedua,

Transcranial Doppler Ultrasound: A Review of the Physical Principles and Major Applications in Critical Care / J. Naqvi, K. Yap, G. Ahmad [et al.] // International

3. A noninvasive estimation of cerebral perfusion pressure using critical closing pressure. P. $638-648$.

\section{Георгіяни М.А., Корсунов В.А., Столяров К.Є., Пороша Н.С., Зубко В.В. МЕНІНГОКОКОВА ІНФЕКЦІЯ У ДІТЕЙ. МИНУЛЕ ТА МАЙБУТНЄ IНТЕНСИВНОÏ ТЕРАПIÏ}

\section{Харківська медична академя післядипломної освіти}

\section{АКТУАЛЬНІСТЬ ПРОБЛЕМИ}

В Україні серед дітей щорічно реєструється 550 випадків менінгококової інфекції (MI). Показник летальності у 2004-2008 рр. коливався у межах $12-16 \%$, але у окремих регіонах країни він сягав 20-60\%.

\section{META РОБОТИ}

Провести аналіз сучасних напрямків прогнозування та інтенсивної терапії (IT) тяжких та блискавичних форм MI у дітей.

\section{МАТЕРІАЛИ ТА МЕТОДИ}

Протягом 2008-2014 років нами було проведено обстеження 11 дітей середнім віком $34,9 \pm 8,5$ міс. 3 тяжкими та блискавичними формами МI. До контрольної групи увійшла 21 здорова дитина середнім

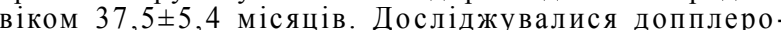
графічні показники центральної та периферичної (ниркової, печінкової, мезентеріальної) гемодинаміки за допомогою УЗ-сканеру «Ultima PA». У хворих на MI визначалися показники неінвазивного серцевого викиду (монітор Vismo Nichon Conden), кислотноосновного стану, кисневого транспорту, лактат крові, глюкоза, креатинін, ендотелін, оксид азоту, С-реактивний протеїн плазми.

\section{РЕЗУЛЬТАТИ}

Було показано, що у хворих з тяжким перебігом MI спостерігаються достовірно нижчи показники серцевого викиду, середнього аретеріального тиску, фракції викиду лівого шлуночка (ЛШ). Також спостерігається декомпенсований метаболічний лактат-ацидоз, ознаки гострого пошкодження нирок. У хворих на МІ ми спостерігали достовірне зростання систолічних швидкостей кровоплину у мезентеріальній, пенчінковій артерії та верхній порожнистій вені, а також зростання пульсаційного індексу магістральних ниркових вен. Спостерігалися тісні кореляційні зв язки між показниками органного кровообігу та вмістом вазоактивних медіаторов і функціональним станом органів. На підставі аналізу сучасних літературних джерел та результатів власного досвіду, зроблено припущення про важливе прогностичне значення зниження систолічної функції ЛШ у хворих на MI. 3 урахуванням отриманих даних запропоноване використання вазодилятаторів - нітратів для IT менінгококового септичного шоку з низькою продуктивністю серця та вираженими розладами периферичної перфузії.

\section{вИСНОВКИ}

1. МІ $є$ важливим чинником септичного шоку у дітей $\mathrm{i}$ супроводжується високою летальністю. 
2. Зниження систолічної функції ЛШ та порушення органного кровоплину $є$ факторами поганого перебігу, які ассоціюються із зростанням вмісту ендотеліну та відносною нестачею оксиду азоту сироватки.

3. IT MI має враховувати систолічну дисфункцію ЛШ, що потребує обережного підходу до інфузії, призначення інотропів та, за необхідності, нітратів.

\section{СПИСОК ЛІТЕРАТУРИ}

1. Maoldomhnaigh $C$. Invasive meningococcal disease in children in Ireland, 2001-2011/C.Maoldomhnaigh, R.Drew, P.Gavin // Arch Dis Child. - 2016. - Vol. 101. - P.1125-1129.

2. Nadel S. Treatment of Meningococcal Disease. Review article. I S. Nadel // J.of Adolescent Health. - 2016. - Vol. 59.

P. $21-28$

Горкавый Е.А. Лесной И.И.

\title{
СРАВНЕНИЕ МЕТОДОВ ПЕРИОПЕРАЦИОННОГО ОБЕЗБОЛИВАНИЯ ПРИ ХИРУРГИЧЕСКОМ ЛЕЧЕНИИ РАКА ПРЯМОЙ КИШКИ
}

\author{
Национальный институт рака, отдел анестезиологии и интенсивной терапии, Киев, Украина,
} e-mail : yevgen.gorkavyy@gmail.com

\section{АКТУАЛЬНОСТЬ ТЕМЫ}

В 2015 г. диагностировано более 7500 случаев рака прямой кишки (РПК) в Украине. 32\% пациентов проводят комбинированное лечение - сочетание хирургического вмешательства с предоперационной химиолучевой терапией. Смертность до года достигает $30 \%$, составляет 10 на 100000 населения. Несмотря на усовершенствование методов обезболивания, $59 \%$ пацентов ощущают боль от умеренной до сильной в послеоперационном (п/о) периоде, поэтому адекватное обезболивание и быстрое восстановление пациентов после хирургического лечения РПК остается актуальной.

Цель исследования: изучить влияние методов периоперационного обезболивания (ПО) на показатели гемодинамики, гликемию, адекватность аналгезии при хирургическом лечении РПК.

\section{МАТЕРИАЛЫ И МЕТОДЬ}

52 пациента с РПК, $\mathrm{T}_{2-3} \mathrm{~N}_{1-2} \mathrm{M}_{0}$ в возрасте $52 \pm 5,3$ лет, ASA II-III. Гр. A: $18^{2-3}$ больных, оперированных под эндотрахеальной ингаляционной (севоран) анестезией (ИА) в сочетании с эпидуральной аналгезией (ЭА) наропином 0,2\% с фентанилом. Гр. Б: 17 больным применялась тотальная внутривенная анестезия (ТВВАпропофол с фентанилом) с ЭА наропином 0,2\%. Гр. В: 17 пациентов, оперированных под ТВВА (пропофол с фентанилом). П/о обезболивание в Гр. А ЭА смесью наропина $0,2 \%$, фентанила 2,5 мкг/мл и адреналина 2 мкг/мл посредством эластической инфузионной помпы в сочетании с парентеральными нестероидными противовоспалительными препаратами (НПВП) и парацетамолом (П). Гр. Б ЭА наропином 0,2 \% в сочетании с контролируемой пациентом аналгезией (КПА) фентанилом 10 мкг/мл в/в с парентеральными НПВП и П. Гр. В включала введение омнопона и аналгина на регулярной основе. Периоперационный мониторинг включал оценку АДсред, ЧСС, уровень гликемии до, в конце операции, на 3 и 10 сутки п/о. Оценивали боль по шкале ВАШ первые 3 суток п/о.

\section{РЕЗУЛЬТАТЬ}

Результаты показали, что потребность в фентаниле и мышечных релаксантах меньше в Гр. А и Гр. Б в сравнении с Гр. В, но статистически значимых различий не было достигнуто $(p=0,0561)$. Снижение среднего АД во всех группах после интубации трахеи было кратковременным и не превышало $20 \%-25 \%$ от исходных значений. Отмечено снижение АДсред. на $7,5 \%$ в Гр. А и Гр. Б сравнении с Гр. В, но не снижалось ниже 60 мм.рт.ст. ЧСС оставалась стабильной на протяжении всего периоперационного периода во всех группах. Гликемия оставалась в норме на всех этапах исследования в Гр. А и Гр. Б, тогда как в Гр. В увеличилась на $50 \%$ в конце операции и было двухкратное увеличение на $3 \mathrm{c}$. п/о с нормализацией к $10 \mathrm{c}$. п/о. Интенсивность боли по шкале ВАШ в Гр. А и Гр. Б в два раза ниже в сравнении с Гр. В в послеоперационном периоде.

\section{выводы}

1. Мультимодальный подход с ИА и ТВВА в сочетании с ЭА и парентеральными НПВП и П, безопасен и более эффективен для защиты пациента от хирургического стресса в сравнении с ТВВА без ЭА.

2. Метод ЭА в сочетании с КПА фентанилом и парентеральными НПВП и П, безопасен и более эффективен для п/о обезболивания в сравнении с традиционными опиоидными аналгетиками при хирургическом лечении РПК.

\section{СПИСОК ЛИТЕРАТУРЫ}

1. Национальный канцер реестр Украины, 2015

2. Kehlet H,Dahl JB. The Lancet,Vol 362, 2003.

3. Guidelines for Perioperative Care in Elective Rectal Surgery.ERAS Guidelines for Perioperative
Society Recommendations.

4. Acute Pain Management, 2015

\section{Гриценко С.Н., Мизиненко И.В.}

\section{ИНТЕНСИВНАЯ ТЕРАПИЯ ТРОМБОЭМБОЛИИ ЛЕГОЧНОЙ АРТЕРИИ}

ГУ «Запорожская медицинская академия последипломного образования МОЗ Украины», Запорожье

\section{АКТУАЛЬНОСТЬ}

Тромбоэмболия легочной артерии (ТЭЛА) распространенное заболевание и является одной из основных причин внезапной смерти и инвалидности в мире. Частота ТЭЛА в Украине около 50 тыс. в год, умирает более 10 тыс. больных [1].

\section{ЦЕЛЬ ИССЛЕДОВАНИЯ}

Улучшить результаты интенсивной терапии ТЭЛА.
МАТЕРИАЛ И МЕТОДЫ

В исследование включены 191 больной с диагнозом ТЭЛА, которые находились на лечении в отделении кардиореанимации Запорожской областной клинической больницы за период 2015-2017 годов.

Возраст колебался от 23 до 90 лет $(60,7 \pm 13,6)$. Для верификации диагноза применяли ангиопульмографию (АПГ) и мультиспиральную компьютерную томографию

\footnotetext{
Горкавый Е.А. Лесной И.И., 2018

- Гриценко С.Н., Мизиненко И.В., 2018
} 
с контрастным усилением (МСКТ). Для определения степени нарушения проходимости ветвей легочной артерии использовали ангиографический индекс эмболии, предложенный Miller G.A. при АПГ. При МСКТ использовали индекс эмболии, аналогичный индексу Miller с учетом количества, диаметра и степени нарушения проходимости сосудов. В соответствие с величиной индексов эмболии больные были разделены на три группы: 1-15 баллов (немассивная ТЭЛА) - 25 больных, 16-21 балл (субмассивная ТЭЛА) - 38 больных, 22 и более (массивная ТЭЛА) 128 больных.

\section{РЕЗУЛЬТАТЫ}

В зависимости от тяжести ТЭЛА применен дифференцированный подход к выбору тромболитической терапии При массивной и субмассивной ТЭЛА применяли альтеплазу или стрептокиназу, а при немассивной ТЭЛА гепаринотерапию. В группе массивной ТЭЛА признаки острой легочной гипертензии (увеличение диаметра легочных артерий и смещение межжелудочковой перегородки влево) наблюдали у 36 больных (28\%), что требовало применения препаратов, уменьшающих давление в легочном русле. В группе с субмассивной ТЭЛА легочную гипертензию наблюдали у $6 \%$ больных, в группе с немассивной ТЭЛА - у $3 \%$. В связи с противопоказаниями к ТЛТ, двум больным с массивной ТЭЛА выполняли открытую хирургическую легочную эмболэктомию. Позитивным считали снижение индексов эмболии до уровня менее 15 баллов или полный лизис тромбов, нормализацию артериального давления, показателя насыщение гемоглобина кислородом при дыхании воздухом, отсутствие одышки и снижение давления в легочной артерии до нормы или до уровня легочной гипертезии 1 ст. Летальность в отделении ИТ составила $12 \%$.

\section{выводы}

Дифференцированный подход позволяет выбрать метод лечения ТЭЛА в зависимости от тяжести заболевания: при массивной и субмассивной ТЭЛА обосновано применение ТЛТ, а при немассивной ТЭЛА - гепаринотерапия.

\section{СПИСОК ЛИТЕРАТУРЫ}

1. Тромбоэмболия легочной артерии / Ф.С. Глумчер, В.Г. Мишалов, А.С. Никоненко и др.; под ред. Ф.С. Глумчера, В.Г. Мималова, А.С. Никоненко, Б.М. Тодурова.- К.: Издатель Заславский А.Ю.,2016 524

\title{
Губанова О.В., Георгіяни А М. \\ ВИБІР АНЕСТЕЗІОЛОГІЧНОЇ ТАКТИКИ ПРИ ХІРУРГІЧНІЙ КОРЕКЦІЇ ВРОДЖЕНИХ ВАД НИЖНІХ КІНЦІВОК У ДІТЕЙ РАННЬОГО ВІКУ В ЗАЛЕЖНОСТІ ВІД КОМБОРБІДНОСТІ
}

\author{
Харківська медична академя післядипломної освіти
}

\section{ВСТУП}

На даний час не існує чіткої концепції щодо вибору методу анестезії у дітей з вродженними вадами опорно-рухового апарату з урахуванням коморбідної навантаженності [1-3].

\section{META}

Вибрати найбільш ефективний метод анестезії з метою мінімізації ризиків хірургічного лікування вродженних вад нижніх кінцівок у дітей раннього віку.

\section{МАТЕРІАЛИ ТА МЕТОДИ}

На базі ХОКТЛ обстежено 84 пацієнти віком від 6 міс до 3 років за ASA II-III, яким були виконані планові оперативні втручання 3 приводу вроджених вад нижніх кінцівок. Сформовано 3 групи пацієнтів, в залежності від обраного методу анестезії: I - загальна анестезія (3А) (n = 31); II - провідникова анестезія (ПА) $(\mathrm{n}=35)$; III - каудальна анестезія (КА) $(\mathrm{n}=18)$. У пацієнтів всіх груп проводилася оцінка об'єктивного статусу та аналіз навантаженості супутньою патологією. Оцінювали рівень сенсорного та моторного блоку, стан гемодинаміки, рівень післяопераційного болю за шкалою CHIPPS. Виявили особливості техніки виконання провідникової анестезії у дітей 3 вродженними вадами нижніх кінцівок.

\section{РЕЗУЛЬТАТИ}

ЗА проводилась 3 використанням великих доз опіоїдів, гіпнотиків та міорелаксантів для забезпечення адекватної анестезії. Після ЗА мало місце пролонговане відновлення свідомості, інтенсивний післяопераційний біль по CHIPPS більше 6 балів, що потребувало введення опіоїдів, інфузійної підтримки. Це все пролонгувало післяопераційне пробудження, час моніторингу в умовах відділення інтенсивної терапії, відстрочення відновлення звичайного режиму життя.
У пацієнтів після регіонарної анестезії у післяопераційному періоді був адекватний рівень свідомості, відсутня медикаментозна депресія дихання, використовувалися лише неопіоїдні аналгетики. Оцінка післяопераціиного анальгетичного ефекту показала, що діти групи (3А) потребували знеболення через $25,3 \pm$ $\pm 8,2$ хв, групи (ПА) через $136,0 \pm 26,2$ хв, групи (КА) через 53,0 $\pm 6,2$ хв. Діти після провідникової анестезії в середньому через 25,7 хв поверталися до батьків, у жодному з випадків не мали скарг (нудота, блювання, збудження і т.п), відновлювалося харчування в середньому через 30,5 хвилини, не було порушень свідомості, затримки сечевиделення . Ускладнень, пов'язаних 3 технікою регіональних блоків, не спостерігалося.

\section{ВИСНОВКИ}

Відмова від опіатів і міорелаксантів при проведенні регіонарних блокад в умовах виключення свідомості тільки гіпнотиком, відсутність болю та активність пацієнтів у післяопераційному періоді $є$ більш сприятливою тактикою у дітей 3 коморбідною патологією.

\section{СПИСОК ЛІТЕРАТУРИ}

1. Juhr, Martin. Regional anaesthesia in neonates, infants and children: Aneducational review/ European Journal of Anaesthesiology (EJA): May 2015 - Volume 32 - Issue 5 - p 289297

2. Suresh S, Ecoffey C, Bosenberg A, Lonnqvist PA. The European Society of Regional Anaesthesia and Pain Therapy/American Society of Regional Anesthesia and Pain Medicine Recommendations on Local Anesthetics and Adjuvants Dosage in Pedidations on Local Anesthetics and Adjuvants Dosage in Pedi-
atric Regional Anesthesia. Reg Anesth Pain Med. 2018 Feb; 43(2): $211-216$

3. Polaner DM Taenzer AH, Walker BJ et al Pediatric Regional Anesthesia Network (PRAN): a multiinstitutional study of the use and incidence of complications of pediatric regional anesthesia. Anesth.Analg 2012; 115:1353-1364. 
Гурін П.В.

\section{ВПЛИВ РОЗЧИНІВ ГІДРОКСИЕТИЛКРОХМАЛІВ НА КОАГУЛЯЦІЙНИЙ ГЕМОСТАЗ ПІД ЧАС КОРОНАРНОГО ШУНТУВАННЯ НА ПРАЦЮЮЧОМУ СЕРЦІ}

\section{ДУ "Національний інститут хірургії та трансплантології ім. О.О.Шалімова» НАМН України}

\section{АКТУАЛЬНІСТЬ}

Інфузійна терапія операцій коронарного шунтування (КШ) на працюючому серці включає в себе як колоїдні так кристалоїдні розчини. Колоїдні розчини переважають кристалоїдні в ступені збільшення серцевого викиду i, як наслідок, збільшенню доставки кисню органам і тканинам $[3,4]$. Розчини гідроксиетилкрохмалів (ГЕК) найчастіше використовуються серед інших колоїдних розчинів для корекції гіповолемії в периопераційному періоді $[5,6]$. Однак розчини ГЕК мають і ряд недоліків, які обмежують широке їх застосування. Серед них: вплив на систему гемостазу, збільшують ризик гострого пошкодження нирок і можуть потенціювати системну запальну відповідь [7]. Тому вибір оптимального інфузійного розчину під час КШ на працюючому серці вважається досі невирішеним питанням.

\section{META РОБОТИ}

Вивчити вплив колоїдних та кристалоїдних розчинів розчинів на систему коагуляційного гемостазу у пацієнтів, яким було виконано КШ на працюючому серці.

\section{МАТЕРІАЛИ ТА МЕТОДИ}

В основу дослідження покладений ретроспективний аналіз 40 історій хвороб пацієнтів, яким з січня по серпень 2018 року було виконане ізольоване КШ-3 на працюючому серці. Критеріями виключення пацієнтів із дослідження були: фракція викиду лівого шлуночку менша за 50 \%, початковий рівень креатиніну крові $>140$ мкмоль/л, рівень гемоглобіну $<120$ г/л, доопераційна коагулопатія, печінкова дисфункція (АЛТ > 40 ОД/л, АСТ > 40 ОД/л).

Пацієнти були розподілені на 2 рівні групи по 20 чоловік: 1-ша група - в інтраопераційному періоді застосовувався розчин ГЕК $130 / 0,4 ; 2$-га група (група порівняння) пацієнти, яким колоїдні розчини в інтраопераційному періоді не застосовувались.

Лабораторний контроль коагуляційного гемостазу включав в себе визначення протромбінового часу (ПЧ), протромбінового індексу (ПІ), міжнародного нормалізованого відношення (МНB), активованого часткового тромбопластинового часу (АЧТЧ), тромбоеластометрію (ТЕМ).

\section{РЕЗУЛЬТАТИ ТА ОБГОВОРЕННЯ}

Пацієнти досліджуваних груп не відрізнялись між собою за клінічними та лабораторними показниками перед проведенням оперативного втручання. Дослідження показників коагуляційного гемостазу проводили в інтра- та післяопераційному періоді. В середньому доза розчину ГЕК 130/0,4 $11,7 \pm 1,5$ мл/кг. Аналіз ТЕМ проводили після введення всієї дози колоїдного розчину і перед введення гепарину. В групі 1 показники ПЧ, ПІ та МНВ в кінці операції були достовірно нижчими, ніж у пацієнтів 2-ї групи. Подібні результати спостерігались і через 24 години після операції. Лише через 48 годин після операції показники коагуляційного гемостазу не відрізнялись між групами. Показник ТЕМ СТ
Таблиця 1. Показники коагуляційного гемостазу в периопераційному періоді

\begin{tabular}{l|c|c|c}
\hline \multicolumn{1}{c|}{ Показник } & $\begin{array}{c}\text { Група 1 } \\
\mathbf{N = 2 0 ,} \mathbf{M} \pm \mathbf{S D}\end{array}$ & $\begin{array}{c}\text { Група 3 } \\
\mathbf{N = 2 0 , ~ M \pm S D ~}\end{array}$ & $\mathbf{p}$ \\
\hline $\begin{array}{l}\text { СТ ехтет, сек } \\
\text { норма - 38-79 секу нд) }\end{array}$ & $102,1 \pm 15,4$ & $66,3 \pm 5$ & 0,0001 \\
\hline ПЧ кінець операції, сек & $20,6 \pm 3,8$ & $18,5 \pm 2$ & 0,04 \\
\hline ПЧ 24 години п/о, сек & $18,6 \pm 1,6$ & $17,3 \pm 1,7$ & 0,02 \\
\hline ПЧ 48 годин п/о, сек & $18,1 \pm 0,82$ & $17,7 \pm 1,4$ & 0,27 \\
\hline ПІ кінець операції, \% & $65,1 \pm 12,1$ & $78,4 \pm 7,7$ & 0,0002 \\
\hline ПІ 24 години п/о, \% & $73,5 \pm 6,7$ & $83,7 \pm 7,6$ & 0,0001 \\
\hline ПІ 48 годин п/о, \% & $81,1 \pm 4,3$ & $84,2 \pm 6,7$ & 0,08 \\
\hline МНВ кінець операції & $1,76 \pm 0,32$ & $1,55 \pm 0,24$ & 0,02 \\
\hline МНВ 24 години п/о & $1,58 \pm 0,28$ & $1,37 \pm 0,17$ & 0,006 \\
\hline МНВ 48 годин п/о & $1,37 \pm 0,19$ & $1,34 \pm 0,16$ & 0,59 \\
\hline
\end{tabular}

extem також був достовірно вищим в групі 1, що свідчило про вплив розчинів ГЕКу на коагуляційний гемостаз.

Інтраопераційна крововтрата була вищою у пацієнтів 1-ї групи $(615 \pm 191$ мл vs $438 \pm 62$ мл.; $p=0,0003)$, час знаходження у відділенні інтенсивної терапії (BIT) також був вищим у 1-ої групи пацієнтів (52 \pm год. vs $43,2 \pm 10$ год.; $\mathrm{p}=0,002)$.

\section{ВИСНОВКИ}

1. Використання розчинів ГЕК призводить до зміни показників коагуляційного гемостазу.

2. Тромбоеластометрія є ефективним методом діагностики порушень коагуляційного гемостазу.

3. Використання розчинів ГЕК збільшує периопераційну крововтрату та час перебування у BIT.

4. Під час планових оперативних втручань перевагу слід віддавати кристалоїдним розчинам в якості базових.

\section{СПИСОК ЛІТЕРАТУРИ}

1. Joosten A., Delaporte A., Ickx B., et al. Crystalloid versus Colloid for Intraoperative Goal-directed Fluid Therapy Using a Closed-loop System: A Randomized, Doubleblinded, Controlled Trial in Major Abdominal Surgery. Anesthesiology 2018 Jan;128(1):55-66.

2. Heminq N., Elatrous S., Jaber S., et al. Haemodynamic response to crystalloids or colloids in shock: an exploratory subgroup analysis of a randomised controlled trial. colloids in shock: an exploratory

3. Myburgh JA, Finfer S, Bellomo R, et al. Hydroxyethyl starch or saline for fluid resuscita tion in intensive care. $N$ Engl J Med, 2012;367: 1901-11.

Myburgh JA., Mythen MG. Resuscitation Fluids. N Engl J Med, 2013; 369:1243 -51.

5. Matharu NM, Butler LM, Rainger GE, et al. Mechanisms of the anti-inflammatory effects of hydroxyethyl starch demonstrated in a flow-based model of neutrophil recruitment by endothelial cells. Crit Care Med, 2008;36(5):1536-42.

\section{МОЗКОВА ТА РЕСПІРАТОРНА ДИСФУНКЦІЯ - ЯК ПРЕДИКТОРИ СИНДРОМУ ПОЛІОРГАННОЇ НЕДОСТАТНОСТІ ПРИ ВАЖКОМУ ГОСТРОМУ ПАНКРЕАТИТІ}

\section{АКТУАЛЬНІСТЬ ПРОБЛЕМИ}

У $20-30 \%$ хворих гострим панкреатитом (ГП) перебіг захворювання ускладнюється внаслідок раннього (токсичного) або пізнього (септичного) синдрому поліорганної недостатності (СПОН). Мозкова та респіраторна дисфункції в $70 \%$ випадків стають одними 3 перших симптомів СПОН [1].

\footnotetext{
Гурін П.В., 2018

○ Дачюк О.І., Гомон М.Л., Дацюк Л.В., 2018
} 


\section{МЕТА ДОСЛІДЖЕННЯ}

Визначення оптимальних методів профілактики та лікування СПОН у хворих 3 ГП в залежності від структури СПОН.

\section{МАТЕРІАЛИ ТА МЕТОДИ}

223 хворих 3 важким ГП були поділені на дві групи: контрольна - 145 хворих, які лікувались в $2012-2016$ рр., основна - 78 пацієнтів, яким в 2017 та 2018 рр. застосовувалась етапна індивідуалізована профілактика та лікування можливих ускладнень.

У 2016 р., з урахуванням сучасних рекомендацій [2, 3, 4], в нашій клініці були оптимізовані підходи до проведення інтенсивної терапії ГП. Лікувальний комплекс у пацієнтів основної групи включав: 1) панкреотропні антибактеріальні препарати (меропенеми, фторхінолони); 2) внутрішньоартеріальний доступ (в черевний стовбур) для проведення антибактеріальної та антисекреторної терапії; 3) рестриктивні режими інфузійної терапії; 4) парентеральне харчування багатомпонентними сумішами; 5) у випадку токсичної енцефалопатії - седація дексмедетомидином при необхідності поєднувалась з бензодиазепінами; 6) у випадках виникнення респіраторної дисфункції з виразною дихальною недостатністю, застосовувалась респіраторна підтримка в режимі SPAP або замісної ШВЛ.

\section{РЕЗУЛЬТАТИ}

В контрольній групі моноорганна дисфункція розвинулась у 37 хворих, у $108-\mathrm{CПОН,} \mathrm{зокрема,} \mathrm{частота} \mathrm{розвитку}$ респіраторної дисфункції склала $32,4 \%$, мозкової - 31,2\%, серцево - судинної -22,8\%, ниркової - $18,3 \%$, печінкової $11,4 \%$. Мультиваріантний регресивний аналіз показав, що незалежними факторами госпітальної летальності при важкому ГП є респіраторна дисфункція (співвідношення шансів (СШ) - 3,47; довірчий інтервал (ДІ) - 1,58 -7,63) та мозкова (СШ - 3,5; ДІ - 1,44 - 8,49) дисфукції.

Проведення комплексного патогенетичного лікування 3 урахуванням профілактичної направленості проти розвитку СПОН, сприяло зниженню частоти розвитку СПОН з 74,5\% в контрольній групі до $62,6 \%$ в основній групі $(\mathrm{p}=0,003)$ і ранньої летальності з 19,3\% до 13,9\% $(\mathrm{p}=0,043)$ відповідно, тоді як достовірного зниження частоти гнійно - септичних ускладнень та пізньої летальності виявлено не було.

\section{ВИСНОВКИ}

1. Формування СПОН погіршує прогноз ГП. Вірогідність летального результату важкого ГП зростає у випадках розвитку респіраторної i/або мозкової дисфункції.

2. Дотримання протоколу інтенсивної терапії з урахуванням профілактичної направленості проти розвитку СПОН достовірно знижує частоту його розвитку на $11,9 \%$ у ранній фазі ГП та рівня ранньої летальності на $5,4 \%$.

\section{СПИСОК ЛІТЕРАТУРИ}

1. Мальцева Л. О. Сепсис-асочійована енцефалопатія у формуванні синдрому поліорганної недостатності у салопатія у формуванні сепсисом і септиним шоком Л O Мальуева ᄀ. $B$ Базиленком Clinical Anesthesiology \& Intensive Care. - 2015. - № 2 (6.) - P. $91-97$.

2. Riker R.R., Shehabi Y., Bokesh P.M. et al. Dexmedetomidine vs midazolam for sedation of critically ill patients: a randomized trial // JAMA. - 2009. Clinical practice guideline: management of acute pancreatitis / J. A.
Greenberg, J. Hsu, M. Bawazeer [et al.] // Can J Surg. - 2016. - Vol. 59 , № 2. - P. 128-140.

4. Early management of acute pancreatitis: A review of the best evidence $S$ Stigliano, H Sternby, E de Madaria [et al.] // Dig Liver Dis. - 2017. Vol. 49, № 6. P. $585-594$.

УДК 616.1-072.2-089.5-007.43

\section{Дзюба Д.О. ${ }^{1}$, Верещагін С.В. ${ }^{2}$ \\ МОЖЛИВОСТІ ЗАСТОСУВАННЯ КАУДАЛЬНОÏ АНЕСТЕЗІЇ В РЕНТГЕНЕНДОВАСКУЛЯРНІЙ ХІРУРГІЇ}

\section{${ }^{1}$ ДУ «Національна медична академія післядипломної освіти ім. П.Л.Шупика»} ${ }^{2}$ КЗ КОР «Київська обласна клінічна лікарня», м. Київ

Через швидкий розвиток рентгенендоваскулярних методик питання анестезіологічної тактики залишаються відкритими. У нашій роботи ми застосовували каудальну анестезію (КА) як стратегію периопераційного захисту при ендоваскулярних втручаннях 3 приводу облітеруючого атеросклерозу нижніх кінцівок (OAC) та фіброміоми маткових артерій.

\section{META РОБОТИ}

Оптимізація периопераційної анестезіологічної тактики при балонопластиці судин нижніх кінцівок та емболізації маткових артерій (ЕМА) шляхом застосування КА розчином бупівакаїну та бупренорфіну.

\section{МАТЕРІАЛИ ТА МЕТОДИ}

Дослідження було розподілено на два масиви.

Перша частина включала 30 жінок, яких було рандомізовано розподілено на дві групи. Всім хворим виконували в плановому порядку ЕMA 3 приводу фіброміоми матки. Пацієнткам дослідної групи, на етапі підготовки до оперативного вручання, за 30 хвилин до операції виконували одноразово попереджувальну КА $0,125 \%$ бупівакаїном у поєднанні 3 0,12 мг бупренорфіну в об“ємі 40 мл (20 мл р-ну Лонгокаїну +20 мл розчину $0,9 \% \mathrm{NaCl})$.

Друга частина включала 40 пацієнтів, яких було рандомізовано розподілено на дві групи. Всім хворим виконували в плановому порядку балонопластику судин нижніх кінцівок при ОАС. Пацієнтам дослідної групи, на етапі підготовки до оперативного вручання, за 30 хвилин до операції виконували одноразово КА 0,125\% бупіва- каїном у поєднанні з 0,12 мг бупренорфіну в об'ємі 30 мл (15 мл p-ну Лонгокаїну + 15 мл розчину $0,9 \% \mathrm{NaCl}$ ).

Пацієнтам контрольної групи інтраопераційно проводи-лась аналгоседація р-ном Фентанілу у дозі 1,5-2 мкг/кг/год та р-ном Сибазону у дозі 10 мг.

Всі оперативні втручання були виконані в Київській обласній клінічній лікарні.

\section{РЕЗУЛЬТАТИ}

У пацієнтів обох когорт дослідження КА було достатньо для забезпечення інтраопераційного антиноцицептивного захисту.

У жінок після ЕМА в групі КА, рівень болю за ШБ у часових проміжках 3 першої по третю години після оперативного втручання достовірно був менше в три рази, аніж у жінок контрольної групи. Через 8 годин - в 2 рази.

Що до пацієнтів з ОАС, то слід зауважити, що інтраопераційно у $60 \%$ хворих контрольної групи додатково до аналгоседації вводився р-н Фентанілу у дозі $1-1,5$ мкг/кг. А через годину після операції рівень за ШБ був в 2 рази нижче в групі КА.

Серед ускладнень ЕА ми спостерігали нудоту у 7\% та шкірний свербіж у 3,5\% пацієнтів, що пов'язують 3 додаванням опіоїдних анальгетиків до розчину місцевого анестетику. 3 іншими складнощами при застосуванні методики КА місцевими анестетиками ми не зіткнулися.

\section{ВИСНОВКИ}

1. Застосування каудальної анестезії в рентгенендоваскулярній хірургії при емболізації маткових артерій та 
балонопластиці нижніх кінцівок є доцільним, за рахунок антиноцицептивних ефектів епідуральної анестезії.

2. Каудальна аналгезія розчином бупівакаїну (Лонгокаїну) 3 бупренорфіном $є$ не тільки високоефективним, але й достатньо безпечним методом післяопераційного знеболювання.

\section{СПИСОК ЛІТЕРАТУРИ}

1. Дзюба Д.О., С.М. Недашківський, О.М. Злочевський Варіанти періоперачійного знеболювання хворих із критичною ішемією нижніх кінцівок, що прооперовані методом ендоваскулярної балонопластики // Медицина неотложных состояний. - 2016 -№ 3(74). - С.72-74

Дзюба Д.О. ГА. Дзюба, О.М. Чир'сва. Вплие епідуральної анестезії при

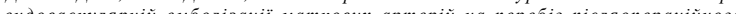

\title{
Дмитришина Є.О. \\ НОЗОКОМІАЛЬНІ ПНЕВМОНІЇ У ОПЕРОВАНИХ ХВОРИХ ТА ПОРАНЕНИХ
}

\author{
Українська військово-медична академія
}

\section{АКТУАЛЬНІСТЬ ПРОБЛЕМИ}

Нозокоміальна пневмонія (НП) є другою за частотою (після інфекцій сечових шляхів) внутрішньолікарняною інфекцією бактеріальної природи. Згідно даних Ю.І. Фещенка, 2013p., ГП розвиваються у $0,5-1 \%$ госпіталізованих хворих. Серед пацієнтів хірургічних відділень і палат інтенсивної терапії цей показник зростає до 15-20\% випадків, а серед хворих, яким проводиться ШВЛ - до $18-60 \%$.

Мета: визначення та вивчення чинників ризику розвитку нозокоміальних пневмоній, проаналізувати мікробіологічний спектр, визначити ефективні шляхи профілактики та антибактеріальної терапії у тяжкого контингенту хворих.

\section{МАТЕРІАЛИ ТА МЕТОДИ ДОСЛІДЖЕННЯ}

Робота базується на аналізі клінічних даних перебігу нозокоміальних пневмоній у 30 хворих та поранених хірургічного профілю, що знаходилися у ВРІТ НВМКЦ «ГВКГ» в період 2015 - 2017 роки.

\section{РЕЗУЛЬТАТИ ТА ЇХ ОБГОВОРЕННЯ}

Середня тривалість перебування хворого або пораненого у ВРІТ склала $11,9 \pm 8,5$ діб, а терміни виникнення НП становили $11,3 \pm 10,1$ діб.
Серед обстежених хворих з НП чоловіків було 93,3\%, а жінок $6,67 \%$. Із загального числа хворих поранені становили $-20 \%$ - усі чоловіки.

Згідно класифікації ВООЗ (2015р.) вікові показники у госпіталізованих хворих становили: до 45 років (молодий вік) - 33,3\%; від 46 до 59 років (середній вік) - 20\%; від 60 років (похилий вік) - 46,7\%.

46,2\% пацієнтів з НП потребували проведення подовженої ШВЛ. В залежності від тривалості проведення ШВЛ хворі були розподілені таким чином: від 24-48 годин 10\%; від 2 до 5 діб - 6,7 \%; більше 5 діб - 33,3 \%. Середня тривалість застосування ШВЛ дорівнювала 5,1 \pm 7,6 діб. Із загальної кількості хворих вентилятор - асоційовану пневмонію (ВАП) діагностовано у $36,6 \%$.

\section{ВИСНОВКИ}

Внаслідок аналізу отриманих даних ми виділили основні фактори та умови ризику НП: тяжка соматична патологія або важке поранення, клінічно значимі супутні захворювання, застосування ШВЛ $\geq 5$ діб, виснаження, порушення свідомості, тривала госпіталізація, якість антибіотикотерапії, похилий вік.

\section{Дорош О.І. ${ }^{1}$, Щуровська І.П.',2 \\ СЕПТИЧНІ УСКЛАДНЕННЯ У ХВОРОГО НА ГОСТРУ МІЄЛОЇДНУ ЛЕЙКЕМІЮ: КЛІНІЧНИЙ ВИПАДОК}

\author{
${ }^{1}$ КЗ ЛОР «Західноукраїнський спеціалізований дитячий медичний чентр», м. Львів (КЗ ЛОР \\ зУСДМЦ), Україна \\ ${ }^{2}$ Львівський національний медичний університет імені Данила Галицького, м. Львів, Україна
}

АКТУАЛЬНІСТЬ ТЕМИ

Септичні ускладнення у дітей, хворих на гостру лейкемію часто супроводжують поліхіміотерапію (ПХТ).

\section{МЕТА ДОСЛІДЖЕННЯ}

Аналіз ускладнень, які виникли у хворого на гостру мієлоїдну лейкемію (ГМЛ) під час ПХТ.

\section{МАТЕРІАЛИ ТА МЕТОДИ}

У пацієнта 3 рецидивом ГМЛ проаналізовано спектр ускладнень, які виникають під час ПХТ.

\section{РЕЗУЛЬТАТИ ТА ОБГОВОРЕННЯ}

Хлопчик, 8 р., хворий на ГМЛ, FАВ М5а, з реаранжацією MLL-гена, група високого ризику, 3 ініціальним ураженням ЦНС. Повний курс ПХТ AMLBFM'2003 проведено з 29.03.2010 до 28.09.2011. Через 5 р. 9 міс. розвинувся ізольований кістково-мозковий рецидив хвороби. Перед початком протирецидивної ПХТ імплантовано центральний венозний підшивний катетер Broviac. На фоні циторедуктивної префази розвинулась двобічна вогнищево-інтерстиціальна (пневмоцистна) пневмонія, ДН II ст., CCH II ст. (ефективність iv бісептолу $120 \mathrm{мг} / \mathrm{кг} 21$ день). Після стабілізації стану продовжено ПХТ, блок FLAG-IDA 3 праймінгом. Проводилась профілактика мікозу: віфенд per os. 7 мг/кг х 2. Після завершення блоку 3'явились: помірний стоматит, біль у мезо- та гіпогастрії, дизурія. УЗД - ознаки циститу з потовщенням задньої стінки сечового міхура; посів сечі без росту. У терапії: максіцин+метронідазол+віфенд. На 3-ю добу після завершення ПХТ відзначалась гіпертермія, біль у правій здухвинній ділянці, блювання, закреп, дефанс м'язів передньої черевної стінки, за даними УЗД - тифліт. Посів крові не дав росту, посів калу $-K l$. pneumonie, посів 3 ротової порожнини - Str. viridans, Enterococcus spp., Candida alb. У терапії: зівокс+меропенем+віфенд $i v$. Гарячка, клініка циститу та тифліту регресували на 3-ю добу. На 15-ий день після завершення ПХТ аплазія кровотворення, злоякісна гіпертермія, посилився стоматит. На Ехо-КГ, рентгенографії органів грудної клітки та комп'ютерній томографії - без змін. Тести: прокальцитонін, галактоманан, на CMV, EBV, HSV $1 \frac{1}{2}$, BIЛ (СНIД) - негативні. Посів крові та 3 ротової порожнини Candida alb. Застосовувались гранулоцитарні фактори росту, людський внутрішньовенний імуноглобулін, парентеральне живлення, гемокомпонентна, інфузійна терапія, антибактеріальна (АБТ): таргоцид+амікацин; інванз+дорібакс; піперацилін-тазобактам+тиментин, протигрибкова терапія (ПГТ): віфенд iv 7 мг/кг х 2,

\footnotetext{
- Дмитришина Є.О., 2018

- Дорош О.І., Щуровська І. П., 2018
} 
амфоліп. Стан без покращення. У клініці сепсис (Candida alb.), виразково-некротичний стоматит, ентроколіт, нефропатія, панкреатопатія, метаболічноелектролітні порушення. Продовжував АБТ тиментин+мепенем, ПГТ: флуконазол 12 мг/кг. Видалено венозний катетер Broviac на 12-у добу кандидемії та встановлено новий у v.subclavia, призначено мікамін 2 мг/кг, який знято на 6-у добу, оскільки утримувалась гіпертермія, у гемокультурі Candida alb. Температура тіла нормалізувалась через 2 дні після його усунення та 8-ий день введення мікаміну. На 11-ий день - регресував стоматит, із 13 -го дня - посіви крові не давали росту. Пацієнт перебуває у II ремісії ГМЛ після успішної алогенної трасплантації кісткового мозку.

\section{висновки}

У хворих на гемобластоз під час інтенсивної ПХТ виникають бактерійно-грибкові ускладнення. Важливою умовою лікування кандидемії є видалення у дитини центрального венозного катетера після першого позитивного результату культури крові. Мікамін володіє унікальним механізмом дії щодо Candida alb. та $є$ препаратом вибору для осіб із катетер-асоційованим сепсисом, викликаним Candida alb., резистентною до інших системних протигрибкових медикаментів.

\title{
Емельянова Е.А., Трегубенко С.А., Шелест Т.В.. Торяник Р.М., Бреус М.И. ПЕРВЫЙ СЛУЧАЙ УСПЕШНОГО ОПЕРАТИВНОГО ЛЕЧЕНИЯ СТЕНОЗА ТРАХЕИ В Г. КРИВОМ РОГЕ
}

\section{КУ “Криворожская городская клиническая больница №2» ДОС»}

В связи с увеличением длительности респираторной поддержки отмечается рост числа ранних и поздних посттрахеостомических осложнений, в частности, стенозов трахеи.

Приводится случай развития тяжелого стеноза трахеи у больного с тяжелой сочетанной травмой.

Больной К, 32 лет, доставлен в КУ «КГКБ №2» ДОР» 01.07.2017 г. через 1,5 часа после автодорожной травмы. При поступлении в больницу состояние крайне тяжелое. Диагноз: Сочетанная травма: ЗЧМТ: сотрясение головного мозга. ЗТГ: перелом ребер с 2-х сторон: 3-5, 8-9 справа и 3-5 слева, разрыв обоих легких, двухсторонний гемопневмоторакс, перелом грудины. Ушиб сердца с нарушением проводимости. ЗТЖ: гемоперитонеум, разрыв печени, разрыв селезенки, разрыв брыжейки толстой кишки, забрюшинная гематома, гематома мочевого пузыря. Разрыв лонного сочленения, перелом правой лонной, седалищной костей. Геморрагический шок III ст.

Выполнено оперативное вмешательство: Торакоцентез, дренирование обеих плевральных полостей. Лапаротомия: спленэктомия, ушивание печени, брыжейки толстой кишки, дренирование брюшной полости, ЧО АВФ костей таза. ПХО ран головы. Лечебно-диагностические мероприятия в операционной в течение 4,5 часов. Кровопотеря составила 3000 мл (54\% ОЦК). Инфузионно-трансфузионная терапия в объеме 4700 мл, из них СЗП 1150 мл, эритроцитов 932 мл.

На 3 сутки произведена открытая репозиция и МOC грудины, нижнесрединная поперечная трахеостомия. Длительность ИВЛ - 11 суток, трахеостомическая трубка удалена на 13 сутки. Из стационара выписан на 20 сутки по настоянию больного.

Повторно больной К. ургентно поступил в нашу больницу 11.10.17, через 3 месяца после травмы, из ЦРБ, где в течение
3 недель лечился по поводу бронхиальной астмы. Установлен диагноз: Посттрахеостомический рубцовый стеноз шейного отдела трахеи III ст.

От предложенного оперативного лечения в г. Киеве больной отказался. В связи с прогрессированием дыхательной недостаточности проведено оперативное лечение: цервикотомия, резекция трахеи. Резекция трахеи в нашей больнице была произведена впервые.

Интубация трахеи проведена при сохраненном сознании на спонтанном дыхании по бронхоскопу под местной анестезией. ЭТТ проведена за стеноз. После выделения трахеи произведена трахеотомия ниже стеноза и интубация правого главного бронха. Налажена однолегочная вентиляция. ЭТТ из трахеи удалена. Произведена резекция трахеи с последующей оротрахеальной интубацией, продолжена ИВЛ обоих легких. ЭТТ из правого бронха удалена через операционную рану. Трахея ушита. Санационная бронхоскопия. Длительность операции - 3ч 25 мин. Больной переведен в ОАИТ. Послеоперационный период без особенностей. Через сутки после операции выполнена ФБС, больной экстубирован и переведен в торакальное отделение. Выписан на 9 сутки после операции в удовлетворительном состоянии.

\section{ВЫводы}

1. Учитывая небольшую длительность нахождения трахеостомы, мы не можем однозначно объяснить причину развития стеноза трахеи.

2. Посттрахеостомический стеноз в нашей больнице после поперечной трахеотомии является крайне редким осложнением (1 случай за 10 лет).

3. Хирурги и анестезиологи нашей больницы приобрели первый опыт оперативного лечения и анестезиологического обеспечения у больных со стенозом трахеи.

\section{Емельянова Е.А., Шелест T.В. ОПЫТ ЛЕЧЕНИЯ ПОЛИТРАВМЫ В КРИВОРОЖСКОМ РЕГИОНЕ}

\author{
КУ «Криворожская городская клиническая больница №2» ДОС», ОАИТ
}

\section{АКТУАЛЬНОСТЬ}

Особенностью г. Кривого Рога является большое количество карьеров, шахт и горно-металлургических предприятий, являющихся зоной повышенного травматизма.

Цель работы: обобщение опыта оказания медицинской помощи больным с политравмой (ПТ) в Криворожском регионе.

\section{МАТЕРИАЛЫ И МЕТОДЫ}

На базе КУ «Криворожская городская клиническая больница №2» с 2005 года функционирует отделение ПТ на 30 коек. Ежегодно в этом отделении находится на лечении 700-800 больных, из них 26,3-33,7 \% пациентов в ОАИТ.

Взрослое население Криворожского госпитального округа составляет около 800 тыс. (город и прилегающие

\footnotetext{
- Емельянова Е.А., Трегубенко С.А., Шелест Т.В.. Торяник Р.М., Бреус М.И., 2018

- Емельянова Е.А., Шелест Т.В., 2018
} 
районы). Сроки доставки пациентов в пределах города составляют 15-30 минут, из сельских районов - от 40 до 80 минут. Иногда помощь оказывается в отдаленных городских или районных больницах с последующим переводом в отделение политравмы. В этих случаях часто встречается неправильная тактика оперативного вмешательства или анестезиологического пособия.

При открытии отделения ПТ ведение пострадавших осуществлялось бригадой врачей в составе: хирург, травматолог, нейрохирург, торакальный хирург, анестезиолог. С октября 2017 года, после реорганизации штатного расписания в ночное время в отделении ПТ дежурит только врач-травматолог. Врачи других специальностей привлекаются из профильных отделений. Это в ряде случаев приводит к недооценке прогностической тяжести повреждений.

Неотложная помощь в нашей больнице в течение 13 лет функционирования отделения ПТ оказывается в операционной, где одновременно выполняются диагностические, противошоковые мероприятия, неотложные операции и стабилизация переломов крупных костей, таза (при наличии металлоконструкций), скелетное вытяжение, гипсовая иммобилизация. Большую проблему составляет ограниченное количество в ургентной службе металлоконструкций ввиду их высокой стоимости. В связи с этим операции по окончательной стабилизации переломов проводятся через 2-5 суток после травмы.

В связи с крайне недостаточной обеспеченностью нашей больницы койками ИТ $(1: 57)$, из операционной в палату

интенсивной терапии общего профиля переводятся только крайне тяжелые пациенты, требующие протезирования витальных функций, которые составляют 1/3 больных, поступающих в больницу с ПТ.

\section{РЕЗУЛЬТАТЫ И ИХ ОБСУЖДЕНИЕ}

За последние 10 лет в больнице пролечено 7255 пострадавших с ПТ, из них 1970 (27,1\%) в ОАИТ. Пациенты с ПТ составляют $12,7 \%$ от всех больных ОАИТ. Средние сроки лечения в отделении ПТ 14,3 дней (в ОАИТ - 4,3), летальность $5,8 \%$ (в ОАИТ $16,0 \% /)$. Досуточная летальность за последние 3 года составляет $12,7 \%$.

Среди умерших преобладают больные с сочетанием тяжелой ЧМТ и торакальной травмы, а также пациенты с поражением трех и более анатомических зон

\section{ВЫВОды}

1. В настоящее время проблемой оказания квалифицированной помощи данному контингенту больных является кадровый вопрос.

2. Несмотря на накопленный опыт лечения больных с политравмой, в ургентной службе возникает дефицит специалистов, способных адекватно оценить прогностическую тяжесть повреждений поступающих больных с сочетанной травмой, особенно с преобладанием хирургической патологии.

3. Актуальной проблемой для нашей больницы является крайне ограниченное количество металлоконструкций в ургентной службе, что приводит к отсроченным операциям по стабилизации переломов.

\section{Емельянова Е.А., Шелест Т.В. РЕТРОСПЕКТИВНЫЙ АНАЛИЗ ОСЛОЖЕНИЙ ТРАХЕОСТОМИИ}

КУ «Криворожская городская клиническая больница №2» ДОС»

\section{АКТУАЛЬНОСТЬ ПРОБЛЕМЫ}

Увеличение количества критических больных, длительно находящихся на искусственной вентиляции легких (ИВЛ) привело к значительному увеличению проводимых трахеотомий и соответственно, увеличению выявляемых осложнений.

\section{ЦЕЛЬ}

Ретроспективный анализ ранних и поздних осложнений со стороны трахеи у трахеотомированных больных, длительно находящихся на ИВЛ

\section{МАТЕРИАЛЫ И МЕТОДЫ}

За период 2013-2018 года в нашей больнице в отделении интенсивной терапии пролечено 4206 больных, из них 1300 находилось на продленной ИВЛ. Было произведено 365 трахеостомий. В 350 (95,9\%) случаях проводилась нижнесрединная поперечная трахеотомия, у $15(4,1 \%)$ - дилятационная трахеотомия. Все операции трахеостомии проводились торакальными хирургами. Подобные операции выполнялись больным с тяжелой политравмой, ЧМТ, инсультами, миастенией, тяжелой лицевой травмой. Длительность ИВЛ составляла от 10 дней до 6 месяцев. Часть больных имела выраженные бульбарные нарушения. Контроль давления в манжете трахеотомической трубки не проводился из-за отсутствия необходимой аппаратуры. Бронхоскопии проводились 76\% трахеотомированных больных.

\section{РЕЗУЛЬТАТЫ}

Согласно литературным данным, частота осложнений составляет от $0,1 \%$ до $19 \%$ (по данным ряда авторов до $90 \%)$. При анализе ранних и поздних посттрахеостомических осложнений в нашей больнице выявлены следующие: стеноз трахеи, потребовавший оперативного лечения в отдаленном периоде - 1 $(0,27 \%)$, ранний вывих трахеотомической трубки - 1 $(0,27 \%)$, пневмоторакс $-2(0,54 \%)$, кровотечение из крупного сосуда-2 $(0,54 \%)$, эрозии трахеи - 49 $(13,4 \%)$. Воспалительные изменения в трахее наблюдались у всех больных при длительной ИВЛ.

\section{выводы}

1. На сегодняшний день подходы к профилактике и лечению постинтубационных и посттрахеостомических осложнений, рубцовых стенозов трахеи в частности, не имеют однозначного решения.

2. При лечении больных, длительно находящихся на ИВЛ, нужно постоянно помнить о возможности развития как ранних, так и поздних постинтубационных и посттрахеостомических осложнений.

3. Для уменьшения количества осложнений поперечная трахеотомия должна выполняться хирургом, имеющим опыт выполнения данной операции.

4. Всем больным с длительной ИВЛ необходимо проводить фибробронхоскопии перед и после удаления трахеостомической трубки.

\footnotetext{
- Емельянова Е.А., Шелест Т.В., 2018
} 


\title{
Йовенко И.А., Балака И.В., Коренюк Д.Е., Кобезкая О.Г. ИНФУЗИОННАЯ ТЕРАПИЯ КРИТИЧЕСКИХ СОСТОЯНИЙ: ПАТОФИЗИОЛОГИЧЕСКИЙ ПОДХОД
}

\author{
КУ «Днепропетровская областная клиническая больница им. И.И.Мечникова» ДОС
} КУ «Днепропетровский клинический онкологический диспансер» ДОС

Согласно современным данным клинической патофизиологии рекомендован четырехфазный подход к проведению инфузионной терапии при критических состояниях (концепция ROSE).

Фаза спасения - от 0 до 24 ч. Характеризуется высокой вероятностью гиповолемии, особенно при травме и тяжелом сепсисе. В качестве первой линии инфузионных сред рекомендуют сбалансированные солевые растворы, содержащие натрий в диапазоне 130-154 ммоль/л. Коллоиды можно рассматривать как жидкости второго ряда реанимации с учетом риска ОПП и коагулопатии. Исключением является необходимость как можно скорейшего переливания продуктов крови у пациентов с массивным кровотечением. Альбумин может иметь роль при сепсисе, но противопоказан при ЧМТ. Первоначальный болюс жидкости рекомендуют в дозе до 20-30 мл/кг. Но и более низкие дозы могут быть столь же эффективны. Рекомендуют раннее использование вазопрессоров (норадреналин, адреналин), чтобы уменьшить объем инфузионной терапии и улучшить перфузию органов путем увеличения венозного возврата, среднего АД и сердечного выброса.

Фаза оптимизации - между 24 и 72 ч. Частота гиповолемии существенно снижается. Объем инфузионной терапии до 5-15 мл/кг вводят при подозрении на гиповолемию. Большая часть любой в/в введенной жидкости может накапливаться в тканях (ятрогенный интерстициальный отек). Неблагоприятные последствия увеличения баланса жидкости, в частности, увеличение смертности и продление механической вентиляции продемонстрированы у пациентов с сепсисом и ОРДС.

Фаза стабилизации. Обычно происходит между 72 и 96 ч. Частота гиповолемии низкая, нет необходимости в инфузии дополнительной жидкости, кроме компенсации потерь и введения необходимых лекарств. Все еще нет четкого консенсуса в отношении объема при соблюдении стратегии рестриктивной инфузии. Показан ежедневный мониторинг массы тела, баланса жидкости и функции органов. Цель: нейтральный или отрицательный баланс жидкости. Рекомендовано до 25-30 мл/кг/день воды; около 1 ммоль/кг/день калия, натрия и хлорида и около 50-100 г/сут глюкозы для ограничения кетоза. Для пациентов, страдающих ожирением, регулируют объем жидкости на идеальный вес. Рассматривают назначение меньшего объема жидкости (20-25 мл/кг/день) для пациентов пожилого возраста, ослабленных, имеющих почечную или сердечную недостаточность.

Фаза деэскалации. Как правило, после 96 ч или при гемодинамической стабильности рекомендуют достичь отрицательного баланса жидкости путем либо ограничения внутривенного введения, либо увеличения удаления жидкости путем диуреза, либо ультрафильтрации.

Перспективной является стратегия персонализированной (индивидуализированной, персонифицированной) медицины (ПМ), основанной на анализе индивидуальных особенностей пациента (как всего организма, так и его отдельных тканей или клеток) и влияния генетических, внешнесредовых, региональных и пр. факторов. ПМ является областью интеграции современных биотехнологических подходов в медицинской практике, таких как фармакогеномика, фармакогенетика, метаболомика и др.

\section{СПИСОК ЛИТЕРАТУРЫ}

1. Personalised fluid resuscitation in the ICU: still a fluid concept? F. van Haren // Crit Care - 2017 -21(Suppl 3): 313. doi: 10.1186/s13054-017$1909-5$

2. Fluid resuscitation in acute medicine: what is the current situation? J. A. Myburgh // J Intern Med - 2015; 277: 58-68. doi: 10.1111/joim.12326 Intravenous Fluid Therapy for Adult patients at RCHT (2017). // https:/ /doclibrary-rcht.cornwall.nhs.uk/DocumentsLibrary/RoyalCornwallHospitalsTrust/Websites/Internet/OurServices/AZServices/L/LearningAndDevelopment/Induction/IVTherapyAdults.pdf

\section{Йовенко И.А., Кобеляцкий Ю.Ю., Царев А.В., Кузьмова Е.А., Мынка В.Ю., Селезнева У.В.}

\section{ОСТРАЯ ТРАВМАТИЧЕСКАЯ КОАГУЛОПАТИЯ: СТАНДАРТЫ ИТ}

\section{КУ «Днепропетровская областная клиническая больница им. И.И.Мечникова» доР ГУ «Днепропетровская медицинская академия» МЗУ Украины}

Неконтролируемое кровотечение является причиной 30 $40 \%$ смертей вследствие травмы. Около $10 \%$ этих смертей могут быть предотвратимы, а ИТ коагулопатии играет решающую роль. Травма в течение нескольких минут индуцирует острую эндогенную коагулопатию у $25 \%$ пациентов, независимо от действия других факторов (гипотермия, ацидоз, коагулопатия разведения), что четырехкратно увеличивает смертность.

Догоспитальный этап ИТ предполагает свести к минимуму время между тяжелой травмой, опасным кровотечением и доставкой пострадавших в специализированный травматологический центр (1B). Рекомендуют раннее использование кровеостанавливающих жгутов и тазовых бандажей (1B). Первоначальная реанимация пациента с травматическим кровотечением предполагает «допустимую гипотензию» с целевым средним АД 65 мм рт.ст. и/или систолическим АД 80-90 мм рт.ст. до достижения гемостаза (1C). Препаратом выбора для инфузии является изотонический кристаллоид (1А). Использование коллоидов ограничено из-за их неблагоприятного воздействия на гемостаз (2C). Клиническая оценка включает анатомо-физиологические данные, механизм травмы и реакцию пациента на первоначальную реанимацию (1C). Для обнаружения кровотечения рекомендуют раннюю и повторную визуализацию - компьютерная томография и УЗИ (1B). Лабораторный мониторинг включает: повторные измерения $\mathrm{Hb}$, лактата, $\mathrm{ScvO}_{2}$, гематокрита и избытка оснований (BE) для оценки перфузии, степени кровотечения, тяжести шока и эффективности заместительной терапии (1B). Рекомендуют ранний и повторный мониторинг коагуляции с использованием классических тестов (протромбиновое время (РТ), активированное частичное тромбопластиновое время (аРТТ), количество тромбоцитов и фибриноген (1А)) и/или вискоэластических тестов (TEG/ROTEM (1C)). Хирургическое лечение неотложно требуется пациентам с значительным кровотечением и сохраняющейся на фоне ИТ гемодинамической нестабильностью

\footnotetext{
○ Йовенко И.А., Балака И.В., Коренюк Д.Е., Кобезкая О.Г., 2018

- Йовенко И.А., Кобелячкий Ю.Ю., Царев А.В., Кузьмова Е.А., Мынка В.Ю., Селезнева У.В. , 2018
} 
(1А). Процедура экстренной торакотомии имеет четко ограниченные показания. Метод REBOA (реанимационная балонная окклюзия аорты) требует дальнейшей оценки. Интервенционная радиология может быть полезна при кровотечениях из таза, но требует соответствующей инфраструктуры. Используют одну из двух стратегий трансфузионной терапии: (1) плазма + эритроциты в соотношение не менее $1: 2$ (1B); или (2) фибриноген + эритроциты (1C). Трансфузию плазмы рекомендуют для поддержания РТ и аРТТ не $<1,5$ раза от нормы (1C). Концентрат фибриногена (криопреципитат) рекомендуют при уровне фибриногена $<1,5-2,0$ г/л (1C). Целевой уровень Нb составляет 70-90 г/л (1C), тромбоцитов $>50-100$ Ч $10 \%$ /л (1C). Введение транексамовой кислоты $(1 \Gamma+1$ г) необходимо как можно раньше у пациента с травмой и риском значительного кровотечения

(1А). Условия окружающей среды: избегание гипоксемии и ацидоза (1A), а также раннее применение мер по сокращению потерь тепла и поддержанию нормотермии (1C). Уровень ионизированного кальция должен поддерживаться в пределах нормальных диапазонов (1C). Управление безопасностью и качеством терапии требует использования методов лечения, основанных на доказательной медицине (1B).

\title{
СПИСОК ЛИТЕРАТУРЫ
}

1. Management of massive blood loss in trauma and traumainduced coagulopathy. M. Maegele // HemaSphere: Educational Updates in Hematology Book - 2018; 2(S2). doi: 10.1097/ HS 9.0000000000000093

2. The European guideline on management of major bleeding and coagulopathy following trauma: fourth edition. $R$. Rossaint coagulopathy following trauma: fourth edition. R. Rossaint,
$B$. Bouillon, V. Cerny, et al. // Critical Care - 2016-20:100. https:// doi org $110.1186 / s 13054-016-1265-x$

Каніковський О.Є., Осадчий А.В., Мосьондз В.В.

\section{ОБҐРУНТУВАННЯ ДЕТОКСИКАЦІЙНОЇ ТЕРАПІЇ ПРИ ГНІЙНО-НЕКРОТИЧНОМУ ВРАЖЕНІ ПАРАРЕКТАЛЬНОЇ ДІЛЯНКИ, НЕКРОТИЧНОМУ ФАСЦИЇТІ}

\author{
Вінницький національний медичний університет ім. М.І.Пирогова \\ Кафедра хірургії медичного факультету №2
}

\section{АКТУАЛЬНІСТЬ}

Гостра гнійна інфекція в структурі хірургічного стаціонару становить $14-28,5 \%$. Клінічний перебіг вирізняється особливою важкістю і супроводжується високою летальністю від 13,9\% до $30 \%$.

Некротичний фасциїт - прогресуючий некроз поверхневої фасції і підшкірної клітковини та поширення процесу по фасціальним просторам (швидкість поширення некрозу досягає 2,5 см в годину), 3 типовими симптомами системної запальної реакції (SIRS) та явищами системного ендотоксикозу поліорганної недостатності. Недооцінка важкості стану хворого i, як наслідок, відсутність адекватного комплексного лікування в значній мірі призводить до летальності пацієнта від септичного шоку.

\section{МЕТА ДОСЛІДЖЕННЯ}

Оцінити ефективність комплексного підходу до проведення детоксикаційної терапії у хворих на важкі форми гострого парапроктиту.

\section{МАТЕРІАЛИ ТА МЕТОДИ}

Проведено аналіз результатів лікування 178 хворих на гострий парапроктит, які знаходились на лікуванні в хірургічній клініці медичного факультету №2 ВНМУ в період з 2010 р. по 2018 рік. Чоловіків 112 (63\%), 66 жінок $(37 \%)$. Вік хворих складав від 18 до 82 років (середній вік 50 років). У $27(15,1 \%)$ діагностовано некротичне ураження фасцій промежини, передньої черевної стінки, стегон.

\section{РЕЗУЛЬТАТИ}

Передопераційну підготовку проводили в межах 4 годин до стабілізації показників гомеостазу. Хірургічні втручання під спінальним, а в важких випадках під інтубаційним знечуленням. Широкими розрізами розкривали гнійники, некротизовані та тканини із сумнівною життєздатністю видаляли до живих тканин. При виявленні запливів додаткові розтини апоневрозу та фасції для профілактики компартмент синдрому. Санацію просторів проводили озонованим розчином при використанні пульсуючого струменя системою Pulse lavage. Некректомія апаратом ультразвуково кавітації «Sonoca400» компанії «Soring». В якості робочого розчину використовували декаметоксин озонований розчин. Відмітили зменшення ексудації рани при використанні Уз-кавітації, а в поєднанні 3 активним дренування системою активної аспірації компанії «KCI» апаратом «ActiVac» скорочує терміни очищення рани (2-3 доба), поява грануляцій (4-6 доба) та активує власні репаративні процеси. Розробили проточно-промивні системи 3 активною аспірацією уражених параректальних клітковинних просторів.

Антибактеріальна терапія відповідно до рекомендацій "Sanford Guide" з врахуванням результатів бактеріологічних дослідження та визначенням чутливості до антибактеріальних препаратів

Інфузуя кристалоїдів в об'ємі 30 мл/кг, в співвідношенні 3 колоїдними розчинами 4-5:1 для відновлення водно-електролітних порушень. Знеболення досягали при комбінацій інфузії парацетамолу та в/м введення декскетопрофену, наркотичних анальгетиків.

Нейтралізацію дії ендотоксинів, підсилення функціональної активності лейкоцитів, покращення трофіки у місці запалення, стимуляції імунної системи та дії антибактеріальних препаратів досягли використанням гіпербаричної оксигенації, плазмаферезу, після відновлення протеінемії, та озонотерапія. Померло 5 хворих $(2 \%)$, а 3 фасциїтом (18\%). Середній ліжко день склав 14,5 днів при лікуванні важких форм гострого парапроктиту.

\section{ВИСНОВКИ}

1.Терміни передопераційної підготовки максимально скорочували.

2.Активна аспірація в поєднання 3 проточно-промивною системою забезпечує швидше очищення рани, контроль виділень та безболісність перев'язок.

3.Корекції сепсису проводилась комплексною детоксикаційною, антибактеріальною терапією в реанімаційному відділенні.

\section{СПИСОК ЛІТЕРАТУРИ}

1. Абдуллаев М.Ш., Мансурова А.Б. Острый парапроктит у больных сахарным диабетом (обзор литературы)//Колопроктология. - 2012. - № 1(39). - С.46-51.

2. Rieger U.M., Gugger C.Y., Farhadi J. et al. Prognostic factors in necrotizing fasciitis and myositis: analysis of 16 consecutive cases at a single institution in Switzerland // Ann. Plast. Surg. Vol. 58, №5. - P. 523-530.

3. Puvanendran R, Huey JCM, Pusapathy S. Necrotizing fasciitis. Canadian Family Physician. 2009. Vol. 55, N 10. P. 981 - 987.

○ Каніковський О.Є., Осадчий А.В., Мосьондз В.В., 2018 


\title{
Клєвакіна О.Ю., Анікін І.О. \\ КРИТЕРІЇ ЗАСТОСУВАННЯ НЕІНВАЗИВНОЇ ВЕНТИЛЯЦІЇ ЛЕГЕНЬ У ДОНОШЕНИХ НОВОНАРОДЖЕНИХ ІЗ ВАЖКОЮ ГІПОКСИЧНО-ІШЕМІЧНОЮ ЕНЦЕФАЛОПАТІЕЮ
}

\author{
Запорізький державний медичний університет
}

\section{АКТУАЛЬНІСТЬ ПРОБЛЕМИ}

Використання штучної вентиляції легень (ШВЛ) часто поєднується з важкими ускладненнями і віддаленою хронічною захворюваністю [1]. Неінвазивна вентиляція легень (NIV) може бути альтернативою інтубації та механічної вентиляції при лікуванні немовлят, що потребують проведення пролонгованої респіраторної підтримки [2].

\section{META РОБОТИ}

Удосконалити способи та визначити критерії вибору респіраторної підтримки у новонароджених з гіпоксично-ішемічною енцефалопатією (ГІЄ).

\section{МАТЕРІАЛИ ТА МЕТОДИ}

Обстежено 48 немовлят, що знаходились на лікуванні у відділенні реанімації новонароджених обласної дитячої клінічної лікарні м. Запоріжжя. Середній термін гестації склав $38,6 \pm 1,34$ тижні, середній вік після народження $1,3 \pm 0,59$ днів.

Через 72 години від народження стан хворих оцінювали згідно стадій ГІЄ за шкалою Sarnat. Підгрупу 1 склали пацієнти 32 стадією (n=38), підгрупу 2 - пацієнти 33 стадією $(\mathrm{n}=10)$. Хворі обох підгруп знаходились на традиційній механічній вентиляції легень. Після проведення комплексного додаткового обстеження приймалось рішення про подальшу дихальну підтримку.

\section{РЕЗУЛЬТАТИ}

При дослідженні системної гемодинаміки виявлено, що хворі підгрупи 2 мали достовірно нижчий серцевий індекс $-3,80 \pm 0,63$ л/хв $/ \mathrm{M}^{2}$, в порівнянні з показниками у підгрупи $1-5,63 \pm 1,11 л / х в / \mathrm{m}^{2}$, при $\mathrm{p}<0,01$.

При дослідження стану кровотоку в передній мозковій артерії найбільші зміни торкались діастолічної перфузії головного мозку. Її швидкість виявилась вірогідно нижче у хворих 2 підгрупи $-9,73 \pm 0,36 \mathrm{~cm} /$ сек. проти $13,28 \pm 0,44$ см/сек. у хворих 1 підгрупи, при $\mathrm{p}<0,05$. За даними амплітудно-інтегрованої енцефалографії $(\mathrm{aEEГ)} \mathrm{у} 36$ дітей $(94,7 \%) 1$ підгрупи, виявлений постійний патерн $з$ нормальним вольтажем.

Узагальнюючи отримані результати, приймали рішення щодо можливості застосування неінвазивної дихальної підтримки. Новонароджених підгрупи 1 екстубували, та переводили на неінвазивну назальну вентиляцію легень. Хворим 2 підгрупи продовжували проводити традиційну ШВЛ.

\section{ВИСНОВКИ}

Основними критеріями для застосування ранньої NIV у доношених новонароджених 3 ГIЄ $€$ стабільна центральна та церебральна гемодинаміка, та обов`язковий аналіз даних аЕЕГ, що вказують на позитивний неврологічний прогноз.

\section{СПИСОК ЛІТЕРАТУРИ}

1. Roberts $C$. Davis P. G. Oven L. S. Neonatal non-invasive respiratory support: synchronised NIPPV non-synchronised NIPPV or Bi-level CPAP: what is the evidence in 2013 ? Neonatology. 2013. V. 104. P. 203 209 .

2. Katherine L Fedor. Noninvasive Respiratory Support in Infants and Children// Respiratory Care 2017;62(6):699-717.

\section{Клигуненко Е.Н., Кравец О.В. \\ АНАЛИЗ СОСТОЯНИЯ ВОДНЫХ СЕКТОРОВ И ЦЕНТРАЛЬНОЙ ГЕМОДИНАМИКИ У БОЛЬНЫХ В УРГЕНТНОЙ АБДОМИНАЛЬНОЙ ХИРУРГИИ ПРИ РЕСТРИКТИВНОЙ ИНФУЗИОННОЙ ТАКТИКЕ}

ГУ ДМА МОзУ, Кафедра анестезиологии, интенсивной терапии и медицины неотложных состояний ФПО, Днепропетровск

\section{АКТУАЛЬНОСТЬ}

Приоритетом периоперативной помощи при острой абдоминальной патологии является периоперативная инфузионная терапия. Целью последней является восстановление и поддержание жидкостного и электролитного баланса в условиях больших внешних и внутренних потерь, при необходимости проведения неотложного хирургического вмешательства. Этим достигается нормоволемия, сохранение физиологических объемов водных секторов и обеспечивается адекватная тканевая перфузия и оксигенация тканей. Анализ доказательных исследований по ведению больных с хирургической патологией выявил приоритетное влияние периоперационной инфузионной терапии на развитие послеоперационных осложнений и летальности (Cao F., 2012; Awad S., 2013; Fieldheiser A., 2016).

\section{ЦЕЛЬ}

Оценить состояние водных секторов и центральной гемодинамики у больных с ургентной хирургической патологией при рестриктивной тактике периоперационной инфузионной терапии (ИТ).

\footnotetext{
- Клевакіна О.Ю., Анікін І.О., 2018

- Клигуненко Е.Н., Кравеи О.В., 2018
}

\section{МАТЕРИАЛЫ И МЕТОДЫ}

Обследовано 30 больных, оперированных в ургентном порядке в объеме лапаратомия. Среди обследованных было 16 мужчин и 14 женщин, среднего возраста $60 \pm$ \pm 11 лет.

Критериями включения в исследования были: пациенты ургентной абдоминальной хирургии; возраст от 45 до 75 лет; степень анестезиологического риска по ASA III-IV E; прогнозируемый процент послеоперационной летальности выше 1 \% по шкале POSSUM; информированное согласие пациента на участие в исследовании.

Критериями исключения из исследования являлись: плановые оперативные вмешательства в абдоминальной хирургии; возраст до 45 или более 75 лет; степень анестезиологического риска по ASA I-II E; прогнозируемый процент послеоперационной летальности ниже $1 \%$ по шкале POSSUM; желудочно-кишечные кровотечения; объем интраоперационной кровопотери выше I уровня по Брюсову; отказ пациента от участия в исследовании. Инфузионная предоперационная подготовка и последующая инфузионная терапия проводилась 
исходя из степени дегидратации больного по Шелестюку П.Г. согласно адаптированной нормограммы (Клигуненко Е.Н., Кравец О.В., 2017).

Средняя продолжительность оперативного вмешательства составляла $60,6 \pm 20,3$ минуты. Тотальная внутривенная анестезия с ИВЛ у всех больных проводилась согласно стандартной схеме на фоне тотальной миопелгии ардуаном больным проводилась ИВЛ: в режиме SIMV (нормовентиляция), $\mathrm{FiO}_{2}=0,5$.

Нами изучены клинические показатели системной гемодинамики: артериальное давление (АД), среднее артериальное давление (САД), частота сердечных сокращений (ЧСС) и рутинные клинические лабораторные анализы (общий анализ крови и мочи, коагулограмма, биохимический анализ крови). Методом интегральной реографии аппаратом «Диамант» определяли показатели центральной и периферической гемодинамики: сердечный индекс (СИ), общее периферическое сосудистое сопротивление (ОПСС), ударный индекс (УИ). Исследованы такие показатели водных секторов организма как объем внеклеточной жидкости (ОВнекЖ), объем внутриклеточной жидкости (ОВнутЖ), общий объем жидкости (ООЖ), объем плазмы (ОП) методом неинвазивной биоэлектричной интегральной оценки структуры тела мониторным комплексом «Диамант».

Точки контроля: до операции, после предоперационной подготовки, через 24 часа, на 2, 3, 5, 7, 10 и 14 сутки послеоперационного периода.

\title{
РЕЗУЛЬТАТЫ ИССЛЕДОВАНИЯ И ИХ
}

\section{ОБСУЖДЕНИЕ}

Анализ показал исходное снижение у больных внутриклеточного и плазменного объемов на $4 \%$ и $5 \%$ ниже нормы соответственно. Это совпадало со II степенью дегидратации по Шелестюку и сопровождалось увеличением ЭО на $12 \%$ выше нормы и внеклеточного сектора на $6 \%$. Общий объем жидкости при этом сохранялся в пределах нормы.

Относительная гипердинамия (СИ превышал нормальные значения на $11 \%$, УИ - на $14 \%$ ) поддерживалась спазмом сосудов (ОПСС выше нормы на 6\%) и тахикардией (ЧСС

выше нормы на 12\%). Это сохраняло значения АД на уровне нормы.

После проведение предоперационной инфузионной подготовки сбалансированными солевыми кристаллоидными растворами в объеме $1733 \pm 340$ мл мы отмечали дальнейшее увеличение ОВнеклЖ до $9 \%$ выше нормы, восстановление ОП и ОВнутЖ до нормальных на фоне превышения ООЖ на 2,5\% от нормы. Восстановление объемов водных секторов сопровождалось стабилизацией показателей центральной гемодинамики до нормодинамии при сохранении умеренной тахикардии (ЧСС $96 \pm 6$ уд в 1мин).

В 1 сутки наблюдения общий объем инфузии у больных составлял 4360 мл \pm 450 мл. Объемы водных секторов достоверно не отличались от тех же на момент окончания предоперационной инфузионной подготовки. Мы отмечали формирование нормодинамического типа кровообращения (СИ составлял 98\% нормы) на фоне показателей ОПСС $102 \%$ от нормы и сохранении значений ЧСС и АД в пределах физиологической нормы.

C 3 суток послеоперационного периода и до конца наблюдения описанные показатели статистически значимо не изменялись.

\section{ВЫВОды}

1. У больных среднего хирургического риска острая хирургическая патология формирует нарушения жидкостного обмена и центральной гемодинамики вызывая развитие:

- гиповолемии (за счет плазменного дефицита), внутриклеточной дегидратации и увеличения объема интерстициального пространства;

- относительной гипердинамии путем увеличения периферического сосудистого сопротивления и частоты сердечных сокращений.

2. Рестриктивная тактика инфузионной терапии у больных среднего хирургического риска сопровождается восстановлением физиологических объемов водных секторов и нормодинамического типа кровообращения уже с 3 суток послеоперационного периода.

\section{Коваль О.І. ${ }^{1}$, Коваль П.Б. ${ }^{2}$ СИСТЕМНІ НЕВІДКЛАДНІ СТАНИ В ДИТЯЧІЙ АМБУЛАТОРНІЙ СТОМАТОЛОГІЇ}

\author{
${ }^{1}$ Національний медичний університет імені О.О.Богомольця, \\ кафедра дитячої терапевтичної стоматології та проффілактики стоматологічних \\ захворювань \\ ${ }^{2}$ Стоматологічна клініка при НМУ імені О.О.Богомольця
}

\section{АКТУАЛЬНІСТЬ}

Невідкладні стани — це стани, при яких виникає декомпенсація життєво важливих функцій організму дитини (дихання, кровообігу, нервової системи) або небезпека їх виникнення. Першочергове завдання невідкладної терапії на дошпитальному етапі надати мінімально-достатній об'єм допомоги. По можливості, фактори ризику виникнення невідкладних станів, які можливо прогнозувати, повинні бути усунені або зведені до мінімуму до початку стоматологічного втручання 3 метою профілактики.

Мета дослідження: проаналізувати причини та частоту виникнення невідкладних станів в дитячій амбулаторній стоматології та провести аналіз надання екстреної допомоги

\section{МАТЕРІАЛИ ТА МЕТОДИ ДОСЛІДЖЕННЯ}

Системні ускладнення в стоматологічній практиці виникають при наявності загальносоматичних захворювань пацієнта та посилюються під впливом оперативного втручання: порушення дихання при бронхіальній астмі, зупинка серця при вроджених вадах або захворюваннях

\footnotetext{
о Коваль О.І., Коваль П.Б., 2018
}

ССС, судоми при епілепсії, непритомність, асфіксія, анафілаксія - при токсичному ефекті місцевих анестетиків.

В стоматологічній клініці при НМУ імені О.О.Богомольця протягом 2-х років проведено санацію порожнини рота 1300 дітям віком від 3-х до 18-ти років, які мали як абсолютні, так і відносні показання до санації порожнини рота в умовах загального знеболення [3, 4]: 23,08\% дітей мали хронічні загальносоматичні захворювання в т.ч. захворювання ССС (в основному вроджені вади серця), 26,92\% дітей мали психоневрологічні вади розвитку, 3,85\% дітей мали в анамнезі епілепсію, $11,54 \%$ дітей - ДЦП, 42,31\% дітей мали відносні показання («криптогенні» фобії, істерію).

Невідкладні стани були відмічені у 0,7\% дітей.

Клінічні прояви, виявлені при невідкладних станах:

1. Порушення свідомості.

2. Порушення гемодинаміки.

3. Порушення дихання.

4. Судоми. 
Кожен вид невідкладних станів має свої особливості проведення реанімаційних заходів. Універсальною, основною допомогою при всіх тяжких невідкладних станах $\epsilon$ серцево-легенева реанімація (при зупинці серця), якою повинен володіти лікар будь-якої спеціальності, в тому числі і стоматолог.

На перше місце в СЛР ми ставимо - непрямий масаж грудної клітини, на друге - за можливістю проведення дефібриляції (у дітей початкова енергія розряду повинна складати 2 Дж/кг, якщо ця величина недостатня спробу повторюють 3 енергією розряда 4 Дж/кг).

Найбільш ефективним при реанімаційних заходах є в/в введення адреналіну. Адреналіна гідротартрат $0,18 \%$ в ампулах (розчин 1:1000) - містить в собі 0,01 мг (10 мкг) адреналіна в 0,01 мл.

\section{ВИСНОВКИ}

1. Невідкладні стани - це стани, при яких виникають декомпенсація життєво-важливих функцій організму дитини (або є небезпека їх виникнення).

2. Лікар-стоматолог зобов'язаний вміти надавати долікарську допомогу згідно кваліфікаційним вимогам до лікаря - стоматолога MO3 України.

3. В кожному стоматологічному кабінеті повинні знаходитися аптечки 3 препаратами для надання невідкладної допомоги.

4. В пріоритеті СЛР - непрямий масаж серця, потім штучне дихання.

5. Важливою умовою успіху реанімації $\epsilon$ наявність дефібрилятора (негайний доступ до нього та навики в користуванні).
6. Найбільш ефективним та універсальним препаратом при реанімаційних заходах є адреналін.

\section{СПИСОК ЛІТЕРАТУРИ}

I. Безвушко E.B., Микичак I.В. Взаємозв'язок карієсу зубів із соматичною патологісю в дітей, ялі прозсивають у районах, різиит са екологічною ситуачісю. Український стонатологічнй альнанах NQ4. 2012.

2. Опанасюк Ю.В. Протоколи надання стоматологічної допомоги. / Ю.В.Опанасюк // ТОВ Виавничий інформачійний чентр "Світ сучасної стоматології» - 2005. - 236 с

3. Прохно О.І., Коваль П.Б. Клініко-психологічне обгрунтування показань до санації порожнини рота дітей різного віку в умовах загального знеболення. // Неонатологія, хірургія та перинатальна медичина. T.4, №2(12), 2014

4. Прохно О.I. Показання до санації порожнини рота дітей різного віку в умовах загального знеболення (клініко-психологічне обтрунтування). Психічне здоровя. Вип. 3(4). 2014p.C. 30-35.

5. Прохно О.I. Особливості проведення саначї порожнини рота у дітей дошкільного віку в умовах загального знеболення. Частина 1: Лікування неускладненого карієсу тимчасових зубів у дітей дошкільного віку в умовах загального знеболення. М Вісник проблем
біології та медицини. Випуск 4, том 3 (115). Рік 2014. С. 328-334.

6. Прохно О.І. Особливості проведення санації порожнини рота у дітей дошкільного віку в умовах загального знеболення. Частина II: Лікування ускладненого карієсу тимчасових зубів у дітей дошкільного віку в умовах загального знеболення. // Вісник проблем біології та медицини. Випуск 1 (117). Рік 2015. С. 310-315.

7. Стош В.И., Рабинович С. А., Зорян Е.В. Руководство по анестезиологии и оказанию неотложной помощи в стоматологи.

8. Olga I. Prokhno, Petro B. Koval. Clinikal and psychological basis of indications for oral cavity sanation in children of different ages under general anesthesia/ Olga I. Prokhno, Petro B. Koval. // International conference Materials, Methods and Technologies. Bulgaria -2014 . - V.8.

9. Prokhno O.I. Treatment of caries and its complications in preschool children under general anesthesia. // International Conference on European Science and Technology. Munich. Germany. 2015. October 21-22. P.266-272.

\title{
Коваль П.Б. МОНИТОРИНГ ТКАНЕВОЙ ОКСИГЕНАЦИИ ВО ВРЕМЯ ЛАПАРОСКОПИЧЕСКИХ АБДОМИНАЛЬНЫХ ОПЕРАЦИЙ
}

\author{
КБ «Феофания»
}

\section{АКТУАЛЬНОСТЬ ПРОБЛЕМЫ}

Региональная оксигенация (РО) отражает баланс доставки и потребления кислорода тканями и демонстрирует эффективность кислородного транспорта во время анестезии. В настоящее время, для оценки насыщения кислородом тканей головного мозга во время анестезии и при различных состояниях в реаниматологии широко используется церебральная оксиметрия, которая является одним из частных случаев РО.

Большой практический интерес вызывает возможность использования мониторинга оксигенации периферических $\left(\mathrm{StO}_{2}\right)$ тканей и органов. Сведения о применении этого метода в абдоминальной лапароскопической хирургии на данный момент единичны.

\section{ЦЕЛЬ ИССЛЕДОВАНИЯ}

Оптимизировать ранюю диагностику изменений кислородного обеспечения головного мозга и почек у пациентов во время лапароскопических вмешательств под эндотрахеальным наркозом с применением ингаляционного анестетика севорана.

\section{МАТЕРИАЛ И МЕТОДЫ}

Исследовано 30 пациентов, которым были выполнены лапароскопические операции- холецистектомии по поводу ЖКБ и на органах малого таза по поводу патологии матки и придатков. Возраст больных от 28 до 75 лет (средний возраст $56,4 \pm 13,8$ лет). Все пациенты по исходному физическому статусу относились к I-II классу ASA.

Эндотрахеальный наркоз - индукция пропофолом в стандартних дозировках. Поддержание анестезии прово- дилось $\mathrm{N}_{2} \mathrm{O}+$ севоран (до 1.5 об\%) с добавлением фентанила. Миоплегия поддерживалась тракриумом.

Выделены 4 этапа анестезии: до индукци; ингаляция севорана; пневмоперитониум; после дезинтубации трахеи. Мониторинг осуществлялся в соответствии с Гарвардским стандартом (ЭКГ, САД, SpO, , ЕТСО, ). Показатели церебральной SctSO, и ренальной оксиметрии ( $\left.\mathrm{SrtO}_{2}\right)$ регистрировались с помощью монитора INVOS Somanetics (США).

\section{РЕЗУЛЬТАТЫ ИССЛЕДОВАНИЯ И ИХ ОБСУЖДЕНИЕ}

Результаты исследований представлены в табл. №1. Исходные показатели церебральной оксигенации и ренальной оксигенации находились в пределах нормы, однако отмечалось достоверное повышение церебральной оксигенации по сравнению с ренальной. Эта разница по преимуществу кислородного насыщения мозга в сравнении с почками сохранялась после индукции и в начале ингаляции севорана, соответственно на $8,9 \%$ и на $10,5 \%(\mathrm{p}<0,05)$. На остальных этапах операции и анестезии эта разница полностью нивелировалась, показатели церебральной и почечной оксигенации практически не отличались.

Во время индукции пропофолом, на этапе с начала ингаляции севорана, обращает на себя внимание отсутствие изменений $\mathrm{SctO}$ и $\mathrm{SrtO}$, однако, отмечается достоверное снижение напряжения углекислоты в альвеолярном газе на втором этапе контроля в пределах нормы.

Во время операции в условиях анестезии севораном показатели $\mathrm{SrtO}_{2}$ увеличивались. Изменения в мозговом 
MATERIALS OF THE CONGRESS OF ANAESTHESIOLOGISTS OF UKRAINE September 13-15, 2018

кровотоке по данным церебральной оксиметрии практически отсутствовали.

На этапе пробуждения, после прекращения поступления севорана, оксиметрические показатели оставались в пределах нормы, достоверно превосходя исходные данные ренальной оксигенации. При этом не обнаружено изменений значений САД, числа сердечных сокращений и величины насыщения кислородом артериальной крови $\left(\mathrm{SpO}_{2}\right)$.

\section{PAIN, ANAESTHEESIA \& INTENSIVE CARE INO 20198}

\section{ВЫВОДЫ}

- Во время анестезии у больных при лапаро-скопических опреациях на органах брюшной полости не происходит патологических измений региональной и церебральной оксигенации.

- Кислородный резерв мозга до операции выше чем аналогичные показатели оксигенации почек.

- Применение севорана для общей анестезии во время лапароскопических операций на органах брюшной полости

Таблица 1. Динамика $\mathrm{SO}_{2}$ и физиологических параметров организма на этапах лапароскопических операций $(n=32, M \pm m)$

\begin{tabular}{c|c|c|c|c|c|c}
\hline $\begin{array}{c}\text { Показатели. } \\
\text { Этапы }\end{array}$ & SctO $_{2} \%$ & SrtO $_{2} \%$ & AД ср. мм.рт.ст. & $\begin{array}{c}\text { еtCO } \\
\text { мм. Ал }\end{array}$ & чСт. & SpО $_{2} \%$ \\
\hline 1 & $76,3 \pm 2.35$ & ${ }^{* *} 69.5 \pm 1,61$ & $104,5 \pm 4,0$ & $34,7 \pm 0,8$ & $63,1 \pm 2,2$ & $97 \pm 2$ \\
\hline 2 & $78,0 \pm 1.86$ & ${ }^{* *} 69.8 \pm 2,54$ & $98,9 \pm 3,6$ & $32,2 \pm 0,9^{*}$ & $57,2 \pm 2,7$ & $99 \pm 3$ \\
\hline 3 & $77,6 \pm 1,79$ & $70,9 \pm 3,0$ & $105,2 \pm 5,6$ & $33,2 \pm 1,3$ & $58,8 \pm 2,8$ & $96 \pm 2$ \\
\hline 4 & $75,9 \pm 2.06$ & $78,6 \pm 3,2^{*}$ & $97,9 \pm 4,0$ & $33,4 \pm 1,3$ & $63 \pm 2,5$ & $98 \pm 2$ \\
\hline
\end{tabular}

Примечание: ** $p<0,05$ по сравнению с исходным , * $p<0,05$ между SctO ${ }_{2} \%$ и SrtO ${ }_{2} \%$.

Таким образом, комбинированная оксиметрия является удобным и информативным методом неинвазивного интраоперационного мониторинга кислородного статуса и кровенаполнения головного мозга и почек. При ингаляционной анестезии севораном отмечалось стабильность кислородного обеспечения головного мозга и достоверное увеличение оксигенации почек. позволяют добиться достаточной оксигенации мозга и почек у пациентов различного возраста и пола.

- Тканевая и церебральная оксиметрия позволяет оценить степень оксигенации и микроциркуляции во время анестезии.

Список литературы находится в редакции журнала «PAIN, ANAESTHESIAAND INTENSIVECARE/БЛЬ,ЗНЕБОЛЕННЯ ТА IHТЕНСИВНА ТЕРАПІЯ»

\section{УДК 616.12-008.331= УДК: 616.8 \\ Ковальова О.В. ${ }^{1}$, Маляренко Ю.О. ${ }^{2}$, Ковальова О.B. ${ }^{2}$, Кошля О.B. ${ }^{1}$ \\ УСУНЕННЯ ЦЕФАЛГІЇ ПРИ КОМПЛЕКСНОМУ ЛІКУВАННІ ГІПЕРТОНІЧНОГО КРИЗА ТЛІ ПАТОЛОГІЇ ШИЙНОГО ВІДДІЛУ ХРЕБТА}

\section{${ }^{1}$ ДЗ «ЗМАПО МОЗ України» Кафедра терапії, фрізіотерапії, курортології і профпптології 2ЗНТУ Кафедра спеціальної освіти та реабітології}

Кожен 4-й випадок смерті при неконтрольованій артеріальній гіпертензії (АГ) пов'язаний з гіпертонічним кризом [2]. Тільки кожний десятий хворий на АГ здатен досягнути цільового рівня артеріального тиску (АТ) [2]. Кожен 3-й з неконтрольованою АГ вмирає від мозкового інсульту, термінальної ниркової дисфункції або серцевої недостатності $[2,3]$.

\section{META}

Розробка програми усунення внутрішньомозкового тиску, цефалгії на тлі гіпертонічного кризу при патології шийного відділу хребта.

\section{ОБ'ЄКТ ДОСЛІДЖЕННЯ}

20 осіб, хворих на гіпертензію в поєднанні з патологією шийного відділу хребта, які отримували стандартну медикаментозну терапію, 21 пацієнт отримував лікування в комбінації з фізіотерапевтичним лікуванням. Групи хворих були підібрані за віком (середній вік $62 \pm 4,2$ ), вагою (індекс Кетле в 1-й групі -від 21,63 кг $\mathbf{M}^{2}$ до $33,13 \kappa \Gamma \backslash \mathbf{M}^{2}$, у 2-й - від $20,75 \kappa \Gamma \backslash \mathbf{M}^{2}$ до $\left.36 \kappa \Gamma \backslash \mathrm{M}^{2}\right)$, перебігу захворювання.

Патологію хребта в першій групі при рентгенологічному дослідженні діагностували в 6 випадках в шийно-грудному відділі і в 8 - в шийному відділі, а в другій - в 8 випадках в шийно-грудному відділі і в 8 - в шийному. У всіх пацієнтів відзначалася головний біль при кризі, зміні погоди, при стресі. Хворі перебували під спостереженням від 3 до 6 місяців. 3 огляду на фізіологію людей похилого віку, неможливо забезпечити адекватне зниження АT і аналгезію цефалгічних форм в звичних терапевтичних дозах. Виникають патологічні зв'язки, які не дозволяють утримувати тиск на необхідному рівні.
В обох групах підвищення артеріального тиску відбувалося на тлі патології шийно-грудного відділу хребта. В обох групах діагностовано порушення мозкового кровообігу, зафіксована внутрішньочерепна гіпертензія, порушення ліквородинаміки. Для лікування використовували апарат LEIT, який виробляє модульований електричний сигнал MEC. Робота по рефлексогенним зонам електричним струмом, що не ушкоджує та максимально копіює ендогенний (нейроподібний імпульс в діапазоні частот від 8 до 140 Гц) дозволяє отримувати потужний анальгезуючий, протизапальний ефекти, сприяє нормалізації лимфовідтоку поліпшенню ликвородинаміки, зниженню внутрішньочерепного тиску Дані феномени були досліджені за допомогою ЕЕГ, доплерографії $з$ дуплексним скануванням. Оцінка больового синдрому і його динаміка в процесі лікування гіпертонічних кризів оцінювалися за числовою шкалою болю (NPS - Numeric Pain Scale, ЧШБ) [1].

При застосуванні LEIT зникав головний біль, відчуття «розпирання» в голові, поліпшувався зір, зникали «мушки» перед очима. Відновлювалася чутливість до гіпотензивних препаратів. Нормалізувалася формула сну.

\section{вИСновки}

Застосування МЕС дозволило, при збереженні адекватних цифр AT, зменшити дозу гіпотензивних препаратів, стабілізувати ликвородинаміку, усунути вегетативну дисфункцію нервової системи, усунути больовий синдром, в порівнянні $з$ контрольною групою.

\section{СПИСОК ЛІТЕРАТУРИ}

Налапко Ю.И., Малыи И.Р. Шкала боли в экстремальной медицине Экстремальная медицина. Алгоритмы и стандарты оказания неотложной медицинской помощи взрослым и детям: Мат-лы Межобл. науч.-практ. конф. анестезиологов / Под ред. проф. А.И. Трещинского. - Луганск, 1999. - С. 43-54.
Vidt D G. 2001. Mozaffarian D. et al. National Heart, Lung, and Blood Institute, 2003; CDC, 2011 


\title{
Ковальова О.В. ${ }^{1}$, Строкань В.В. ${ }^{3}$, Таран Г.I. ${ }^{2}$, Ковальова O.B. ${ }^{2}$ ЗАСТОСУВАННЯ МОДУЛЬОВАНОГО ЕЛЕКТРИЧНОГО СТРУМУ ПРИ КОМПЛЕКСНОМУ ЛІКУВАННІ БОЛЬОВОГО СИНДРОМУ
}

\author{
'ДЗ «ЗМАПО МОЗ України» Кафедра терапії, фрізіотерапії, курортології і профрпатології \\ 2знТУ Кафедра спеціальної освіти та реабітології \\ зякимівська центральна района лікарня
}

Біль - один з найпоширеніших клінічних симптомів і синдромів, що супроводжує травму як в гострому так і а післяопераційному періоді. Існуючі в даний час протоколи післяопераційного знеболювання забезпечують адекватну аналгезію не більше ніж у $40 \%$ пацієнтів[3].

Мета роботи - обгрунтування доцільності застосування модульованого електричного сигналу (МЕC) 3 метою адекватної аналгезії в умовах травматологічного відділення.

Обстежено 30 пацієнтів (дорожньо-транспортні пригоди, виробничі травми), всі чоловіки. Ізольовані переломи мали $33,3 \%$ осіб, множинні і поєднані травми були у $66,6 \%$, поєднання $з$ ЧМТ (струс і забиття легкої середнього ступеня) - у $23,3 \%$. Середній вік $-48 \pm 2,3$ року. Групи хворих були ідентичними за віком, вагою, характером травм.

Стандартну медикаментозну терапію отримували 14 пацієнтів, а 16 в комбінації з модульованим електричним сигналом фізіотерапевтичного апарату LEIT. Апарат працює в діапазоні частот від 8 до 140 Гц.

Больовий синдром і його динаміка оцінювалися як в доопераційний період, так і в ранній післяопераційний. Використовувалася числова шкала болю (NFS - Numeric Pain Scale) [2]. Застосування MEC сприяло досягненню більш швидкого та якісного аналгетичного ефекту, що дозволило знизити дозу наркотичних анальгетиків, особливо в ранньому післяопераційному періоді, в порівнянні 3 контрольною групою у $56,25 \%$. Завдяки поліпшенню мікроциркуляції локально відзначався виражений ефект по усуненню набряків, прискорене розсмоктування гематом Комплексне лікування позитивно позначилося на репаративному процесі і відновленню обсягу руху в пошкоджених кінцівках. Скорочувався термін лікування.

При терапії LEIT у хворих з наслідками ЧМТ відзначався регрес загальномозкової та оболонкової симптоматики, часткове або повне відновлення больової і температурної чутливості.

Застосування МЕС є доречним в хірургії та травматології, при підготовці до оперативного втручання, а також в післяопераційному і відновлювальному періоді.

\section{СПИСОК ЛІТЕРАТУРИ}

Ковалева О.В., Фуштей И.М., Паламарчук А.И., Порада Л.В., Фучтей А.И., Koвалева $A$ B. Неноmop Ковалева А.В. Некоторые аспекты физиотерапевтического лечения болевого серіатрів Украіи (Киї, 11-13 әсовтия 2005 р.): Тези доповідей $/ /$ Проблемы

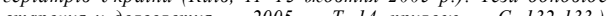

2. Налапко Ю.И., Мальи И.Р. Шкала боли в экстремальной медицине // Экстремальная медицина. Алгоритмы и стандарты оказания неотложной медицинской помощи взрослым и детям: Мат-лы Межобл. науч.-практ. конф. анестезиологов / Под ред. проф. А.И. Трещинского. - Луганск, 1999. - С. 43-54. Овечкин А.М., Романова Т.Л. Послеоперационное обезболивание: оптимизация Овечкин А.М., Романова Т.Л. Послеоперационное обезболивание: оптимизаиия
подходов с точки зрения доказательной медицинь // Русс. мед. журн. - 2006. №12. - C. 865-872

4. Пономаренко Г. Н. Электротерапия и электролечение. - СПб.: Мир и семья-95, 1995. - $250 \mathrm{c}$.

Современные аспекты обезболивания в современной практике: Практическое руководство / Под ред А.И. Трещинского, Л.В. Усенко, И.А. Зупанца. К.: МОРИОН, 2000. $-64 c$

\section{Ковтун А.І., Бойко Ю.Г., Ковтун О.А., Кифяк П.В., Мартим'янов А.Ю. ВПРОВАДЖЕННЯ СУЧАСНИХ МЕТОДІВ ЕФЕРЕНТНОЇ ТЕРАПІЇ У ЛІКУВАННЯ ХВОРИХ У КРИТИЧНОМУ СТАНІ}

Буковинський державний медичний університет, м. Чернівці

\section{АКТУАЛЬНІСТЬ}

Спектр використання еферентних методів детоксикації (ЕМД) у інтенсивній терапії надзвичайно широкий. У основі ЕМД лежать чотири основні процеси: дифузія гемодіаліз, гемодіафільтрація; фільтрація (конвекція) гемофільтрація, каскадна плазмофільтрація, ізольована ультрафільтрація; сорбція - плазми, крові, лімфи, ліквору, імуносорбція; центрифугування (гравітація) плазмоферез (ПФ), каскадний плазмаферез, цито плазмоферез, тромбоцитоферез, лейкоцитоферез, аутотрансфузія крові, кріофільтрація, фотоферез плазми крові.

Мета роботи - визначити покази до різних аферентних методів зі сторони доказовості, розглянути методи, що раніше не використовувались у практиці лікарів інтенсивної терапії, дослідити вплив сучасних методів детоксикації на стан хворого.

\section{МАТЕРІАЛ ТА МЕТОДИ}

Аналіз опрацьованої літератури свідчить, що абсолютними показами до ЕМД є: синдроми Гієна-Барре, Гудпасчера, Вегенера, тромбоцитопенічна пурпура, міастенія гравіс, кріоглобулінемія, сімейна гіперхоле- стеринемія. Доведено також ефективність їх у лікуванні отруєнь, розсіяного склерозу, системного червоного вовчаку, конфлікту за групою АВО при вагітності, сепсису, панкреатиту, псоріазу, синдромів Лайєла та Стівенса-Джонсона.

У дослідження увійшли 30 хворих у віці від 22 до 66 років 3 гнійно-септичними ускладненнями у післяопераційному періоді (18), гепатитом С (12). У лікуванні сепсису застосовували плазмаферез із замінним переливанням плазми, що давало можливість видалити токсичні медіатори септичного синдрому та утримати рівень білка крові на безпечному рівні, тому він ефективніший від блокування окремих компонентів процесу. Встановлено, що ранній початок аферентної терапії є кращим в порівнянні з відстроченим початком. Плазмаферез 3 подвійною фільтрацією (каскадний) використовували у хворих на гепатит С для видалення ліпопротеїдів низької щільності, токсинів, продуктів розпаду, імунних комплексів та самого вірусу гепатиту С.

\section{РЕЗУЛЬТАТИ}

У наших дослідженнях, під час яких вивчали ефективність обміну плазми для лікування сепсису, вижива- 
ність хворих склала 70\% при використанні плазмаферезу, в порівнянні з прогнозованим коефіцієнтом виживання 40\%. У пацієнтів 3 важким сепсисом, які отримали 1-5 процедур, рівень прозапальних цитокінів знижувався протягом 2-3 процедур. Однак, зниження рівня цитокінів не впливало на рівень смертності. Рівень альбуміну в плазмі крові після сеансу плазмаферезу з подвійною фільтрацією на $42 \%$ був вищим ніж у пацієнтів після звичайного сеансу плазмаферезу.

\section{ВИСновок}

Хворі у важкому стані, які не реагують на стандартне лікування, потребують використання сучасних методів очистки крові, які не лише забезпечують видалення патологічного агенту, але й мають переваги над традиційними методами детоксикації.

\section{СПИСОК ЛІТЕРАТУРИ}

Eisei Noiri, Norio Hanafusa. The Concise Manual of Apheresis Therapy Tokyo: Springer, 2014, P-418.

2. Tina S. Ipe., Huy P. Pham., Lance A. Williams. Critical updates in the $7^{\text {th }}$ edition of the American Society for Apheresis Guidelines Journal of Clinical Apheresis. February 2018. - V. 33, Issue 1.

3. Воинов В.А. Эфферентная терапия. Мембранный плазмаферез. Издание пятое, перераб. и доп. - М., «Новости», - 2009. - $304 \mathrm{c}$.

UDC: 616.345-008.87-053.3:575.857:616.34-002

\title{
Kovtun A.I., Konovchuk V.M., Kovtun O.A., Martimianov A.E. INFLUENCE OF HYPERBARIC OXYGENATION ON KIDNEY FUNCTION IN PATIENTS WITH PURULENT-SEPTIC COMPLICATIONS
}

\author{
Bukovinian State Medical University, Chernivtsi, Ukraine
}

\section{BACKGROUND}

The problem of patient treatment with abdominal purulentseptic complications in postoperative period especially with the common purulent peritonitis is one of the most urgent problems of modern surgery. This is due to the prevalence of peritonitis $(5-7 \%$ from the total number of abdominal interventions) and the high mortality, which varies. Method of hyperbaric oxygenation (HBO) has gained strong positions in the treatment of abdominal purulent-septic complications in postoperative period, first of all, due to the quick utilization of nitrogen and electrolytes, that is connected with liquidation of hypoxia, improvement of cellular respiration processes, activation of respiratory enzymes, increase of the proportion of aerobic glycolysis, increase of oxidative phosphorylation in the liver. Use of HBO improves removal of nitrogen by the kidneys, contributes to the quick liquidation of intoxication and restoration of motor activity of the intestine, reduction of urea, final nitrogen and creatinine in blood plasma.

\section{OBJECTIVE}

To examine functional state of kidneys in patients with abdominal purulent-septic complications in the postoperative period under conditions of hyperbaric oxygenation.

\section{MATERIALS AND METHODS}

Clinical examinations and treatment of 118 patients with abdominal purulent-septic complications in the postoperative period, namely widespread peritonitis, were carried out. The control group consisted of 28 practically healthy people.

\section{RESULTS}

In patients with abdominal purulent-septic complications, a significant decrease in diuresis (by $40 \%$ ) was observed in the first 24 hours after surgery, compared to the control group $(\mathrm{p}<0.05)$, although they were receiving traditional intensive therapy. The drop of $47 \%$ in glomerular filtration rate (GFR) caused the decrease in diuresis since changes in the water reabsorption processes in the kidney canals did not compensate for GFR disturbances. Application of hyperbaric oxygenation as a part of the complex therapy resulted in GFR increase and, accordingly, in the growth of daily diuresis.

\section{CONCLUSIONS}

1. For the renewal of the functional state of the kidneys in patients with abdominal purulent-septic complications, the use of sessions of hyperbaroxemia in standard therapeutic regimens is effective.

2. Early application of hyperbaroxemia in patients with purulent-septic complications contributes to the renewal of ion and volumeregulatory functions of the kidneys by increasing the glomerular filtration rate, sodium clearance and secretion of potassium by renal nephrons.

\section{REFERENCES}

I. Poliansky I.Yu., Moroz P.V., Moskaliuk V.I., Andriiets V.V., Grynchuk A.F. Likuvannia pervtonitu - shliakh vid dorazovoi do personalizovanoi medycyny [Treatment of peritonitis - the way from evidence-based to personalized medicine]. Kharkiv surgical school. 2017; l (82): 59-64 [in

2. Hrynchuk F.V., Polianskyi I.Iu., Maksymiuk V.V. Kompleksna profilaktyka rannikh zapalno-destructyvnykh uscladnen hostroho perytonitu [Comprehensive prevention of early postoperative inflammatory and destructive complications of acute peritonitis]. Klinichna anatomiia ta operatyvna khirurhiia. 2012; 11 (3): 92-94 [in Ukrainian].

3. Lam G., Fontaine R., Ross F.L., Chiu E.S. Hyperbaric Oxygen Therapy: Exploring the Clinical Evidence. J. Advances in Skin end Wound Care. Exploring the Clinical

\section{Коломаченко B.I.}

\section{ІНЦИДЕНТНІСТЬ НЕБАЖАНИХ ЯВИЩ ПРИ ЕНДОПРОТЕЗУВАННІ КУЛЬШОВОГО СУГЛОБА В УМОВАХ РІЗНИХ ВИДІВ ЗНЕБОЛЮВАННЯ}

\author{
Харківська медична академія післядипломної освіти, Харківська обласна клінічна
} травматологічна лікарня; Харків, Україна

Для ендопротезування кульшового суглоба (ЕКС) може застосовуватись і загальна (3А), і регіонарна анестезія (PA), остання може включати чи то блокади периферичних нервів (БПН), чи то нейраксіальну анестезію (НА): спінальну (СА), епідуральну (ЕА), комбіновану спінально-епідуральну (КСЕ) та каудальну. Більшість методів РА можуть також застосовуватись для післяопераційної (ПО) аналгезії. Мета нашого дослідження - аналіз ПО ускладнень і небажаних ефектів шістьох опцій анестезії та ПО аналгезії, застосованих для ЕКС.

\section{МАТЕРІАЛИ ТА МЕТОДИ}

ЗА або РА використана для ЕКС у 398 пацієнтів, віком від 24 до 95 років. У групі I $(\mathrm{n}=78)$ застосована CA; у групі II (n=69) - CA + пролонгована паравертебральна блокада; у групі III $(\mathrm{n}=68)-\mathrm{CA}+$ пролонгована епідуральна блокада; у групі IV (n=69) - псоаскомпартмент блок + блокада nervus ischiadicus; у групі V

\footnotetext{
- Kovtun A.I., Konovchuk V.M., Kovtun O.A., Martimianov A.E., 2018

- Коломаченко B.I., 2018
} 
$(\mathrm{n}=63)$ - каудальна + пролонгована паравертебральна блокада; у групі VI (n=51) - 3А.

\section{РЕЗУЛЬТАТИ}

M'язова слабкість не зустрічалася у групах IV та VI, вона траплялася найчастіше у групі III (9\%), де призвела до падіння у 2 пацієнтів $(3 \%)$. Безсоння було найбільш частим у групах I (18\%) та VI (20\%), вірогідно через більший ПО біль.

Опіоїди потребувалися найчастіше після 3А, у групі VI, де $24 \%$ пацієнтів скаржилися на загальну слабкість або запаморочення і мали найбільш часту ПО нудоту та блювання $(22 \%)$ і неспроможність їсти впродовж перших 24 годин $(30 \%)$

Ортостатична гіпотензія була найбільш частою (18\%) у групі ІІІ (з пролонгованою ПО ЕА).

Затримка сечі була дуже частою після НА: 47\%, 35\%, $47 \%$ та $33 \%$ у групах I, II, III та V відповідно.
Загальне число ускладнень і небажаних ефектів було меншим після БПН (групи II, IV, V) і більшим після CA, KСЕ та 3А (групи I, III, VI).

Задоволення пацієнтів у групах II, IV та V було значно вищим, ніж у групах I та VI, воно було значно вищим у групі II, ніж у групах I, III, IV та VI.

\section{вИсновки}

Серед досліджених опцій для ЕКС РА безпечніша за ЗА, а БПН безпечніші за НА.

\section{СПИСОК ЛІТЕРАТУРИ}

1. Greimel F. No clinical difference comparing general, regional, and combination anesthesia in hip athroplasty. a mullicenter cohort-stady regarding perioperative pain management

2. Kendrisic M. Surgical stress response following hip arthroplasty regarding choice of anesthesia and postoperative analgesia. M.Kendrisic, M.Surbatovic, D.Djordjevic et al. // Vojnosanit Pregl.-2017.-№74(12).-p.-1162-1169.

3. Liang C. Efficacy and safety of 3 different anesthesia techniques used in total hip arthroplasty. C.Liang, J.Wei, X.Cai et al. // Med Sci Monit.-2017.-No2(23).-p. 3752-3759.

\title{
Коробко Е.Ю., Георгіяни М.А., Кривобок В.І. ВИБІР МЕТОДУ КОМБІНОВАНОЇ АНЕСТЕЗІЇУ ХВОРИХ ТРАВМАТОЛОГІЧНОГО ПРОФІЛЮ
}

\section{АКТУАЛЬНІСТЬ}

Регіонарна анестезія забезпечує адекватну блокаду ноцицептивної імпульсації, однак лише частково впливає на механізми перцепції болю, що є однією 3 причин неадекватності аналгезії та хронізації больового синдрому. Впровадження комбінованих методів знеболення та індивідуалізація вибору анестезії для цих хворих $є$ актуальним завданням [1,2].

\section{META}

Обгрунтувати вибір методу анестезії при операціях на нижніх кінцівках на підставі вивчення клінічних показників адекватності аналгезії та психологічного стану пацієнтів.

\section{МАТЕРІАЛИ ТА МЕТОДИ}

Обстежено 21 хворого, прооперованого 3 приводу травм нижніх кінцівок в КЗО3 «Харківській обласній клінічній травматологічній лікарні», яких розподілено на 2 групи: I $(\mathrm{n}=10 ; 51,3 \pm 8,0$ років $)$ - прооперовані в умовах провідникової анестезії (ПА), II (n=11; 47,3 $\pm 7,0$ років) - в умовах ПА 3 подальшою седацією $1 \%$ пропофолом 2 мг/кг/год.

Оцінювали показники гемодинаміки (ГД), інтенсивність болю (ІБ) за ВАШ, рівень ситуаційної (СТ) та особистісної тривожності (OT) за Спілбергом - Ханіним до та на першу добу після операції (п/о). Для статистичної обробки результатів застосовували критерій Стьюдента та критерій Манна-Уітні.

\section{РЕЗУЛЬТАТИ}

Визначався нормодинамічний режим ГД з середнім артеріальним тиском (САТ) в межах 90-110 мм рт. ст. Лише на інтраопераційному етапі у хворих II групи САТ був достовірно нижчим $92,8 \pm 4,5$ vs $109,8 \pm 6,7$ мм рт. ст. $(\mathrm{p}<0,05)$, що обумовлено гіпотензивною дією пропофолу. ІБ за ВАШ до операції $8,3 \pm 0,2$ vs $8,1 \pm 0,3$ бали, також визначені значні рівні $\mathrm{CT}(\mathrm{Me}=48$ vs $\mathrm{Me}=46)$ і $\mathrm{OT}(\mathrm{Me}=53$ vs $\mathrm{Me}=49$ ), що вказує на ІБ після травми та очікування оперативного втручання. Через добу п/о ІБ за ВАШ знижувалась, але була в межах середньої - 6,5 $\pm 0,2$ vs $4,7 \pm 0,4(\mathrm{p}<0,05)$. На 1 -шу добу п/о знижено рівень тривожності в обох групах, що обумовлено зниженням ІБ при анестезії і заспокоєнням хворих, у II групі більш виразне за ОТ $(\mathrm{Me}=35)$, ніж у I $(\mathrm{Me}=44)(\mathrm{p}<0,05)$.

Встановлено виразний коефіцієнт кореляції Спірмена між показником ВАШ через добу п/о - ОТ до операції (r=0,7); ВАШ через добу п/о - OT п/o $(\mathrm{r}=0,8)$ у пацієнтів I групи.

У II групі суттєві взаємозв'язки відсутні.

\section{ВИСНОВКИ}

Хворим травматологічного профілю доцільно перед операцією оцінювати показники тривожності за Спілбергом - Ханіним. При встановленні у пацієнта високої тривожності оптимальним методом знеболення є комбінована анестезія.

\section{СПИСОК ЛІТЕРАТУРИ}

Богуславська Н.Н. Вибір метода анестезіологічного забезпечення травматологічних операчій у пачієнтів молодого віку. / Н.Н. Богуславська, М.А. Георгіяни// Scientific Journal «ScienceRise». - 2015. - №7/4(12). - C. 28-35.

2. Ильясова Д.И. Опросник боли Мак - Гилла и шкала ВАШ, как метод определения уровня болевого синдрома у пациентов после абдоминальных операций. / Д.И. Ильясова, А.Ю. Марченко, В.В. Казариев// Вестник молодых ученых и спечиалистов Челябинской области. - 2017. - Т.3, №2 (17). - С. 36-39.

\section{Креньов К.Ю. \\ АБДОМІНАЛЬНИЙ ПЕРФУЗІЙНИЙ ТИСК, ЯК ПРЕДИКТОР ЛЕТАЛЬНОСТІ У ПАЦІЄНТІВ ІЗ ГОСТРОЮ ХІРУРГІЧНОЮ ПАТОЛОГІЕЮ ЧЕРЕВНОЇ ПОРОЖНИНИ}

\author{
Вінницький національний медичний університет ім.М.І.Пирогова \\ Хмельницька обласна клінічна лікарня
}

Синдром інтраабдомінальної гіпертензії та абдомінальний компартмент синдром можуть ускладнювати перебіг багатьох хірургічних захворювань черевної порожнини та призводити до розвитку та прогресування поліорганної недостатності. Визначення абдомінального перфузійного тиску (АПТ) та його динаміки дозволяє передбачити розвиток поліорганної недостатності та вчасно відкоригувати лікувальну тактику.

\section{АКТУАЛЬНІСТЬ}

Розвиток поліорганної недостатності $\epsilon$ провідною причиною смерті пацієнтів із гострою хірургічною

\footnotetext{
○ Коробко Е.Ю., Георгіяни М.А., Кривобок B.I., 2018

- Креньов К.Ю. , 2018
} 
MATERIALS OF THE CONGRESS OF ANAESTHESIOLOGISTS OF UKRAINE September 13-15, 2018

патологією. Велику роль в цьому відіграє абдомінальний компартмент синдром, цифри летальності при якому сягають дуже значних цифр - 42-68 \% і без лікування наближаються до $100 \%[1,2]$. Важливо вимірювати перфузійний тиск черевної порожнини, який визначає важкість та прогноз при синдромі інтраабдомінальної гіпертензії [3]. Він являє собою різницю між середнім артеріальним тиском та інтраабдомінальним тиском (IAT)

\section{META РОБОТИ}

Визначити динаміку АПТ у хворих з абдомінальним компартмент - синдромом.

\section{МАТЕРІАЛИ ТА МЕТОДИ}

На клінічній базі Хмельницької обласної клінічної лікарні проведено обстеження 30 пацієнтів із гострою хірургічною патологією черевної порожнини та ознаками інтраабдомінальної гіпертензії. 330 пацієнтів 20 вижило та 10 померло. Середній вік тих, що вижили $-55,1 \pm 14,4$ p. померлих $-60,7 \pm 16,8$ роки. Розподіл чоловіків та жінок у групах 14 та 6 у групі тих, що вижили та 4 та 6 в групі тих, що померли відповідно. Термін спостереження складав 72 години, на другу добу помер один пацієнт. Розподіл по нозологіях був наступним: політравма -8 (вижило 6 , померло 2), гострий деструктивний панкреатит, панкреонекроз - 8 (вижило 3 , померло 5), гострий деструктивний холецистит - 1 (помер 1), кишкова непрохідність - 2 (вижило 1, помер 1), перитоніт - 4 (вижило 3, помер 1), злоякісне новоутворення товстої кишки із перфорацією 2 (вижило 2), піддіафрагмальний абсцес - 1 (вижив 1) механічна жовтяниця - 3 (вижило 3 ), перфоративна виразка ДПК - 1 (вижив 1), мезентеріальний тромбоз - 1 (вижив 1). Всім пацієнтам проведено вимірювання внутрішньочеревного тиску з інтервалом 6 годин протягом трьох діб та розрахунок АПТ в зазначені терміни спостереження. Додатково були проаналізовані об'єм інфузії за 24 години в мл, кількість трансфузій препаратів крові, діурез, потреба в інотропній підтримці, тривалість ШВЛ в обох групах пацієнтів.
PAIN, ANAESTHAESIA \& INTENSIVE CARE WB 2018

\section{РЕЗУЛЬТАТИ}

Якщо в кінці першої доби відмінності в числових значеннях при вімірюванні обох показників були невірогідні $(24,3 \pm 16,6$ у тих, що вижили проти $24,4 \pm 13,0$ в померлих для IAT та $59,4 \pm 32,8$ у тих, що вижили проти $45,6 \pm 31,9$ в померлих для АПТ), то з кінця другої та в третю доби спостереження відмінності сягали достовірних значень із вираженою тенденцією до зростання IAT $(12,3 \pm 7,3$ проти $23,4 \pm 12,4$ в другу та $11,3 \pm 5,0$ проти $20,1 \pm 8,7$ в третю добу) та зниження АПТ $(77,7 \pm 14,8$ проти $56,0 \pm 16,9$ в другу та $85,6 \pm 11,9$ проти $57,0 \pm 21,7$ на третю добу) в групі пацієнтів, що померли. Летальний наслідок встановлено в пацієнтів із прогресивним зниженням АПТ незважаючи на використання інтенсивної ізотропної підтримки, оптимізацію інфузійно - трансфузійної терапії, ШВЛ. Також не було виявлено достовірної різниці в використанні препаратів крові в першу добу, об'ємі інфузій та об'ємі діурезу, однак достовірною була різниця в потребі інотропної підтримки та дозі інотропних агентів.

\section{ВИСНОВКИ ТА ПЕРСПЕКТИВИ ПОДАЛЬШИХ РОЗРОБОК}

1. АПТ корелює із летальними наслідками у пацієнтів із абдомінальним компартмент-синдромом та його розрахунок необхідно зробити рутинною практикою інтенсивної терапії.

2. Отримано вірогідні відмінності в показниках IAT та АТП тиску в пацієнтів, що вижили та померлих із чіткою тенденцією до зростання IАТ та зниження показників АПТ у пацієнтів із летальними наслідками.

\section{СПИСОК ЛІТЕРАТУРИ}

1. Алиев С. Б. (2013). Синдром интраабдоминальной гипертензии. /Хирургия. Журнал им. Н. И. Пирогова// 2013: 5: $63-67$.

2. Криворучко І.А., Лєсний В.В., Гончарова Н.М., Тесленко С.М., Сивожелізрв А.В. та співавт. (2018). Сучасні методи діагностики і лікування абдомінального компартмент - синдрому./Хірургія України// 2018: 1: 29-32.

Мазур А. П., Лисун Ю. Б., Шевченко В. М. (. Внутрибрюшное давление и внутрибрюшная гипертензия./ Клінічна хірургія // 2007: 2/3: 133 - 134.

\section{Kpiumaфpop A.A. \\ ЗАХИСТ І ВІДНОВЛЕННЯ КОГНІТИВНИХ ФУНКЦІЙ ПРИ КРИТИЧНИХ СТАНАХ}

\section{АКТУАЛЬНІСТЬ}

Критичні стани супроводжуються стресовим напруженням гомеостазу зі змінами функціювання всіх систем організму, що негативно впливає на ЦНС. Важливою задачею інтенсивної терапії є максимальне збереження когнітивних функцій, як одного з факторів, що забезпечують якість життя хворого в посткритичному періоді [1].

\section{META}

Визначити базові принципи профілактики і лікування когнітивних розладів, обумовлених критичними станами, та перевірити їх ефективність.

\section{МАТЕРІАЛИ ТА МЕТОДИ}

Обстежено 54 хворих, оперованих в плановому порядку: контрольна, I (тіоцетам ${ }^{\circledR}$ ) і II (реамберин ${ }^{\circledR}$ ) групи; 110 постраждалих 3 цивільною політравмою: контрольна, I (тіоцетам ${ }^{\circledR}$ ), II (реамберин ${ }^{\circledR}$ ) і III (холіну альфосцерат) групи; 84 поранених 3 бойовою травмою: контрольна, I (тіоцетам ${ }^{\circledR}$ ), II (реамберин ${ }^{\circledR}$ ) і III (холіну альфосцерат) групи. Проводилося клініко-лабораторне обстеження, визначення когнітивних функцій за шкалами CFQ [2] i MMSE, вираженість реакції на стрес за шкалою IES-R [3]. Досліджувався вихідний стан когнітивних функцій, на 2-гу добу після операції або травми, при переводі з відділення інтенсивної терапії, при виписці та через 3 місяці. Результати оцінювалися 3 використанням параметричних і непараметричних методів статистики.

\section{РЕЗУЛЬТАТИ}

Хворі за віком і вихідним соматичним станом у групах 3 однотипним видом критичного стану статистично не відрізнялися. На 2-гу добу після отримання операційної, цивільної або бойової травми когнітивні функції знижувалися в середньому на 13,4-13,9\% відносно вихідного рівня, визначеного ретроградно за шкалою CFQ. Це зниження зберігалося протягом всього госпітального періоду і частково зменшувалося через 3 місяці. В групах, які отримували тіоцетам ${ }^{\circledR}$, реамберин ${ }^{\circledR}$ і холіну альфосцерат, на 2-у добу зниження когнітивних функцій не перевищувало 8,3-9,7\% і при виписці 3 лікарні вони майже відновлювалися до вихідного рівня. Стрес, пов'язаний з участю в бойових діях, надавав додатковий негативний вплив на когнітивні функції, але й у цих хворих досліджувані препарати мали значний позитивний ефект. Через 3 місяці визначено найбільший позитивний вплив у тіоцетаму, що ймовірно пов'язано 3 ноотропною його дією.

\section{вИСновки}

Критичні стани, пов'язані 3 хірургічною або травматичною агресією викликають зниження когнітивних функцій, яке відповідає визначенню “когнітивна дисфункція”. Препарати, дія яких спрямована на захист мембран нервових клітин, покращення синаптичної передачі в ЦНС і клітинний метаболізм нейронів, здатні упередити когнітивну дисфункцію і прискорити відновлення нормального функціонування ЦНС в посткритичному періоді. 


\section{СПИСОК ЛІТЕРАТУРИ}

Фариатов Р.С. Качество жизни реанимачионных больных ка один из важнейщих показателей эффективности интенсивной терапии Р.С.Фаршатов, Р.Н.Кильдебекова // Журнал «Медици на». - 2016. - No2. - C.23-31

Волков А.О. Как оченить когнитивные функции перед кесаревым А.О Волков, Е.Н. Кдигуненко, И.А. Ветошка //
Современные проблемы науки и образования. - 2014. - №3; URL: https://science-education.ru/ru/article/view?id $=13474$

3. Мельницкая Т.Б. Шкала оченки влияния травматического события (IES-R) применительно к радиачионному фактору / Т.Б.Мельницкая, А.В.Хавыло, Т.В.Белых // Психологические исследования: электронный научный журнал. - 2011. - №5(19). URL: http://psystudy.ru/ index.php/num/2011n5-19/546-melnitskaya-et-al-19.html.

\title{
Крутько О.М., Середенко В.Г. ПОСТМАСТЕКТОМІЧНИЙ БОЛЬОВИЙ СИНДРОМ - МОЖЛИВОСТІ ПРОФІЛАКТИКИ НА СУЧАСНОМУ ЕТАПІ
}

УДК 618.19-006-009.7-0.36

\author{
«Iнститут медичної радіології ім. С.П.Григор'єва НАМН України» м.Харків
}

Постмастектоміческій больовий синдром (ПМЕБС) - це нейропатичний больовий синдром, що розвивається після оперативних втручань на молочній залозі. Як і багато інших форм невропатичного болю цей больовий синдром буває резистентним до багатьох засобів і методів лікування болю і призводить до відчутного зниження якості життя. Пошук засобів і методів його профілактики $€$ досить актуальним.

\section{МЕТА ДОСЛІДЖЕННЯ}

Оцінити вплив введення місцевих анестетиків в рану і застосування габапентину на інтенсивність і якісні характеристики гострого післяопераційного болю, i частоту розвитку постмастектоміческого больового синдрому.

\section{МАТЕРІАЛИ ТА МЕТОДИ}

У дослідженні брало участь 60 пацієнток, яким виконувалася радикальна мастектомія 3 пахвовою діссекціею лімфатичних вузлів під ТВВА. У групі $1(\mathrm{n}=30)$ призначали Габантин (Фарма-старт) за добу до втручання в дозі 1200 мг протягом 8 днів. Катетер до рани встановлювали після закінчення оперативного втручання. Друга група $(\mathrm{n}=30)$ отримувала системну мультимодальну аналгезию Дексалгіном, парацетамолом і Омнопоном в стандартному режимі і дозуваннях. Оцінювали інтенсивність болю по ВАШ в спокої і при русі через 4 , 12, і 24 години після операції в 1 день і 4 рази на добу протягом 10 днів. Якісні характеристики болю і ступінь вираженості нейропатичного компонента вивчали за допомогою опитувальників Pain Detect (PD), McGill, якість життя - по короткому опитувальником болю. В обох групах підраховували добове споживання аналгетиків в післяопераційному періоді. Повторний огляд та інтерв'ю проводили через 1 i 3 місяці. Ступінь вираженості тривоги і депресії верифікували за опитувальником Гамільтона, оцінка рухів в руці на стороні оперативного втручання здійснювалася за шкалою кінезіофобіi Тампа. Результати

В 1-групі було отримано значне зниження інтенсивності болю в спокої (ВАШ $1,5 \pm 0,4)$ і при русі $(2,1 \pm 0,8)$ протягом усього післяопераційного періоду в порівнянні 3 2-групою (ВАШ 3,5 $\pm 1,2$; ВАШ 5,8 $\pm 1,8$ ), $\mathrm{p}=0,002$. У 1-групі в ранньому післяопераційному періоді не було зареєстровано характеристик нейропатичного болю (PD $2,1 \pm 0,8)$, в порівнянні з 2- групою (PD 13,1 $\pm 3,7)$. Ступінь вираженості тривоги і депресії за шкалою Гамільтона склала в досліджуваній групі $7 \pm 1,6$ і $18 \pm$ 6,5 - у контрольній. Через місяць скарги на больові відчуття пред'являли тільки $12 \%$ пацієнток 1-групи та $64 \%$ в 2-групі, причому $35 \%$ були змушені приймати аналгетики практично щодня. Оцінка рухів на стороні операції за шкалою кінезіофобіі Тампа у жінок досліджуваної групи склала $19 \pm 3,4$ бала, у пацієнток контрольної групи $-45 \pm 11,2(\mathrm{p}=0,002)$. При огляді пацієнток досліджуваної групи через 3 місяці статистично достовірна тенденція скорочення формування ПМЕБС, в порівнянні з групою контрольної зберігалася.

\section{ВИСНОВКИ}

Використання Габантину (Фарма-старт) і мікроструйного введення Лонгокаіну в періопераційному періоді сприяє профілактиці ПМЕБС.

\section{СПИСОК ЛІТЕРАТУРИ}

Post-Mastectomy Pain Syndrome. The Magnitude of the Problem. Brazilian Journal of Anesthesiology. Volume 59, Issue 3, May-June 2009, Pages 358-365 Tania Cursino de Menezes Couceiro, Telma Cursino de Menezes, Marcelo Moraes Valknзa

2. Older Adult Emergency Department Pain Management Strategies. Clinics in Geriatric Medicine, Volume 34, Issue 3, August 2018, Pages 491-504.Lauren J. Gleason, Emily D. Escue, Teresita M. Hogan.

\section{Крутько О.М., Середенко В.Г. \\ УДК 616-006-08.7-0.39 \\ НУТРИТИВНА ПІДТРИМКА ЯК СКЛАДОВА КОМПЛЕКСНОЇ ТЕРАПІЇ ХВОРИХ ОНКОЛОГІЧНОГО ПРОФІЛЮ}

\author{
«/нститут медичної радіології ім. С.П.Григор'єва НАМН України» м. Харків
}

Сучасні методи хірургічного лікування хворих в онкології 3 року в рік набувають все більш агресивний характер. Серед хворих 3 онкологічною патологією досить широко поширена недостатність харчування. За даними ESPEN, нутритивну підтримку потребує близько $60-80 \%$ хворих, які перебувають на лікування у відділеннях анестезіологіi. На даний момент в Україні немає затверджених стандартів нутритивної підтримки у важкій категорії онкологічних хворих.

\section{МЕТА ДОСЛІДЖЕННЯ}

Вивчити стан білкового обміну і оцінити ефективність застосування парентерального і ентерального харчування в комплексі лікування хворих онкологічного профілю.

\section{МАТЕРІАЛИ І МЕТОДИ}

Проаналізовано застосування парентерального (ПХ) i ентерального харчування (EX) у 112 хворих, які перебувають у відділенні анестезіології «Інституту медичної радіології ім С.П.Григор'єва НАМН України» після виконання планових операцій з приводу колоректального раку, доброякісних пухлин товстого і тонкого кишечника, реконструктивно-відновлювальних операцій на товстій кишці. За характером штучного харчування хворі були розділені на 4 групи: в 1-й (28 хворих) проводили загальноприйняту інфузійно-трансфузійної терапії; у другій групі (26 хворих) харчування здійснювали через назоінтестінальний зонд, введений нижче анастомозу, в третій групі хворих (26 осіб) застосовували 
повне парентеральне харчування; в четвертій (32 хворих) використовували комбіноване ПХ в поєднанні 3 зондовим введенням поживних сумішей.

\section{РЕЗУЛЬТАТИ}

Початковий стан білкового обміну, імунного статусу характеризувався гіпо- та діспротенеміею, зменшенням альбуміно-глобулінового коефіцієнта (АГК) на 27-29,5\% ( $<<0,03)$. У хворих 1-ї групи вже в 1 добу після операції відзначалося зниження рівня загального білка на $11,8 \%$ $(\mathrm{p}=0,05)$ від вихідного рівня, альбуміну на $15,76 \%$ $(\mathrm{p}<0,05)$, зниження АГК на $26-29 \%(\mathrm{p}<0,05)$.У хворих, прооперованих з приводу колоректального раку, ці зміни були більш виражені. Негативний азотистий баланс відзначався до 10-х діб після операції. Частота ускладнень в 1-й групі склала $28,9 \%$.У 2-й групі хворих зниження загального білка, альбуміну тривало до 3 діб, після цього відзначався різкий підйом цих показників, відзначалася позитивна динаміка. Зменшення концентрації білка склало $19 \%(\mathrm{p}<0,05) .3$ 4-х, 5-х діб відзначався позитивний азотистий баланс. У цей момент хворим вводились поживні суміші через назоінтестінальний зонд до 2,0-2,5 літрів. Частота післяопераційних ускладнень в цій групі склала $13 \%(\mathrm{p}<0,05)$. У хворих 3-ї групи, починаючи з 5-ої доби, була виражена тенденція до нормалізації показників білкового обміну, імунного статусу.

\section{ВИСНОВок}

Проведене дослідження показує, що оптимальним варіантом харчування хворих після оперативних втручань 3 приводу колоректального раку, доброякісних пухлин товстого і тонкого кишечника є ентеральне зондове харчування в поєднанні із збалансованим парентеральним харчуванням.

\section{СПИСОК ЛІТЕРАТУРИ}

Nutritional support of the oncology patient.Critical Reviews in Oncology/ 2. Optimal Nutrition and Hydration Through the Surgical Treatment Trajectory. Seminars in Oncology Nursing, Volume 33, Issue 1, February 2017, Pages 6173. Carol DeNysschen, Mary E. Platek, Drew Hemler, Nell Aronoff, Michelle L. Zafron

\title{
Крутько О.М., Середенко В.Г. ВИКОРИСТАННЯ ЕПІДУРАЛЬНОÏ АНЕСТЕЗІЇ ІНТЕРВЕНЦІЙНОÏ ХІРУРГІЇ
}

\author{
«lнститут медичної радіології ім. С.П.Григор'єва НАМН України» м. Харків
}

В останні роки зріс інтерес до використання регіонарних методів анестезії. Це обумовлено сучасними уявленнями про патофізіологію гострого болю, з точки зору якої, адекватна анестезія передбачає необхідність забезпечення захисту спинного мозку від ноцицептивних впливів. Це створює адекватну анальгезію, оптимізує протягом операції та післяопераційного періоду. Серед пацієнтів досить осіб похилого та старечого віку з супутньою серцево-судинною патологією. Найбільший ризик представляють пацієнти 3 високою артеріальною гіпертензією, ішемічною хворобою серця, аритміями, які отримують антигіпертензивну та антиаритмічну терапію.

\section{META РОБОТИ}

Оцінка безпеки та ефективності бупівокаїну (Лонгокаін), як препарату вибору при епідуральній анестезії під час операції у відділенні інтервенційної хірургії (абляції метастазів, хіміоемболізації судин)

\section{МАТЕРІАЛИ І МЕТОДИ}

Лонгокаін застосовували у 26 пацієнтів обох статей, анестезіологічний ризик по American Society of Anestesiologists (ASA) 1-3 у віці від 43 до 74 років, середньою масою тіла $58 \pm 2,34$ кг, зростом $170 \pm 2,05$ см. Премедикація стандартна. В операційній пункція епідурального простору проводилася в положенні хворого сидячи або лежачи на боці, на рівні T10 - L3, пацієнтам застосовувався Лонгокаін $0,75 \%$ - в дозі від 20 до 30 мг, в кожному випадку використовувався одноразовий набір для епідуральної анестезії з голкою типу Туохі $18 \mathrm{G}$. Ефективність блокади оцінювалася за допомогою візуальних аналогів болю і безперервним інтраопераційним моніторингом основних параметрів гемодинаміки (Mediana). Під час операції хворий знаходився в контакті з оперуючим хірургом і анестезіологом.

\section{РЕЗУЛЬТАТИ}

Тривалість аналгезії в середньому становила $147 \pm 15$ хв. Перебіг анестезії стабільний, пацієнти перебували в свідомості, скарг не пред'являли, емоційно були спокійні. Токсичний прояв місцевого анестетика не спостерігався. В післяопераційному періоді 3 метою знеболення досить було ненаркотичних анальгетиків.

\section{ВИСНОВКИ}

Застосування лонгокаіна в епідуральної анестезії вважається одним з альтернативних і безпечних методів регіонарної анестезії. Тривала аналгезія, відсутність токсичної дії дозволяє поліпшити якість життя пацієнтів в ранньому післяопераційному періоді, проводиться рання активізація хворих.

\section{СПИСОК ЛІТЕРАТУРИ}

1. KC Cummings, F Xu, LC Cummings, GS Cooper: A comparison of epidural analgesia and traditional pain management effects on survival and cancer recurrence after colectomy. Anesthesiology, 116 (2012), pp. 797-806.

2. Effect of thoracic epidural anaesthesia on serum vascular endothelial growth factor $C$ and cytokines in patients undergoing anaesthesia and surgery for colon cancer: Y.J.Xu,W.K.Chen, Y.Zhu. British Journal of Anaesthesia Volume 113, Supplement 1, July 2014, Pages i49-i5.

\section{Кущ К.О., КлИгУНенко О.М. \\ ДИНАМІКА РІВНЯ НЕЙРОНСПЕЦИФІЧНОЇ ЕНОЛАЗИ У ХВОРИХ В ГОСТРОМУ ПЕРІОД ІШЕМІЧНОГО ІНСУЛЬТУ}

\author{
ДЗ «Дніпропетровська медична академія МОЗ України» \\ Кафедра анестезіології, інтенсивної терапії та МНС ФПО
}

\section{МЕТА ДОСЛІДЖЕННЯ}

Дослідити вплив нейрометаболічної терапії на рівень нейронспецифічної енолази у хворих 3 гострим ішемічним інсультом (ГІІ).

Матеріали та методи: до проспективного рандомізованого дослідження увійшов аналіз лікування 80 пацієнтів 3 гострим порушенням мозкового кровообігу за

Крутько О.М., Середенко В.Г., 2018

Куш К.О., Клигуненко О.М. , 2018 ішемічним типом (14-20 балів за NIHSS), які госпіталізовані у перші 24 години від початку захворювання. Серед обстежених було $46(57,5 \%)$ чоловіків та $34(42,5 \%)$ жінок. Середній вік пацієнтів коливався від 51 до 84 років $(68 \pm 5,4)$.

Концентрацію нейронспецифічної енолази (НCE) у сироватці крові визначали методом імуноферментного 
аналізу у перші 3-8 годин від початку захворювання, на 3 та 6 добу. В залежності від виду нейрометаболічної терапії хворих було розподілено на 2 групи (за методом конвертів). Групи не відрізнялися за віковим чи гендерним складом.

До 1 групи (контрольної) увійшло 45 хворих, у лікуванн яких нейрометаболічною складовою був цитіколін. Його вводили внутрішньовенно по 1000 мг 2 рази на добу протягом 14 діб.

2 групу (основну) складало 35 хворих, яким до цитіколіну додавали введення Медотиліну. Препарат вводили внутрішньовенно по 1000 мг на добу протягом 14 днів.

\section{РЕЗУЛЬТАТИ ТА ÏХ ОБГОВОРЕННЯ}

При надходженні хворих до стаціонару всі хворі мали порушення свідомості за шкалою ком Глазго (ШКГ). У $20(42 \%)$ з них порушення свідомості дорівнювало 7-8 балам, що відповідало комі І ступеню, а у 28 (58\%) пацієнтів становило 9-12 балів (сопор). При нейровізуалізації головного мозку у всіх пацієнтів виключено геморагічний інсульт. Тяжкість хворих не мала міжгрупових відмінностей та становила за NIHSS $18 \pm 1,7$ балів, за шкалою FOUR $11 \pm 0,8$ балів, за Coma Recovery Scale $11 \pm 0,8$ балів.
Встановлено, що рівень НСЕ при надходженні становив

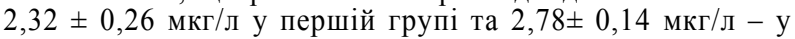
другій, що на $69,7 \%$ та $63,8 \%$ відповідно було нижчим від норми добровольців даної вікової групи. У хворих 1 групи рівень НСЕ підвищувався до $10,7 \pm 1,6$ мкг/л на 3 добу із подальшим зниженням до $8,88 \pm 0,64$ мкг/л на 6 добу. Це перевищувало референтні значення норми $\mathrm{HCE}$ для даної вікової групи, що ми пов'язали із ступенем тяжкості ГІІ. На тлі проведення нейрометаболічної терапії (2 група) зниження НСЕ було значно більшим: на 3 добу спостереження іï рівень становив $6,0 \pm 0,57$ мкг/л, на 6 добу $-5,78 \pm$ $\pm 0,36$ мкг/л, що достовірно $(p>0,05)$ відрізнялося від показників контрольної групи. Це могло свідчити про зменшення ураження головного мозку під впливом Медотиліну та підтверджувалося прискореними виходом iз коми (тривалість стану пригніченої свідомості була на $34 \%$ меншою) та регресом неврологічної симптоматики (за шкалою NIHSS).

\section{ВИСНОВКИ}

Комбінація Медотиліну із цитіколіном сприяє зниженню $(\mathrm{p}<0,05)$ HCЕ на 6 добу на $35 \%$ та прискорює відновлення неврологічного дефіциту. Це дозволяе нам рекомендувати комбіновану нейрометаболічну терапію в гострому періоді ішемічного інсульту.

\section{ОСОБЛИВОСТІ ПЕРЕБІГУ СПІНАЛЬНОЇ АНЕСТЕЗІЇ ПРИ ОПЕРАТИВНИХ ВТРУЧАННЯХ В ПОЛОЖЕННІ НА ЖИВОТІ}

\section{АКТУАЛЬНІСТЬ}

3 удосконаленням хірургічної техніки лікування кил поперекового відділу хребта все більше пацієнтів обирають оперативне втручання через його високу ефективність та швидкий результат. При оперативних втручаннях нижче L3 рутинно використовується спінальна анестезія [1], проте немає однозначних рекомендацій щодо техніки їі виконання для оперативних втручань у положенні на животі, а саме вибору місцевого анестетика, його дози та баричності [2].

\section{META РОБОТИ}

Провести порівняльний аналіз використання ізобаричного та гіпербаричного бупівакаїну при оперативних втручаннях на поперековому відділі хребта у положенні на животі.

\section{МАТЕРІАЛ ТА МЕТОДИ ДОСЛІДЖЕННЯ}

До дослідження включено 144 пацієнти за ASA I-II, віком 18-65 років для проведення планового оперативного втручання 3 приводу дегенеративнодистрофічних захворювань хребта на рівні L3 та нижче. Пацієнти були розподілені на 3 рівні групи. Паціснтам групи 1 спінальна анестезія виконувалась гіпербаричним розчином бупівакаїну 0,5\% - 3,5 мл у проміжку L3-L4 або L2-L3 у положенні сидячі голкою G25. Після анестезії пацієнт вкладався на спину у горизонтальне положення подушкою під головою на 5 хвилин. Через 5 хвилин пацієнт перевертався на живіт за допомогою медичного персоналу. У групі 2 пацієнтам виконувалась така сама анестезія, проте пацієнт знаходився у горизонтальному положенні 10 хвилин, після чого повертався персоналом на живіт. У групі 3 спінальна анестезія виконувалась ізобаричним розчином бупівакаїну $0,5 \%$ - 3,5 мл. Одразу після введення анестетика пацієнт вкладався на живіт самостійно. Усім пацієнтам проводилась преінфузія 200 мл розчину Рінгера. Рівень сенсорного блоку (pinprick test) оцінювався у всіх пацієнтів через 15 хвилин від моменту введення місцевого анестетика та через 3 години, моторний блок оцінювали за шкалою Bromage.

\section{РЕЗУЛЬТАТИ ДОСЛІДЖЕННЯ ТА ЇХ ОБГОВОРЕННЯ}

Усі пацієнти мали достатній рівень аналгезії для проведення оперативного втручання тривалістю до 3 годин. Рівень сенсорного блоку був достовірно вище у обох групах застосування гіпербаричного розчину порівняно з ізобаричним, проте у всіх випадках був достатнім для проведення оперативного втручання на хребцях L3 та нижче (хірургічний розріз при цьому починається відповідно на 1-1,5 сегменти вище). Моторний блок був однаковим Bromage 3 у всіх пацієнтів. Через 3 години рівень сенсорного блоку був достовірно вищим у групі 1, порівняно із двома іншими групами, а рівень моторного блоку був вищим у групі 2. Найсуттєвіші зміни гемодинаміки виявлені у пацієнтів групи 2, пацієнти групи ізобаричного бупівакаїну мали найбільш стабільні показники гемодинаміки. Оперативне втручання починалось швидше у групі 3.

\section{ВИСНОВКИ}

1. При виконанні оперативних втручань на хребті нижче L3 у положенні на животі тривалістю до 3 годин доцільніше використовувати ізобаричний бупівакаїн, оскільки він має менший вплив на гемодинаміку та $€$ можливість починати оперативне втручання швидше.

2. Використання гіпербаричного розчину бупівакаїну може бути доцільним при виконанні більш тривалих оперативних втручань. Час експозиції у положенні на спині до повороту на живіт слід рекомендувати 5 хвилин. Більший час експозиції не впливає на тривалість блоку, але викликає суттєвіші зміни гемодинаміки.

\section{СПИСОК ЛІТЕРАТУРИ}

1. Perioperative outcome and cost-effectiveness of spinal versus general anesthesia for lumbar spine surgery / Kahveci K1, Doger C2, Ornek D// Neurol Neurochir Pol. - 2014. - Vol.48(3). - P.167-73. doi: 10.1016) j.pjnns.2014.05.005.

2. Imbelloni L.E. Spinal Hemianesthesia: Unilateral and Posterior / L.E. Imbelloni // Anesth Essays Res. - 2014. - Vol. 8(3). - P. 270-276. DOI: Imbelloni Anesth Essays Res. 


\title{
Лисенко В.Й., Голяніщев М.О. РОЗРОБКА ТА ВПРОВАДЖЕННЯ СИМУЛЯЦІЙНОГО НАВЧАННЯ МЕТОДИКАМ PEГIOHAPHOÏ AHECTE3IÏ
}

\begin{abstract}
Харківська медична академія післядипломної освіти, Харків, Україна

\section{АКТУАЛЬНІСТЬ}

Розробка методів адекватної анестезії призвела до неспинного зросту використання різних методик регіонарної анестезії (РА), водночас, позитивні властивості цих методик можуть нівелюватись побічними ефектами. Велика частка побічних ефектів РА зумовлена механічним впливом пункції, тому наявність у лікаря-анестезіолога мануального навику досягнення цільового анатомічного утворення 3 «першої пункції» $є$ пріоритетним завданням етапу навчання лікарів методикам РА. Опанування мануальними навичками лікаряанестезіолога потребує, поміж інших, розробку та впровадження симуляційного компоненту під час навчання лікарів-анестезіологів методикам РА. Цьому сприяють

віднести: прозорі стінки, дві рухомі полички 3 макетом нерву, кришка та отвори всередині кришки, що виконані під різним кутом відносно поверхні кришки. Під час тренінгу працюють стажер та інструктор за розробленими правилами.

Шляхом аналізу даних ситуативно запропонованих письмових опитувальників двох груп курсантів кафедри, було проведено пілотне дослідження ефективності симуляційного навчання 3 використанням пристроюсимулятора. Перша група (N=23) - лікарі, що навчалися без залучення до роботи з симулятором, та друга група $(\mathrm{N}=23)$ - лікарі, що навчалися із залученням до роботи 3 симулятором.
\end{abstract} загально відомі переваги симуляційного тренінгу: клінічний досвід без ризиків для пацієнта, об'єктивна оцінка опанованого рівня майстерності, необмежена кількість повторів навички, тренінг поза часом роботи клініки, частину функцій викладача бере на себе симулятор, знижується рівень стресу при виконанні самостійних маніпуляцій.

У доступній літературі найбільша увага приділена симуляторам, які дозволяють засвоювати нейроаксиальні методи та лише невелика кількість симуляторів-тренажерів розроблена для відпрацювання провідникових методик анестезіï. Водночас, велика коштовність медичних high tech манекенів-тренажерів накладає значні обмеження по їх впровадженню у навчальний процес. 3 іншого боку існують дослідження, які демонструють позитивне навчальноприкладне значення симуляторів-тренажерів більш простих конструкцій, тому менш коштовних.

Таким чином, актуальним виглядає завдання по розробці пристрою-симулятора 3 помірною собівартістю для відпрацювання мануального навику досягнення цільового анатомічного утворення 3 «першої пункції», який $є$ базовим для всього спектру РА, та може бути впроваджений на всіх етапах безперервного розвитку фахівця у сфері охорони здоров'я.

\section{МЕТА ДОСЛІДЖЕННЯ}

Покращення засвоєння мануального навику виконання регіонарних методик анестезій шляхом розробки та впровадження пристрою-симулятора для відпрацювання регіонарних анестезій на етапі післядипломного навчання.

\section{МЕТОДИ ТА МАТЕРІАЛИ ДОСЛІДЖЕННЯ}

Спираючись на дані літератури, доступну профільну інформацію, особистий досвід, було розроблено та відтворено у реальну модель пристрій-симулятор для РА. Пристрій-симулятор виконано у вигляді коробки на опорі розмірами $220 \cdot 360 \cdot 50$ мм. До основних елементів якого слід

\section{РЕЗУЛЬТАТИ ТА ОБГОВОРЕННЯ}

Серед курсантів 3 симуляційним навчанням визначено: більший рівень мотивації до опанування технікою РА, більша частота «питань до інструктора по суті», більша частота вірних відповідей на тестові запитання за темою. Серед лікарів-курсантів другої групи визначено групи стажерів: «сміливі» (здебільшого робили прокол «нерву»), «обережні» (не доводили голку) та «технарі» (намагались будь-яким чином отримати об'єктивні орієнтири), - що дозволило сформувати нові моменти для теоретичного супроводу 3 боку викладача.

Отримані результати вказують на позитивний практичний вплив впровадження симуляційного компоненту навчання зі спеціальності шляхом залучення розробленого та застосованого пристрою-симулятора регіонарних анестезій.

\section{вИСновки}

Початкові результати впровадження пристрою-симулятора для відпрацювання регіонарних анестезій дозволили покращити якість опанування мануального навику виконання регіонарних методик анестезій.

\section{СПИСОК ЛІТЕРАТУРИ}

1. Neil Vaughan, Venketesh N. Dubey, Michael Y.K. Wee, Richard Isaacs. A review of epidural simulators: Where are we today? // Medical Engineering \& Physics. - 2013. Vol. 35(9). - P. 1235-1250; doi.org/10.1016/j.medengphy.2013.03.003.

2. Lahham S. Procedural simulation: medical student preference and value of three task trainers for ultrasound guided regional anesthesia / S. Lahham, T. Smith, J. Baker, A. Purdy and coathors. // World J. Emerg. Med. - 2017. - Vol. 8(Suppl. 4). - P.287-291.; doi: 10.5847 /wjem.j.1920-8642.2017.04.007

3. Stone L. Low cost simulation training in anaesthesia / L. Stone, A. Hellewell // Update in Anaesthesia. - 2014. - Vol. (Suppl. 29). - P.44-46.

4. Raj D. Simple epidural simulator: a blinded study assessing the 'feel' of loss of resistance in four fruits / D. Raj, R.M. Williamson, D. Young, D.A. Russell // European Journal of in four fruits $/$ D. Raj, R.M. Williamson, D. Young,
Anaesthesiology. - 2013. - Vol. 30. - P.405-408.

5. Loss of resistance: A randomised controlled trial assessing four low-fidelity epidural puncture simulators. Pedersen T.H., Meuli J., Plazikowski E. J., Buttenberg M., KleineBrueggeney M. and coauthor's // European Journal of Anaesthesiology. - 2017. - Vol. 34 (Suppl. 9) - P.602-608. doi: 10.1097/EJA.0000000000000640.

\section{Ліпич О.П., ЛісещьКИЙ В.А.}

\section{РІВЕНЬ ГЛІКЕМІЇ ПЛАЗМИ КРОВІ ЯК ПОКАЗНИК ЗАГАЛЬНИХ ПРОЯВІВ СТРЕС-РЕАКЦІЇ НА ОПЕРАЦІЙНУ ТРАВМУ ТА АДЕКВАТНІСТЬ АНЕСТЕЗІОЛОГІЧНОГО ЗАБЕЗПЕЧЕННЯ ПРИ АБДОМІНАЛЬНИХ ОПЕРАЦІЯХ}

\section{Українська військово-медична академія}

Будь-яка операція - це стрес для організму. Стрес, зумовлений захворюванням, операційною травмою, післяопераційним больовим синдромом (ПБС), впливом ряду медикаментів тощо. Все це призводить до розвитку небажаних побічних реакцій зі сторони всіх систем організму і впливає на результат та тривалість стаціонарного лікування пацієнта. Тому для анестезіолога важливим є контроль стрес-відповіді організму на хірургічну агресію та захист від усіх небажаних ефектів ПБС (Бишовець С.М., 2013, Сорокіна Є.Ю.,2015).

\footnotetext{
Лисенко В.Й., Голяніщев М.О., 2018

- Ліпич О.П., Лісецький В.А. , 2018
} 
Одним із виявів метаболічної відповідності на травму є гіперглікемія (Обухова О.А., 2011). Це пов'язано з порушенням балансу між інсуліном та катаболічними гормонами (кортизолом, катехоламінами, глюкагоном). Що вагомішим $\epsilon$ періоперативний стрес, то значнішою $\epsilon$ гіперглікемія (Коваленко В.Л., 2010). Гіперглікемія збільшується як при кардіальних, так і при некардіальних операціях (Feringa H.Н., 2008).

Мета роботи - провести ретроспективний аналіз рівня глікемії у хворих, прооперованих з приводу гострої тонкокишкової непрохідності (ГТКН), та порівняти їх рівень при різному знеболенні пацієнтів 3 метою можливого використання для об'єктивної оцінки адекватності анестезіологічного забезпечення хірургічних втручань, терапії тонкокишкової непрохідності.

\section{МАТЕРІАЛИ І МЕТОДИ}

Виконано ретроспективний аналіз 40 пацієнтів, прооперованих в 2015-2017 рр. шляхом лапаротомії з приводу ГТКН, зумовленою спайковим процесом, на базі Національного військово-медичного клінічного центру «Головний військовий клінічний госпіталь». У 20 осіб (контрольна група) операція проходила під багатокомпонентною внутрішньовенною анестезією 3 інтубацією трахеї та ШВЛ, а п/о знеболення проводилось опіатами (промедол) та НПЗП (кейвер). У інших 20 (дослідна група) оперативне втручання здійснювалось аналогічно, але для знеболення вводили епідурально $1 \%$ p-ну лідокаїну(4-6 мл/год.) під час і після операції протягом 2 днів. За віком, статтю, індексом маси тіла, ризиком по ASA, тривалістю операції та супутньою патологією відмінностей між групами не було. У хворих при поступленні в стаціонар мали місце водно-електролітні порушення, зумовлені ГТКН, які були скориговані за допомогою інтенсивної інфузійної терапії (IT), діурез при цьому був збережений. Після IT електроліти плазми крові були: $\mathrm{K}^{+}$4,0-4,8 ммоль/л, С1-99-108 ммоль/л, $\mathrm{Na}^{+}$137-146 ммоль/л.

Рівень глікемії визначався до операції та у наступні 5 днів о 06:00 год. Варто відмітити, що у хворих не було використання гормонів (кортизолу та інсуліну), які могли вплинути на результат дослідження.

\section{РЕЗУЛЬТАТИ}

У хворих, яким п/о знеболення здійснювалось опіатами та НПЗП, рівень болю в перші години після операції був вищим, ніж у пацієнтів з епідуральною аналгезією (ЕА), i 13 з 20 хворих (65\%) потребувало додаткового знеболення промедолом відразу п/о та 7 (35\%) - у першу п/о добу. До операції рівень глікемії у контрольній групі становив $7,76 \pm 0,89$ ммоль/л, у дослідній $-7,32 \pm 0,91$ ммоль/л. Через 6 год. п/о відповідно: $6,96 \pm 0,65$ та $6,02 \pm 0,55$ ммоль/л. Через добу: $6,28 \pm 0,40$ і $5,32 \pm 0,24$ ммоль/л. На третю добу: $5,74 \pm 0,39,5,02 \pm 0,23$ ммоль/л. Четверта доба: $5,42 \pm 0,42$, $4,93 \pm 0,22$ ммоль/л. П'ята доба: $5,02 \pm 0,36,4,53 \pm 0,29$ ммоль/л. Тобто у всіх пацієнтів 3 ЕА рівень глікемії крові був нижчим. В залежності від знеболення статистична різниця рівня глікемії (рб>0,05) зберігається на першу і другу добу п/о лікування.

Аналіз показав, що при застосовуванні ЕА $з$ лідокаїном п/о відмічалося добре знеболення, відсутність нудоти і блювання, поява перистальтики на 2 добу п/о лікування у $12(60 \%)$ хворих та у $7(35 \%)-$ на 3 . На 2-3 добу хворі пили, починали їсти і це сприяло їх ранній активізації та дозволило зменшити період стаціонарного лікування. Цікаво, що хворі, у яких глікемія була на рівні 4-5 ммоль/л раніше активізовувались, починали їсти, ходити та виписувались на $8,6 \pm 0,7$ днів, в той час як у тих пацієнтів,

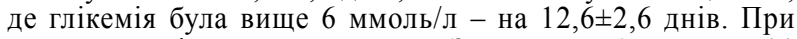
застосуванні промедолу та НПЗП для знеболення у 11 (55\%) хворих була нудота, перистальтика з'явилася на 3 добу у $9(45 \%)$, а стілець - у $7(45 \%)$ на 4 добу. У всі цих хворих був підвищений рівень глюкози, що вело до повільного одужання.

Таким чином, при стрес-реакції і запаленні збільшується рівень глікемії плазми крові. Зменшення стрес-реакції залежить від анестезіологічного забезпечення і знеболення. Використання місцевих анестетиків епідурально дозволило досягти не лише достатнього знеболення, швидкого відновлення перистальтики та ентерального харчування хворих на фоні стабільної гемодинаміки і доброго самопочуття, а й допомогло підтримувати рівень нормоглікемії в післяопераційному періоді. В той час, як у аналогічних хворих при застосуванні опіатів і НПЗП та недостатньому анестезіологічному забезпеченні відмічались прояви стрес-реакції і супроводжувались підвищенням рівня глюкози крові. Для об'єктивної оцінки пригнічення стрес-реакції і запалення, адекватності знеболення може використовуватись рівень глюкози крові, як простий, доступний і ефективний метод оцінки проявів стресу при відсутності захворювань підшлункової залози.

\title{
Мазур Г.М. МОДЕЛЮВАННЯ ПРОГНОЗУ ПРИ СЕПТИЧНОМУ ШОЦІ
}

\author{
Вінницький національний медичний університет ім.М.І.Пирогова.
}

\section{АКТУАЛЬНІСТЬ}

Доволі частим ускладненням у хірургічних хворих $\epsilon$ сепсис та септичний шок, смертність при яких сягає до $80 \%$. Останнім часом з'явилось досить багато шкал оцінки важкості стану хворих. Серед сучасних систем якісної оцінки важкості стану найбільшу популярність мають шкали, в основі яких лежать клініко-лабораторні показники, вік хворого, преморбідний фон (АРАCHЕ II, APACHE III) та шкали, які базуються на аналізі вираженості відхилень від фізіологічних показників, що характеризують ступінь функціональних системних розладів (SOFA, MOD). Але клініко-лабораторні показники та інші предиктори не можуть характеризувати глибину патологічних змін в організмі при септичному шоці. Основним недоліком їх є суб'єктивний підхід, неточність вимірів, обмеженість даних, що отримуються. Тому в нашому дослідження для створення моделі прогнозування ми використали шкали SOFA та APACHE II.

\section{МЕТА ДОСЛІДЖЕННЯ}

Прогнозування (створення математичної моделі) наслідків протікання септичного шоку 3 метою покращення якості їх лікування. Провести аналіз хворих 3 септичним шоком які знаходились на лікуванні у відділенні інтенсивної терапії та покращити якість лікування

\section{МАТЕРІАЛИ ТА МЕТОДИ}

Проведено математичний аналіз 102 історій хвороб хворих із сепсисом та 3 них 68 історій із септичним шоком, що знаходились на лікуванні у BAIT лікарні ім. М.І.Пирогова, в період 32016 по 2018 роки.

\section{РЕЗУЛЬТАТИ}

Ми дослідили динаміку індексів по шкалі оцінки важкості стану хворого SOFA (51 хворий), а також APACHE II (51 хворий) - для визначення вірогідності летальності. Оцінку проводили у перший день 
поступлення до стаціонару. Смертність склала 48 чоловік (47\%). При ретроспективному введені даних хворих у модель прогнозування смертності, отримали пряму кореляцію з нашими даними. А саме, за нашими даними, високий ступінь ризику $60-90 \%$ отримали $49 \%$ обстежених хворих, при цьому $0-30 \%$ - низький ризик, $30-60 \%$ - середній ризик летальності.

\section{ВИСНОВКИ}

Оцінка прогностичної здатності бальних шкал оцінки важкості APACHE II та SOFA показала, що у хірургічних хворих із септичним шоком, створена нами модель дозволяє прогнозувати ризик смертності і складає $0-30 \%-$ низький ризик, 30-60\% - середній ризик, $60-90 \%-$ високий ризик летальності.

\title{
Матвійчук М.С., Солощук М.О., Філонович Л.М., Іванютин А.В. КОМБІНОВАНА АНЕСТЕЗІЯ (СПІНО-ЕПІДУРАЛЬНА) ПРИ ОПЕРАЦІЇ ТОТАЛЬНОГО ЕНДОПРОТЕЗУВАННЯ КУЛЬШОВОГО СУГЛОБА
}

\author{
КЗ «КМЛШМД ДОР», м.Кам'янське, Україна
}

Тотальне заміщення кульшового суглоба $є$ рекомендованим для пацієнтів з кульшовим артрозом, у яких сильний біль не піддається фармакологічному та нефармакологічному лікуванню. На відміну від більшості інших операції, що супроводжується лише гострим болем, до заміщення кульшового суглоба пацієнтів спонукає спроба полегшити собі біль, який відчуває впродовж тривалого часу: місяців і років. Тому знеболювання цього оперативного втручання становить проблему як під час операції, так і після неї. Тотальне заміщення кульшового суглобу у пацієнтів, що зазнають хронічний біль вимагає адекватного знеболення.

\section{META РОБОТИ}

3'ясування ефективності спіно-епідуральної анестезії при тотальному ендопротезуванні кульшового суглобу у осіб похилого віку. Використання продовженої епідуральної анестезії в періопераційному періоді є чинником стреслімітованої відповіді організму на хірургічну травму та позитивно впливає на результати хірургічного лікування та може забезпечувати зменшення запальної відповіді.

\section{МАТЕРІАЛИ ТА МЕТОДИ ДОСЛІДЖЕННЯ}

Дослідження проводилось в Кам'янській МЛШМД в період 32015 по 2018 роки у 28 пацієнтів віком від 54 до 75 років (10 чоловіків, 18 жінок), яким було проведене первинне тотальне ендопротезування кульшового суглобу (ASA IIIII). Пацієнтам виконувалась комбінована спіно-епідуральна анестезія в сидячому положенні в проміжку L3-L4 серединним доступом 3 використанням набору Espocan («Bbraun», Німеччина) голкою G27 за методикою «голка крізь голку» 3 введенням 10-12 мг ( 2-2,4 мл) 0,5\% бупівакаїну. Післяопераційне знеболення постійна інфузія
$0,125 \%$ бупівакаїну 4 мл/год в епідуральний катетер за допомогою шприцевого насосу («Bbraun», Німеччина).

Інтенсивність болю за ВАШ вимірювали впродовж трьох діб у спокої та при рухах: у першу добу - через $3,6,9,12$ год, а у наступні три доби - вранці та ввечері.

\section{вИСНОВКИ}

Перевагою спіно-епідуральної анестезії при проведенні ендопротезування кульшового суглобу $є$ :

1. зниження ризику розвитку значної крововтрати.

2. зменшення ризику тромбоемболії, пневмонії та інсульту.

3. виключення згубного впливу на легені та ССС при загальному знеболенні, особливо в похилому віці і супутній патології.

4. зниження больової чутливості після завершення оперативного втручання.

5. зниженню летальності та скороченню часу перебування в стаціонарі.

Комбінована анестезія (спіно-епідуральна) за умови правильної техніки виконання та ретельного дозування анестетику не має клінічно значущих побічних ефектів і може бути рекомендованою для періопераційного та післяопераційного знеболення при тотальному ендопротезуванні кульшового суглобу у осіб похилого віку.

\section{СПИСОК ЛІТЕРАТУРИ}

Филиппенко В.А. Ендопротезирование тазобедренного сустава Под ред. В.А. Филиппенко, Н.А.Корж. - Х.: Коллегиум, 2015. -220

2. Глумчер Ф.С. «Руководство по интенсивной терапии»/ Ф.С.Глумчер, А.И.Тріщинський, А.В.Білясв, М.В. Бондарь/Київ, 2015.c.56-81.

\section{ГАЗОВІ МЕДІАТОРИ ОКСИД АЗОТУ ТА СІРКОВОДЕНЬ ЯК МАРКЕРИ ТЯЖКОСТІ ПОЛІТРАВМИ}

\author{
Львівський національний медичний університет імені Данила Галицького
}

\section{АКТУАЛЬНІСТЬ ПРОБЛЕМИ}

Сучасна тактика ведення пацієнтів 3 травмою базується на принципі попередження тих патологічних процесів в органах, системах, які розвиваються внаслідок прогресуючої гіпоперфузії і гіпоксії [1]. Пацієнти 3 ушкодженнями багатьох органів або систем клінічними проявами шоку є в групі ризику поліорганної недостатності та смерті. Ефективність відомих способів прогнозування із застосуванням різноманітних шкал $\epsilon$ обмеженою, оскільки вони в значній мірі мають суб'єктивну природу [2]. В останні роки як вітчизняні, так і зарубіжні дослідники приділяють велику увагу газовим медіаторам як маркерам тяжкості та прогнозу. До них відносять оксид азоту (NO) і сульфід водню $\left(\mathrm{H}_{2} \mathrm{~S}\right)[3,4]$.

\section{META РОБОТИ}

Оцінити роль оксиду азоту та сірководню для раннього встановлення тяжкості ушкодження та прогнозування перебігу політравми 3 позиції сучасних наукових даних.

\section{МАТЕРІАЛИ ТА МЕТОДИ}

Проведений аналіз даних клінічного обстеження i лікування 28 хворих 3 політравмою, доставлених у відділення анестезіології та інтенсивної терапії в середньому через 0,5 години після травми. Середній вік постраждалих складав $48,4 \pm 5,2$ років. Пацієнтам проводили лабораторні дослідження вмісту $\mathrm{H}_{2} \mathrm{~S}, \mathrm{NO}$ та його окиснених продуктів (NOx) в сироватці крові при госпіталізації та через 24 години інтенсивної терапії.

\footnotetext{
Матвійчук М.С., Солочук М.О., Філонович Л.М., Іванютин А.В., 2018

Матолінець Н.В. , 2018
} 


\section{РЕЗУЛЬТАТИ}

При достовірному зниженні від норми значень NO та NOx на момент госпіталізації до $0,35 \pm 0,02$ і $1,71 \pm 0,08$ мкмоль/л відповідно діагностували тяжку політравму. Середньотяжку політравму діагностували, коли вміст NO був достовірно знижений $(0,34 \pm 0,02$ мкмоль/л), а рівень $\mathrm{NOx}-$ близький до норми $(2,37 \pm 0,16$ мкмоль/л, $\mathrm{p}=0,003$ порівняно з групою тяжкої політравми). При госпіталізації середній рівень $\mathrm{H}_{2} \mathrm{~S}$ в сироватці крові пацієнтів обох груп був статистично значуще вищий від групи порівняння і досягав значень $64,5 \pm 1,41$ мкмоль/л ( $p=0,033$ до норми) $62,1 \pm 0,47$ мкмоль/л $(p=0,025)$, відповідно. Відмінності між групами тяжкої та середньотяжкої травми не були статистично значущими $(p=0,117)$.

\section{вИСновкИ}

Визначення рівня газотрансмітерів як біомаркерів в гострому періоді політравми може служити вірогідним критерієм для покращення точності ранньої діагностики та об'єктивного прогнозу тяжкості її перебігу.

Ключові слова: травма, газотрансмітери, критерії діагностики, прогноз

\section{СПИСОК ЛІТЕРАТУРИ}

Advanced trauma life support $\left(A T L S^{\circledR}\right)$ : the ninth edition. ATLS Subcommittee; American College of Surgeons' Committee on Trauma; International ATLS working American College of Surgeons Committee on Trauma; International ATLS working group Chaplean W, Al-hhatib J, Haskin D [el al.] / J. T3ana Acule Care Surg. -

2. Математичне моделювання впливу чинників ризику на вірогідність несприятливого результату при тяжкій черепно-мозковій травмі В.М.Шевага, А. В.Паєнок, В. В.Білошичький, Б.В.Задорожна, А.М.Нетлюх, О.Я. Кобилецький, Т. Г. Гутор, Д. В. Щибовик // Вісник наукових досліджень. 2016. - № 4. - C. 46-48

Роль газотрансмітерів у патогенезі органної дисфункиії при політравмі Матолінець Н.В. // Медицина неотложных состояний. - 2018. - №3(90). Матолінец

4. Nitric oxide as an indicator for severity of injury in polytrauma / E. Beitl, A. Banasova, M. Vlcek, D. Mikova, V. Hampl // Bratislava Medical Journal. - 2016. - Vol.116, No.4. - p.217-220. PMID:27075385.

\title{
МЕНЕДЖМЕНТ ДИХАЛЬНИХ ШЛЯХІВ ТА ЯКІСТЬ ВІЗУАЛІЗАЦІЇ ПЛЕВРАЛЬНОЇ ПОРОЖНИНИ ПРИ ВТРУЧАННІ ЗА NUSS
}

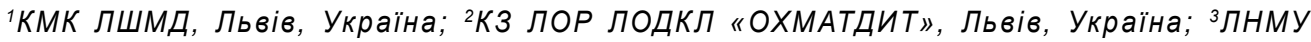

ім. Д.Галицького, Львів, Україна

\section{АКТУАЛЬНІСТЬ}

Проведення торакоскопічної корекції лійкоподібної деформації грудної клітки за Nuss передбачає колабування легенів для візуалізації операційного поля. Цього можна досягнути застосувавши роздільну вентиляцію легень без створення додаткового тиску в плевральній порожнині або шляхом постійної інсуфляції $\mathrm{CO}_{2}$ із підвищеним внутрішньо-плевральним тиском.

\section{META}

Дослідити залежність якості візуалізації операційного поля від різних методів досягнення колабування легенів при операціях за Nuss.

\section{МАТЕРІАЛИ ТА МЕТОДИ}

В дослідження було включено 24 дітей з лійкоподібною деформацією грудної клітини віком $14.6 \pm 0.53$ років. Дітей рандомізовано в дві групи залежно від методу забезпечення прохідності дихальних шляхів та досягнення колабування легенів: група 1 (n=12), в якій візуалізація плевральних порожнин отримана шляхом накладання напруженого пневмотораксу інсуфляцією $\mathrm{CO}_{2}$ при забезпеченні прохідності дихальних шляхів однопросвітною інтубаційною трубкою відповідного розміру та група $2(\mathrm{n}=12)$, в якій отримано відкритий пневмоторакс без додаткового тиску в плевральній порожнині, при роздільній вентиляції легень через двопросвітну лівосторонню інтубаційну трубку. Інтраопераційно проведено моніторинг $\mathrm{SpO}_{2}$, параметрів вентиляції (об'єм вдиху, тиск на вдосі, еtCO ${ }_{2}$. Оцінка якості візуалізації операційного поля виконувалась хірургом за п'ятибальною шкалою (залежно від колабування легені від найгіршої - 1 до максимальної візуалізації - 5) в момент введення камери в плевральну порожнину, проведення корегуючої пластини за грудиною та провертання із фіксацією пластини до ребер.

\section{РЕЗУЛЬТАТИ}

$\mathrm{SpO}_{2}$ становила на момент розрізу шкіри в групі $1-98.8 \%$, в групі $2-98.5 \%$ ( $\mathrm{p}=0.3)$; на етапі колабування легенів: в групі $1-98.6 \%$, в групі $2-98.0 \%(\mathrm{p}=0.2)$; на етапі повороту пластини: в групі $1-98.8 \%$, в групі $2-96.7 \%(\mathrm{p}=0.1)$. Такий рівень оксигенації забезпечувався $\mathrm{FiO}_{2}=0.6$ в обох групах. Об'єм вдиху становив на момент розрізу шкіри в групі $1-278$ мл, в групі $2-330$ мл ( $\mathrm{p}=0.15)$; на етапі колабування легенів: в групі $1-240$ мл, в групі $2-221$ мл $(\mathrm{p}=0.35)$; на етапі повороту пластини: в групі $1-267$ мл, в групі $2-301$ мл $(\mathrm{p}=0.3)$. Рівень еtCO становило на момент розрізу шкіри в групі $1-35.2$, в групі $2-35.5(\mathrm{p}=0.45)$; на етапі колабування легенів: в групі $1-38.8$, в групі $2-40.7$ $(\mathrm{p}=0.23)$; на етапі повороту пластини: в групі $1-47.6$, в групі 2 - 41.0 ( $\mathrm{p}=0.07)$. Якість візуалізації операційного поля хірурги оцінили наступним чином: на початку операції в групі $1-3.8$, в групі $2-4.5(\mathrm{p}=0.04)$; на етапі проведення пластини: в групі $1-3.4$, в групі $2-4.5$ $(\mathrm{p}=0.01)$; на етапі повороту та фіксації пластини: в групі $1-3.6$, в групі $2-4.7(\mathrm{p}=0.04)$.

\section{ВИСНОВКИ}

Роздільна вентиляція легенів через двопросвітну лівосторонню трубку забезпечує кращу візуалізацію операційного поля порівняно з інсуфляцією $\mathrm{CO}_{2}$ та вентиляцією крізь однопросвітну трубку при торакоскопічних операціях за Nuss. Параметри вентиляції та $\mathrm{SpO}_{2}$ в обох групах статистично не відрізнялись.

Нестеренко А.Н., Прокопенко Б.Б., Климик Н.А., Нестеренко Е.А. ДИНАМИКА ЧУВСТВИТЕЛЬНОСТИ ЕSКАРЕ-ПАТОГЕНОВ - ВОЗБУДИТЕЛЕЙ ГОСПИТАЛЬНОЙ ХИРУРГИЧЕСКОЙ ИНФЕКЦИИ ЗА ДВУХЛЕТНИЙ ПЕРИОД ЛОКАЛЬНОГО МИКРОБИОЛОГИЧЕСКОГО МОНИТОРИНГА В СТАЦИОНАРАХ КРАМАТОРСКА

Донецкий национальный медицинский университет МЗ Украины, Краматорск

ЦЕЛЬ

Определить приоритетные препараты для стартовой эмпирической антибактериальной (АБ) терапии госпи- тальной ESKAPE-инфекции в конкретных отделениях хирургического профиля (ОХП) городских клинических больниц (ГКБ) Краматорска.

\footnotetext{
Мигаль I.І., Альбокрінов А.А., Фесенко У.А., 2018

Нестеренко А.Н., Прокопенко Б.Б., Климик Н.А., Нестеренко Е.А., 2018
} 
МАТЕРИАЛЫ И МЕТОДЫ

Выполнено нерандомизированное ретроспективное (VII.2015-VI.2017) эпидемиологическое исследование результатов локального микробиологического мониторинга (ЛММ) - высевов 1738 изолятов патогенов, в том числе 479 изолятов: Staphylococcus aureus, Klebsiella pneumoniae, Acinetobacter baumannii, Pseudomonas aeruginosa, Enterobacter spp (ESKAPE) в отделяемом ран, дренажей пациентов 1-2 хирургических отделений (110 коек) ГКБ №1; травматологического, ожогового отделений (80 коек) ГКБ №3; хирургического (50 коек) отделения онкологического диспансера г. Краматорска, взятых спустя 48 часов после госпитализации с выделением изолятов в количестве не менее $10^{5} \mathrm{KOE} /$ мл. Использовали диско-диффузионный и метод серийных разведений с использованием системы VITEK $^{\circledR} 2$ compact (bioMerieux Inc) с компьютерной обработкой (WHONET,v.5.6). Чувствительность патогенов к АБ-препаратам учитывали, если данные были представлены в $\geq 75 \%$ наблюдений

\section{РЕЗУЛЬТАТЫ}

Среди выделенных ESKAPE-патогенов за периоды VII.2015VI.2016 / VII.2016-VI.2017 доминировал MRSA (S. aureus) $(66+103)=169$ высевов с чувствительностью к тобрамицину (Тоб) $84,6 / 100 \%$; амикацину (Амк) -/93,8\%; гентамицину (Ген) $-/ 83,3 \%$; клиндамицину (Кли) $72 / 83,3 \%$; ванкомицину (Ван) 69,2/75,8\%; левофлоксацину (Лвф) -/41,2\%; меропенему (Мер) -/15,8\%; имипенему (Ипм) -/11,8\%. На II месте A. baumannii - $(72+72)=144$ высева с чувствительностью: к Ген 100/66,7\%; Тоб 79,4/84,6\%; Амк 55,6/83,3\%; Лвф 56,8/ $51,7 \%$; Мер 41,7/88,9\%; Ипм 33,3/56\%; цефтриаксону (Цтр)
$23,8 / 45,9 \%$. Ha III - Enterobacter spp $(30 / 30)=60$ высевов с чувствительностью: к Ген 90/83,3\%; Амк 38,5/ $80 \%$; Мер 50/88,9\%; Цтр 35,3/44,4\%; Имп 20/50\%. На IV - K. pneumoniae $(35+22)=57$ высевов с чувствительностью: к Ген $100 / 75 \%$; Амк $64,3 / 55,6 \%$; Тоб $60 / 75 \%$; Mep 60/62,5\%; Лвф 41,2/42,9\%; Цтр 50/41,7\%. На V Ps. aeruginosa $(31+18)=49$ высевов с чувствительностью: к Тоб 83,3/-\%; Ген 75/-\%; Цтр 56,2/50\%; Мер $42,9 / 57,1 \%$; Лвф 42,1/75\%; Ипм 40/12,5\%. E.faecium высеян не был. Двухлетний ЛММ ОХП ГКБ Краматорска позволил выявить среди госпитальных патогенов существенную $(27,6 \%)$ долю проблемных ESKAPEпатогенов. На основании ЛММ производили выбор АБпрепаратов с чувствительностью к ним патогенов $>70 \%$ для стартовой эмпирической АБ-терапии.

\section{выводы}

ЛММ ОХП позволил выявить клинически значимые возбудители госпитальной хирургической инфекции, степень их АБ-резистентности и послужил основанием выбора препарата или их комбинации для стартовой эмпирической АБ-терапии.

\section{СПИСОК ЛИТЕРАТУРЫ} David R. Jenkins. Nosocomial infections and infection control.
Medicine. 2017; V. 45, P. 629-633.

2. Sartelli M., Chichom-Mefire A., Labricciosa FM. et al. The managemen of intra-abdominal infections from a global perspective: 2017 WSES guidelines for management of intra-abdominal infections. World Journal of Emergency Surgery. 2017; V.12, P.1-34.

3. Нестеренко О.М., Щербина Ю.В., Бойцун I.М. та ін. Сучасні підходи ка спричинена Acinetobacter baumannii mа інтенсивна mерапія.- 2015.- № 2(6).- C. 28-37.

\title{
Павленко Г.В., Коляда В.Н., Савенков Д.Ю., Макаренко В.В., Кравцова Е.А., Панченко Ю.Ю. \\ СЛУЧАЙ УСПЕШНОЙ КОНСЕРВАТИВНОЙ ОСТАНОВКИ КРОВОТЕЧЕНИЯ ИЗ ПАНКРЕАТО-ГАСТРОАНАСТОМОЗА ПОСЛЕ ПАНКРЕАТО- ДУОДЕНАЛЬНОЙ РЕЗЕКЦИИ (ПДР)
}

\author{
КУ «Клинический онкологический диспансер» ДОС», ОАИТ. г. Днепр, Украина.
}

Наиболее частыми вариантами анастомозов с поджелудочной железой (ПЖ) являются панкреато-еюно- и панкреатогастороанастомозы (ПГА). Оба имеют преимущества и недостатки. Основным недостатком ПГА является эрозивное кровотечение со среза ПЖ

\section{ЦЕЛЬ}

Оценить возможность консервативной остановки кровотечения из ПГА после ПДР.

\section{МАТЕРИАЛЫ И МЕТОДЫ}

Пациент Ш., 48лет, с DS: Susp. c-r дистальной трети холедоха с инвазией в нижнюю полую вену выполнено оперативное лечение в объме ПДР с формированием ПГА, краевая резекция нижней полой вены под комбинированной анестезией с ИВЛ. Перед операцией катетеризировано эпидуральное пространство на уровнне TVII-TVIII. Гипнотический эффект по ходу операции достигался ингаляцией севорана 1,5-2 л/мин, анальгезия - эпидуральной блокадой лонгокаином $0,25 \%$ со скоростью 4 мл/час, релаксация ардуаном в стандартной дозировке. Интраоперационно проводилась перфузия октры (4мл/ 8 ч), омепразол 80 мг, контривен 250 тысяч, антибактериальная терапия, инфузионно-трансфузионная терапия. Интраоперационная кровопотеря 400мл.

В ОИТ проводилась антибактериальная и противогрибковая терапия, блокаторы протонной помпы (омепразол 120мг в сут), октра 6мл в сутки (перфузор), контривен 250 тыс дважды, инфузионно-трансфузионная терапия, включающая сбалансированные кристаллоиды, альбумин 10\% 200мл; гепатопротекторная терапия, профилактические дозировки НМГ (клексан 0.2 мл). Анальгезия обеспечивалась путем продленной эпидуральной блокады лонгокаином $0,25 \%$ 4мл/час и внутривеннным введением ксефокама 8мг 2 раза в сут.

Ранний послеоперационный период протекал гладко, на 2-е сутки больной в удовлетворительном состоянии был переведен в ХО.

На 8-ые сутки у больного развилось кровотечение из ПГА. Проведена гемостатическая терапия: этамзилат $12,5 \%$ - 6 мл, сангера 1000 мг, прием per os охлажденной аминокапроновой кислоты с адреналином, заместительная инфузионнотрансфузионная терапия.

С учетом продолжающегося кровотечения больной переведен в ОИТ, где назначено болюсное в/венное введение реместипа 1000 мкг 6 раз в сут. (3 мкг/кг/час), гемостатическая терапия сангерой, этамзилатом, контролок 160 мг/сут. и октра 6мл/сут. (перфузор).

Через 24 часа от начала терапии реместипом кровотечение было остановлено. Терапия продлена до 72 ч в прежнем режиме.

\section{РЕЗУЛЬТАТЫ}

На 5-ые сутки от начала кровотечения больной в удовлетворительном состоянии переведен в ХО, на 12-ые - выписан на амбулаторное наблюдение хирургом.

\section{выводы}

Своевременное использование реместипа, как компонента комплексной гемостатической терапии, позволило избежать повторного хирургического вмешательства, обеспечить быструю реабилитацию и выписку больного со стационара. 


\title{
Пальжок А.Д. Артеменко В.Ю., Андреева С.Н. В ПОИСКАХ ОПТИМАЛЬНОГО ДОСТУПА ДЛЯ ПРОВЕДЕНИЯ ПРОДЛЁННОЙ ИВЛ В УСЛОВИЯХ ОТДЕЛЕНИЯ АИТ
}

\section{ВВЕДЕНИЕ}

В современной литературе продолжается спор о преимуществах различных методик проведения трахеостомии [1]. Трахеостомия обоснована, если ее выполнение улучшает состояние больного и предупреждает возможные осложнения заболевания.

\section{ЦЕЛЬ ИССЛЕДОВАНИЯ}

Проанализировать собственный трехлетний опыт в обеспечении доступа к дыхательным путям для проведения продлённой ИВЛ.

\section{МАТЕРИАЛ И МЕТОДЫ}

В ОАИТ клиники ИНТО-САНА за период 2014-2017 г. выполнено 28 трахеостомий. Трахеостому накладывали на 7-10 сутки интубированным больным, если предполагалась продленная ИВЛ [2].

1 группа - проведена чрезкожная пункционно-дилятационная трахеостомия (ЧПДТ) - 21 человек.

2 группа - трахеостомия хирургическим (XT) методом 7 человек. Эти пациенты имели ИМТ более 35 кг/м², короткую шею или увеличеную щитовидную железу.

ЧПДТ проводились по методу Cliaglia в плановых условиях на фоне эндотрахеальной интубации под местной анестезией, седацией, и при видеоэндоскопической ассистенции. ХТ проводилась приглашаемым ЛОР врачом.

Из осложнений при выполнении ЧПДТ:

У 1 больного наложение ЧПДТ заняло 20 мин, что было связано с недостаточными практическими навыками оператора и не повлекло каких-либо последствий.

Из осложнений при открытой ХT:

Нагноение послеоперационной раны - 1 случай;

Кровотечение из раны - 1 случай;

Подкожная эмфизема - 1 случай;
Осложнения в 1 группе зарегистрированы в 1 случае $(4,5 \%)$. Во 2 группе - в 3 случаях $(43 \%)$. Ни один случай осложнений после выполнения трахеостомии, обоими методами, не привёл к фатальным последствиям, но их лечение повлекло дополнительные расходы.

\section{РЕЗУЛЬТАТЫ И ОБСУЖДЕНИЕ}

ЧПДТ является методом выбора в ОАИТ, так как характеризуется минимальной травматичностью, простой техникой и быстротой выполнения. Технология ЧПДТ предполагает плотное прилегание канюли к краям раны, что снижает риск инфекции послеоперационной раны и возникновения кровотечений. Техника исполнения не вызывает трудностей в обучении персонала ОАИТ. У пациентов, которых удалось деканюлизировать, рубец после ЧПДТ меньше и имеет косметические преимущества. Имеется экономическая выгода при использовании методики ЧПДТ[3].

\section{выводы}

1. При ЧПДТ меньше осложнений как гнойно-септических так и кровотечений.

2. ЧПДТ более комфортна для выполнения анестезиологами.

3. После ЧПДТ остается меньше косметических дефектов.

4. ЧПДТ позволяет экономить средства, затрачиваемые на борьбу с осложнениями.

\section{СПИСОК ЛИТЕРАТУРЫ}

1. Percutaneous Versus Surgical Tracheostomy: A Randomized Controlled Study With Long-Term Follow-Up. W. Silvester, MD, FRACP, Crit Care Study With Long-Term Follow-
Med. 2006;34(8):2145-2152.

2. Трахеостомия у нейрохирургичеких больных (Показания к операции, методика трахеостомии, уход). М.С. Фокин, А.С. Горячев. Москва 2007

3. Consensus conference on artificial airways in patients receiving mechanical ventilation. Hummer A. L., Gracey D. R Chest 1989; 96 (1)

\section{Перова-Шаронова В.М. ${ }^{1}$, Альбокрінов А.А. ${ }^{1}$, Фесенко У.А. ${ }^{2}$ ПОРУШЕННЯ МЕЗЕНТЕРІАЛЬНОГО КРОВОПЛИНУ ПРИ ІНТРААБДОМІНАЛЬНІЙ ГІПЕРТЕНЗІЇ У ДІТЕЙ}

\author{
1 КЗ ЛОР ЛОДКЛ “ОХМАТДИТ», Львів, Україна \\ 2 ЛНмУ ім. Д.Галицького, Львів, Україна
}

\section{АКТУАЛЬНІСТЬ}

Інтраабдомінальна гіпертензія (ІАГ) призводить до зниження абдомінального перфузійного тиску та порушує мезентеріальний кровоплин.

\section{META}

Дослідити залежність МК від рівня інтраабдомінального тиску (IAT) та вплив методів післяопераційного знеболювання на МК у дітей з ІАГ.

\section{МАТЕРІАЛИ ТА МЕТОДИ}

В дослідження було включено 42 дитини 3 IАГ у післяопераційному (ПО) періоді віком 5-13 років, після оперативних втручань з приводу гострого гангренозноперфоративного апендициту, перитоніту. Дітей було рандомізовано на три групи в залежності від методу ПО знеболювання («ЕДА», $\mathrm{n}=14$; «Лідокаїн», $\mathrm{n}=13$; «Опіӧ̈ди», $\mathrm{n}=15 ;$;). В ПО періоді діти групи «ЕДА» отримували пролонговану епідуральну інфузію $0.25 \%$ розчину бупівакаїну 0.4 мг/кг/год. Дітям групи «Лідокаїн» проводилась прологована внутрішньовенна інфузія $1 \%$ розчину лідокаїну 1.5 мг/кг/г. Діти групи «Опіӧ̈ди» отримували внутрішньовенну інфузію морфіну 10 мкг/кг/г. Усім дітям проводилось вимірювання IAT стандартним непрямим методом через сечовий міхур та об'ємної швидкості кровоплину у верхній мезентеріальній артерії за допомогою ультразвуку.

\section{РЕЗУЛЬТАТИ}

Спостерігалась статистично значуща сильна негативна кореляція $(\mathrm{r}=-0.73, \mathrm{pB} 0.05)$ між показниками IAT та обгємною швидкістю МК. В групах «Лідокаїн» та «ЕДА» спостерігалась тенденція до зниження IAT у порівнянні з групою «Опіоїди». Об'ємна швидкість МК

\footnotetext{
- Пальжок А.Д. Артеменко В.Ю., Андреева С.Н., 2018

- Перова-Шаронова В. М., Альбокрінов А. А., Фесенко У. А., 2018
} 
MATERIALS OF THE CONGRESS OF ANAESTHESIOLOGISTS OF UKRAINE September 13-15, 2018

в групі «ЕДА» була статистично значуще вищою у порівнянні із групою «Опіоїди», та спостерігалась Таблиця 1. Середні показники IAT та об'ємної швидкості МК в групах

\begin{tabular}{|c|c|c|c|c|}
\hline Групи & «Лідокаїн» & «ЕДА» & «Oпіоїди» & $\mathbf{P}$ \\
\hline $\begin{array}{l}\text { IAT (мM Hg) } \\
M \pm S D\end{array}$ & $9.28 \pm 2.13$ & $9.23 \pm 2.97$ & $11.14 \pm 2.15$ & $\begin{array}{l}\text { Л vs E } 0.37 \\
\text { Л vs O } 0.06 \\
\text { Evs O } 0.07\end{array}$ \\
\hline $\begin{array}{l}\text { Об'ємна } \\
\text { шв идкість } \\
\text { кров оплину } \\
\text { (мл/хв) } \\
\text { Ме (Q1;Q3) }\end{array}$ & $\begin{array}{r}232.50 \\
(141.06 ; \\
405.51)\end{array}$ & $\begin{array}{r}255.57 \\
(136.21 ; \\
442.08)\end{array}$ & $\begin{array}{c}56.63 \\
(44.25 \\
107.41)\end{array}$ & $\begin{array}{r}\text { Л vs E } 0.8 \\
\text { Л vs O } 0.08 \\
\text { E vs O } 0.04\end{array}$ \\
\hline
\end{tabular}

PAIN, ANAESTHESIA \& INTENGIVE CARE N 32018

тенденція до його збільшення у групі «Лідокаїн»в порівнянні із групою «Опіоїди». Основні результати дослідження наведені у Таблиці 1.

\section{ВИСНОВКИ}

ІАГ призводить до порушення МК. МК обернено пропорційний рівню IAT. Епідуральна анестезія при ІАГ покращує МК.

\section{СПИСОК ЛІТЕРАТУРИ}

Perko MJ Duplex ultrasound for assessment of superior mesenteric artery blood flow. Eur J Vasc Endovasc Surg. 2001;21(2):106-17.

2. Avital S, Szomstein S, Brasesco OE, Rosin D, Paolucci P, Pishori TI, Thaler K, Mailapur R, Sands LR, Wexner SD, Rosenthal RJ. Changes in mesenteric blood flow during intracranial hypertension due to acute elevations in intra-abdominal pressure. Therapy 2005;2(4):603-7.

3. Kirkpatrick AW, McBeth PB, Ball CG, Ejike JC, De Laet IE, Nickerson D. Mesenteric ischemia, intra-abdominal hypertension, and the $24(1): 9-10$

\section{ПОКРИШЕНЬ Д.О. \\ THRIVE В ЯКОСТІ ОСНОВНОГО МЕТОДУ РЕСПІРАТОРНОÏ ПІТРИМКИ ПІД ЧАС МІКРОЛАРИНГОХІРУРГІЇ}

\section{ДУ «Інститут отоларингології ім. профр. О.С.Коломійченка НАМН України»}

В 2015 році в клінічну практику запровадили нову методику респіраторної підтримки - THRIVE для забезпечення оксигенації у пацієнтів на етапі індукції анестезії до встановлення надійного контролю над складними дихальними шляхами [1]. Водночас, переваги методики в мікрохірургії гортані настільки очевидні, що iii практично відразу почали використовувати як основний метод респіраторної підтримки при даних втручаннях $[1,2,3,4]$.

THRIVE (Transnasal Humidified Rapid-Insufflation Ventilatory Exchange) - полягає у подаванні пацієнту великих об'ємів зволоженого та теплого кисню через широку носову канюлю, що забезпечує повноцінну оксигенацію та дозволяє сповільнити розвиток гіперкапні під час апное. Ефективність методики підтверджена у пацієнтів різних вікових та клінічних груп $[4,5,6]$.

Важливим $є$ використання зволожувачів, які дозволяють підтримувати $100 \%$ вологість та температуру $35-37^{\circ} \mathrm{C}$ навіть при використанні потоку О до 70л/хв [1,7]. Дані зволожувачі не є специфічними для даної методики і широко використовуються під час інших режимів ШВЛ, в тому числі в Україні.

Постійне підтримання прохідності верхніх дихальних шляхів є принциповим для успішного застосування THRIVE. Навіть короткочасна обструкція верхніх дихальних шляхів буде призводити до десатурації.

THRIVE не можна розглядати як метод лікування дихальної недостатності та гіпоксії, а виключно як короткочасний (до 30-40 хв) спосіб підтримання оксигенації та відтермінування гіперкапнії. При зниженні $\mathrm{SpO}$ до $90 \%$ і нижче слід негайно переходити на більш ефективний метод респіраторної підтримки.

Існують також інші обмеження та протипоказання $[1,6,7]$. Проведено аналіз загальних анестезій з використанням THRIVE під час мікроларингохірургії у 17 пацієнтів віком від 7 до 45 років. Середній вік становив $25,17 \pm 14,7$ років. Послідовність дій під час виконання зазначеної методики цілком відповідала алгоритму описаному її розробниками і полягала в наступному [1, 7]:

1. До початку індукції анестезії протягом 5 хв. подавали зволожений і теплий кисень через носову канюлю зі швидкістю 20-30 л/хв.

2. Після індукції анестезії (пропофол, фентаніл, атракуріум) потік $\mathrm{O}_{2}$ збільшували до 70 л/хв. У дітей: $2 \pi / \kappa г /$ Хв [4]
3. Протягом 1 хв. проводили ШВЛ через лицеву маску для оцінки вихідного РеtCO

4. До початку встановлення опорного ларингоскопа прохідність верхніх дихальних шляхів підтримували шляхом виведення нижньої щелепи.

5. Зволожений теплий $\mathrm{O}$ подавали через носову канюлю протягом всього втручання.

6. Після завершення операції та видалення ларингоскопа подачу $\mathrm{O}_{2}$ через ніс припиняли і встановлювали LMA для проведення традиційної ШВЛ на етапі пробудження.

Середня тривалість втручання склала $22,82 \pm 7,00$ хв. Ускладнення, пов'язані з анестезією і вентиляцією не спостерігались, і всі пацієнти були виписані із стаціонару в задовільному стані.

Значення $\mathrm{SpO}_{2}$ під час загальної анестезії становило 99$100 \%$ у 16 пацієнтів. У одного пацієнта на 12 хв. втручання спостерігали зниження $\mathrm{SpO}_{2}$ до $92 \%$, що призвело до переходу на надскладкову струминну ШВЛ з відновленням значення $\mathrm{SpO}_{2}$ до 100\% протягом 1 хв.

Середні значення РеtCO до початку втручання, після завершення THRIVE та після завершення ШВЛ через LMA становили $37,05 \pm 4,72,52,17 \pm 6,27$ та $39,94 \pm 5,20$ мм рт. ст. відповідно. Зростання РеtCO $є$ характерним для даної методики, є невід'ємною іiї частиною і швидко нормалізується на фоні традиційної ШВЛ.

Застосування THRIVE очевидно є доцільним під час мікрохірургії гортані.

\section{СПИСОК ЛІТЕРАТУРИ}

1. Patel A, Nouraei SAR. Transnasal Humidified Rapid-Insufflation Ventilatory Exchange (THRIVE): a physiological method of increasing apnoea time in patients with difficult

2. BucsitF. THRIVE-ing With Optiflow During Endoscopic Microlaryngeal Surgery / F. Bucsit, L. Tan, W. Bin, E. Seet // Difficult Airway Society: Annual Scientific Meeting (16-

3. Valdinger S. Microlaryngoscopy and Transnasal Humidified Rapid-insufflation Ventilatory Exchange (THRIVE) - A Case Series / S. Valdinger, A. Norris, H. Sycamore, D. Evans, S. Evans// Difficult Airway Society: Annual Scientific Meeting (22-24th

4. Saini R. An Audit of High-flow Nasal Oxygen for Microlaryngoscopy and Bronchosocopy in Paediatrics / R. Saini, Sung-Min Jung, R. Hewitt, R. Nand // Difficult Airway Society: Annual Sci
$P .30$. No48

5. Gustafsson I. Apnoeic Oxygenation In Adults Under General Anaesthesia Using Transnasal Humidified Rapid-Insufflation Ventilatory Exchange (THRIVE) , Society. Annual Scientific Meeting (16-18th November 2016, Torquay) Abstracts: 2016. - P.13№16

6. Humphreys S. et al. Transnasal humidified rapid-insufflation ventilatory exchange Humphreys $S$. et al. Transnasal humidified rapid-insufflation ventilatory exchange
(THRIVE) in children: a randomized controlled. British Journal of Anaesthesia.-2017, $118(2): 232-8$

Millette BH, Athanassoglou V., Patel A. High flow nasal oxygen therapy in adult anaesthesia. Trends in Anaesthesia and Critical Care - 2018, 18: 29-33. 


\title{
Полінчук І.С., Гардубей Є.Ю., Малахов П.С., Полінчук І.М., Сидорко Ю.В., Туряниця С.В., Цимбал Ю.Ф., Арбузова В.О., Степаненко П.П. СУЧАСНА ПАРАДИГМА АНЕСТЕЗІОЛОГІЧНОЇ БЕЗПЕКИ
}

Херсонська міська клінічна лікарня ім. Є.Є.Карабелеша

\section{АКТУАЛЬНІСТЬ ПРОБЛЕМИ}

Кількість ускладнень, що закінчились смертю пацієнта: у Великій Британії - 1 на 185000 анестезій, США - 1:200000, Австралії - 1:26000, Франції - 1:13000, Данії - 1:2500 [1]. Прогнозування і профілактика ускладнень - запорука безпеки пацієнтів, що і стало приводом для проведення дослідження.

\section{META РОБОТИ}

Підвищення безпеки пацієнтів в періопераційному періоді в плановій хірургії. Для досягнення цієї мети поставлені завдання: визначити безпечний обсяг обстежень перед плановим оперативним втручанням, категорії пацієнтів, яких можна безпечно оперувати під загальною або провідниковою анестезією в стаціонарі одного дня (СОД), критерії безпечної виписки пацієнтів додому із СОД, вивчити епідеміологію ожиріння в плановій хірургії.

\section{МАТЕРІАЛИ ТА МЕТОДИ}

Дослідження проведено у ВАІТ КЗ «ХМКЛ ім. Є.С.Карабелеша» у 2007-2017 pp., використані лабораторні, клінічні, психофізіологічні (тест Халстеда-Рейтана), статистичні методи, методика статусметрії по Шифрину Г.А. [2].

\section{РЕЗУЛЬТАТИ ТА ОБГОВОРЕННЯ}

Проведено дослідження прогнозованих та непрогнозованих періопераційних ускладнень. Створено та затверджено наказом по лікарні Локальний клінічний протокол (ЛКП) «Стандарт обстеження пацієнтів перед плановим оперативним втручанням» (2008), який включає різнобічні дослідження, консультації суміжних фахівців, тромбопрофілактику.

Визначені безпечні межі лікування в умовах СОД. Статусметрія використана (до та через 6 год. після операції) для оцінки стану 335 пацієнтів (18-84 роки), що були прооперовані з приводу: пахових та пупкових гриж (n=143), варикозної хвороби нижніх кінцівок $(\mathrm{n}=102)$, геморою $(\mathrm{n}=90)$. Результати показали, що в умовах СОД з високим рівнем безпеки можна оперувати пацієнтів з системними розладами I-II класу за шкалою ASA.

Проведено дослідження, результатом якого стала розробка інтегральної Шкали безпечної виписки (ШБВ), що також формалізована у вигляді ЛКП та Пат. UA №45910 А61К 9/00. Технологія ШБВ, що розроблена для СОД, ефективно використовується і в інших випадка, наприклад, при вирішенні питання про виписку пацієнтів після ендоскопічних досліджень (ФЕГДС, ФКС) під загальною анестезією.

Досліджено поширеність ожиріння, як предиктора періопераційних ускладнень, у планових хірургічних пацієнтів $(\mathrm{n}=959)$, нормальну масу тіла мали $22,42 \%$ чол., ожиріння I ст. - $22,73 \%$, II - 29,72\%, III - $18,04 \%$, IV $7,09 \%$.

\section{ВИСНОВКИ}

1. Обсяг досліджень перед плановим оперативним втручанням повинен максимально убезпечити пацієнта протягом періопераційного періоду.

2. В умовах СОД з високим рівнем безпеки можна оперувати пацієнтів 3 системними розладами I-II класу за шкалою ASA.

3. ШБВ - ефективна методика для умов СОД.

4. Поширеність ожиріння серед планових хірургічних пацієнтів - 77,58\%, що вимагає проведення тромбопрофілактики.

\section{СПИСОК ЛІТЕРАТУРИ}

Айткенхенд А. Поддержание стандартов лечения и ответственность анестезиолога // Актуальные проблемы анестезиологии и реаниматологии. Освежающий курс лекций, пер. с англ., Архангельск-Тромсё, 1997.- С. 17-24.

2. Шифрин Г.А. Организация и стандартизация интенсивной терапии и обезболивания. Практическое руководство.- 3.: ВПК «Запоріжжя», 2001.- 80 c.

\section{ПРОБЛЕМА СКЛАДНОЇ ІНТУБАЦІЇ ТРАХЕЇ В АНЕСТЕЗІОЛОГІЧНІЙ ПРАКТИЦІ}

\author{
Херсонська міська клінічна лікарня ім. Є.Є.Карабелеша
}

\section{АКТУАЛЬНІСТЬ ПРОБЛЕМИ}

Складна інтубація трахеї (CIT) - актуальна проблема анестезіологічної практики. Частота СІТ - 3:1000 (наказ MO3 України від 03.07.2006 №430 - Клінічний протокол надання медичної допомоги хворим зі складною інтубацією трахеї), за даними M.Janssens (2000): в хірургії $4 \%$, акушерстві - $8 \%$.

\section{META РОБОТИ}

Підвищення якості медичної допомоги пацієнтам хірургічного профілю шляхом прогнозування та вирішення проблеми CIT. Поставлені завдання: вивчити структуру пацієнтів планової хірургії за предикторами CIT, якими є вік, індекс маси тіла (IMT), фізичний статус, деякі анатомо-топографічні показники; порівняти прогнозовану кількість СIT з фактичною, з'ясувати наявність гендерного предиктора СIT, проаналізувати ефективність деяких технологій при CIT.

\section{МАТЕРІАЛИ ТА МЕТОДИ}

Дослідження проведено у ВАІТ КЗ «ХМКЛ ім. Є.Є.Карабелеша» у 2014 - 2017 pp. 3 використанням методів епідеміологічного, демографічного, статистичного аналізів. За цей час прооперовано 959 чол. 3 приводу хронічного калькульозного холециститу, вентральної грижі. IMT визначали за формулою: $\mathrm{m}$ (кг) $/ \mathrm{h}^{2}$ (м), фізичний статус пацієнтів - за шкалою ASA: I - здоровий пацієнт; II - легкі системні захворювання (IMT 30-40); III - субкомпенсовані системні захворювання (IMT $\geq 40$ ); IV - декомпенсовані системні захворювання; анатомотопографічні показники - за шкалою Mallampati, тіроментальною дистанцією (ТМД), $\mathrm{N}-$ не $<6,5$ см, стерноментальною дистанцією (СМД), $\mathrm{N}-$ не $<12,5 \mathrm{~cm}$. При СIT були використані: інтубація трахеї при збереженій свідомості; різні за розмірами клинки ларингоскопа, BURP-маневр, фібробронхоскопія (ФБС).

\section{РЕЗУЛЬТАТИ ТА ОБГОВОРЕННЯ}

Всього пацієнтів - 959 чол.: 237 чоловіків (24,71\%), 722 жінок $(75,29 \%)$. Розподіл за предикторами CIT: вік > 55 років - 385 чол. (40,15\%); IMT > 26 - 744 чол. (77,58\%); шкала ASA (III-IV) - 211 чол. (22,00\%); шкала Mallampati (III-IV клас) - 278 чол. (28,99\%); ТМД - 228 чол. $(23,77 \%)$; за СМД - 266 чол. $(27,74 \%)$. Всього СІТ - $214(22,31 \%)$, 
3 них 42 випадки $(19,63 \%)$ непрогнозовані. Інтубація трахеї при збереженій свідомості використана двічі $(0,93 \%)$, в решті випадків - повторна інтубація трахеї з використанням різних клинків ларингоскопа, BURP-маневр. В 21 випадку $(2,19 \%$ від загальної кількості інтубацій трахеї) ці заходи були неефективними (жінки: 15 - 71,43\%, чоловіки: 6 $28,57 \%)$. Єдиним виходом при цьому була ФБС, під час якої фібробронхоскоп використовувався в якості провідника для інтубаційної трубки.

\section{ВИСНОВКИ}

1. Прогнозована кількість СІТ виявилась вищою від фактичної, в 19,63\% випадків СІТ була непрогнозованою.

2. В 193 з 214 випадків $(90,19 \%)$ проблема СІТ була вирішено за допомогою допоміжних технологій, в 21 $(9,81 \%)$ - ФБС була єдиним ефективним засобом.

3. Питома вага використання ФБС при CIT у групі чоловіків становила $2,53 \%$, у групі жінок - 2,08\%, шо підтвердило гендерний предиктор CIT (Langeron, 2000).

\section{СПИСОК ЛІТЕРАТУРИ}

1. Трудная интубачия трахеи: совреиенные методы решения Е.Н.Клигуненко, О.В.Лященко В.В.Ехалов [и др.] // Медичина Е.Н.Клигуненко, О.В.ЛЯщенко, В.В.Ехалов [и др.]
неотложных состояний. - 2017. - №5 (84). - С. 61-64.

2. Матолінещь Н.В. Досвід проведення відеоларингоскопії при інтубації трахеї за екстреними показаннями в практиці лікаряанестезіолога / Н.В. Матолінеиь, Ю.О. Яськів, М.В. Шпитко // Раіп, Anaesthesia \& Intensive Care. - 2017. - №2 (79). - C. 57-62.

\section{Седінкін В.А., Клигуненко О.М.}

\section{ВПЛИВ КОНЦЕНТРАТУ ПРОТРОМБІНОВОГО КОМПЛЕКСУ НА ПОКАЗНИКИ ГОМЕОСТАЗУ ПРИ ГОСТРІЙ АКУШЕРСЬКІЙ КРОВОВТРАТІ}

\section{ДЗ “Дніпропетровська медична академія МОЗ України”, кафедра анестезіології, інтенсивної} терапії та МНС ФПО, м. Дніпро

\section{АКТУАЛЬНІСТЬ ПРОБЛЕМИ}

Масивна крововтрата в акушерстві часто є причиною розвитку дилюційної коагулопатії та неконтрольованої коагулопатичної кровотечі. Зазначені ускладнення в перипартальному періоді $є$ однією з основних причин розвитку синдрому поліорганної недостатності $(\mathrm{CПOH})$ та призводять до значного підвищення тривалості госпіталізації у відділенні інтенсивної терапії [1]. В даний час багато клініцистів розглядають концентрат протромбінового комплексу (КПК) як серйозну альтернативу застосуванню СЗП при коагулопатіях, обумовлених печінковою недостатністю, та кровотечах різної етіології $[2,3]$.

\section{META РОБОТИ}

Оцінити стан гемодинаміки, водних секторів, гемостазу, частоту і тяжкість клінічних проявів СПОН при застосуванні КПК в лікуванні гострої акушерської крововтрати.

\section{МАТЕРІАЛИ ТА МЕТОДИ}

Після схвалення дизайну дослідження етичним комітетом обстежено 248 жінок (2006-2017 рр.), у яких пологи або ранній післяпологовий період ускладнився гострою важкою крововтратою 3 дефіцитом ОЦК 40-60\%. Залежно від особливостей інтенсивної терапії (IT) пацієнтки були розділені на 2 групи. В 1 групі $(\mathrm{n}=150)$ проводилась стандартна IT гострої крововтрати, згідно клінічним протоколам МО3 України (№782 від 29.12.2005 р. та №205 від 24.03 .2014 р.). В 2 групі $(\mathrm{n}=98)$ в лікування був доданий КПК (Октаплекс, 1000-1500 МО). Групи були порівнянні за демографічними показниками, терміном розродження, објємом крововтрати. Оцінювали: кількість еритроцитів, гемоглобін, гематокрит, ПІ, АЧТЧ, фібриноген; водні сектори організму (загальний об'єм рідини, објєм позаклітинної, внутрішньоклітинної та інтерстиціальної рідини) неінвазивно - інтегральним імпедансним методом; клінічні признаки СПОН. Точки контролю: 12 годин, 1,3 , $5,7,10,14$ і 28 доба після пологів. Оцінка вірогідності проводилась за t-критерієм Стјюдента.

\section{РЕЗУЛЬТАТИ}

При використанні КПК відзначено зменшення на 24,5\% $(\mathrm{p}<0,01)$ загального објєму інфузійно-трансфузійних середовищ; зменшення на $22 \%(\mathrm{p}<0,01)$ објєму введеної плазми та на $9,1 \%(\mathrm{p}<0,05)$ објєму еритроцитів. Також спостерігалося зниження частоти (в 5,1 разів, $\mathbf{p}<0,01)$ i тривалості вазопресорної підтримки (на 1,5 доби, $\mathrm{p}<0,01$ ), ШВЛ (в 5,7 разів, р<0,01), скорочувалася як кількість пацієнток, які потребували замісної ниркової терапії (в 2,9 разів, $<<0,01$ ), так і тривалість останньої (на 1,7 доби, $\mathrm{p}<0,01)$. Більш ніж в 2 рази скорочувалася частота проявів гастроінтестинальної недостатності. Рівні ПІ та фібриногену відповідали нормі к кінцю 1 доби лікування.

\section{вИСНОВКИ}

1. Застосування КПК в програмі IT гострої крововтрати формує рестриктивний тип поповнення дефіциту ОЦК, що забезпечує достовірне зниження частоти клінічних проявів $\mathrm{CПОН.}$

2. КПК запобігає розвитку та прогресуванню коагулопатії при лікуванні гострої акушерської крововтрати.

\section{СПИСОК ЛІТЕРАТУРИ}

1. Sohn C.H. Disseminated Intravascular Coagulation in Emergency Department Patients With Primary Postpartum Hemorrhage / C.H. Sohn, Y.J. Kim // Shock. - 2017 - Vol. 48 (3). - P. 329-332.

2. Collis R.E. Haemostatic management of obstetric haemorrhage R.E.Collis, P.W.Collins // Anaesthesia. - 2015. - Vol. 70. - P. 78-86.

3. Peyvandi F. Future of coagulation factor replacement therapy Haemostasis. - 2013. - Vol. 11(Suppl. 1). - - P. 84-98

\section{Середенко Н.П. \\ ЗМІНИ ПОКАЗНИКІВ ЦЕНТРАЛЬНОЇ ГЕМОДИНАМІКИ ПОРОДІЛЛІ ПРИ ОПЕРАТИВНОМУ РОЗРОДЖЕННІ}

Коливання показників центральної гемодинаміки (ЦГ) під час кесаревого розтину (КР) свідчать про недостатній рівень анестезіологічного захисту, можуть привести до зниження резервів системи кровообігу жінки та негативно вплинути на стан дитини $[1,2]$.

Мета роботи: оцінка стану та зміни основних показників ЦГ в умовах різних методів анестезіологічного забезпечення операції КР.

\footnotetext{
Седінкін В.А., Клигуненко О.М., 2018

Середенко Н.П., 2018
}

\section{МАТЕРІАЛИ І МЕТОДИ}

90 вагітних, які надійшли до розродження до КЗО3 «Харківський міський клінічний будинок №6» розподілені на 3 групи. Група I $(\mathrm{n}=30)$ КР проводився в умовах загальної анестезії (ЗА) з використанням кетаміна, група II $(\mathrm{n}=30)$ - в умовах 3А 3 тіопенталом натрія, група III $(\mathrm{n}=30)$ - в умовах спінальної анестезії (CA) з інтратекальним введеням $0,5 \%$ розчину бупівакаїну. Вивча- 
лись: артеріальний тиск (АТ), частота серцевих скорочень (ЧСС), серцевий індекс (CI), ударний об'єм (УО), хвилинний об'єм кровообігу, загальний периферичний судинний опір (ЗПСС). Оцінка проводилась на 5 етапах: 1 - вихідний; 2 - на початку операції; 3 - через 5 хвилин після народження дитини; 4 - закінчення операції; 5 післяопераційний період.

\section{РЕЗУЛЬТАТИ}

На початку операції у пацієнток усіх груп переважно спостерігався еукінетичний тип гемодинаміки (ГД). У породілль I та II груп перебіг анестезії характеризувався гіперкінетичним типом ГД, відмічалось збільшення ЗПСС (24\%) після інтубації трахеї на 3 етапі з подальшим зниженням показників до вихідного рівня. На даному етапі в умовах ЗА відзначалося зниження УО $(20,4 \%)$ та збільшення ЧСС $(36,2 \%)$. Коливання показників були більш стабільніші у пацієнток II групи. У жінок III групи на 3 етапі відзначалося достовірне збільшення УО (11\%) та зниження ЧСС $(12,7 \%)$. Ці зміни спостерігалися на всіх етапах дослідження. СІ в усіх групах змінювався статистично незначно. На 3 етапі в умовах 3А показники АТ були достовірно вищими. Перебіг післяопераційного періоду у пацієнток усіх груп характеризувався еукінетичним типом ГД

\section{ВИСНОВКИ}

Спінальна анестезія є оптимальним методом при оперативному розродженні шляхом операції КР та забезпечує більш стабільні показники ЦГ, особливо на етапі народження дитини.

\section{СПИСОК ЛІТЕРАТУРИ}

1. Epiu I et al. Key bottlenecks to the provision of safe obstetric anaesthesia in low- income countries, BMC Pregnancy Childbirth, 2017

2. Lavie A et al. Maternal cardiovascular hemodynamics in normotensive versus preeclamptic pregnancies: a prospective longitudinal study using a noninvasive cardiac system, BMC Pregnancy Childbirth, 2018.

\section{Сидюк О.Є., Мазур А.П., Сидюк А.В., Клімас А.С., Савенко Г.Ю.} ПІСЛЯОПЕРАЦІЙНЕ ЗНЕБОЛЕННЯ У ПАЦІЄНТІВ 3 ЕЗОФАГЕКТОМІЄЮ

ДУ «Національний інститут хірургії та трансплантології ім.О.О.Шалімова НАМН України», м. Київ, Україна

\section{АКТУАЛЬНІСТЬ ПРОБЛЕМИ}

Торако-абдомінальний доступ - одна з найбільш болючих хірургічних маніпуляцій, яка асоціюється 3 значною післяопераційною дисфункцією діафрагми і респіраторними порушеннями [1]. Рутинні методи знеболювання не завжди забезпечують адекватну аналгезію. Торакальний паравертебральний блок (ПВБ) може бути альтернативою для пацієнтів після торакотомії, у яких бажано вживати лише односторонній сенсорний блок [2].

Мета роботи: покращити результати анестезіологічного забезпечення при хірургічному лікуванні хворих зі злоякісними захворюваннями стравоходу шляхом розробки i застосування методу раціонального післяопераційного знеболення.

\section{МАТЕРІАЛИ ТА МЕТОДИ}

У дослідження включені 80 хворих, оперованих комбінованим торако-абдомінальним доступом 3 приводу злоякісних пухлин стравоходу: група порівняння - 40 пацієнтів, у яких використана післяопераційна торакальна епідуральна анестезія (установка перед операцією 2 катетерів в епідуральний простір: 1 - на рівні Th2-Th4, 2-й - на рівні Th5-Th7) і група дослідження - 40 пацієнтів, у яких використана комбінована післяопераційна аналгезія (торакальна епідуральна анестезія (ТЕА) і ПВБ) один катетер встановлювався перед операцією в епідуральний простір на рівні Th5-Th7, другий - інтраопераційно в паравертебральний простір на рівні виконання торакотомії.
Для з'ясування факторів, пов'язаних з ризиком розвитку ускладнень була побудована багатофакторна логістична модель регресії.

\section{РЕЗУЛЬТАТИ}

Зростання ризику розвитку ускладнень пов'язане з віком пацієнта, ВШ (відношення шансів) = 1,18 на кожен рік. Виявлено також зростання ризику розвитку ускладнень 3 ростом ступеня дисфагії, ВШ $=2,8$, в середньому, на кожну ступінь. Доведено, що при застосуванні анестезіологічного забезпечення післяопераційного знеболення з використанням ПВБ + ТЕА лікування було ефективним для всіх хворих, ризик неефективності лікування склав $0 \%$, при використанні ж тільки ТЕА ризик неефективності лікування $-42,5 \%$ $(\mathrm{p}<0,001)$.

\section{ВИСНОВКИ}

Визначено, що найбільш перспективним методом знеболення у хворих після торако-абдомінальних оперативних втручань $€$ торакальний паравертебральний блок, який в комбінації 3 іншими методами післяопераційного знеболення дозволяє забезпечити максимальний рівень захисту від хірургічної агресії при мінімальному рівні ускладнень, пов'язаних 3 методикою знеболення.

\section{СПИСОК ЛІТЕРАТУРИ}

Kobayashi $R$, Mori $S$ et al. Paravertebral block via the surgical field versus epidural block for patients undergoing thoracotomy: a randomized

2. Manoj K. Karmakar Thoracic Paravertebral Block. Anesthesiology 9 2001, Vol.95, 771-780.

\section{Старіков А. В., Левченко Т.М. ОСОБЛИВОСТІ ЛІКУВАННЯ БОЛЮ У ХВОРИХ ПРИ ОНКОЛОГІЧНІЙ ПАТОЛОГІї}

Больовий синдром, що супроводжує гематоонкологічну патологію, на сьогоднішній день залишається недостатньо вивченою проблемою. Розкриття патогенетичних механізмів походження больового синдрому у хворих 3 онкологічною патологією дає можливість удосконалити показання, щодо призначення відповідних знеболюючих засобів.

Нами проаналізовані літературні дані і власний клінічний досвід проведення фармакологічної корекції болю у хворих, яким проводили курси цитостатичної інтенсивної хіміотерапії в умовах відділення інтенсивної терапії.

Больовий синдром досить часто розвивається у хворих, які отримували відповідні протоколи лікування, шо включали цитотоксичні препарати. Таке лікування може призводити до розвитку поліорганних порушень i периферичної нейропатії.

Препарати для аналгезії можуть бути складовою частиною антинеопластичної хіміотерапії та паліативної

\footnotetext{
- Сидюк О.Є., Мазур А.П., Сидюк А.В., Клімас А.С., Савенко Г.Ю., 2018

- Старіков А. В., Левченко Т.М., 2018
} 
радіотерапії. Але при призначенні препаратів для аналгезії онкологічним хворим, треба приймати до уваги вплив цих препаратів на рівень нейтропенії та тромбоцитопенії.

Нестероїдні протизапальні препарати слід призначати 3 обережністю у хворих 3 порушеннями ниркового кровообігу та у пацієнтів із ризиком кровотечі внаслідок тромбоцитопенії чи інших коагуляційних порушень.

В залежності від інтенсивності больового синдрому застосовуються препарати як слабкої так і сильної дії. Так, хворим із слабким болем. призначають так препарати як парацетамол. При помірному больовому синдромі необхідно застосовувати кодеїн, оксикодон, бупренорфін і трамадол. Сильні опіоїди, такі як морфін, метадон і фентаніл, слід призначати при вираженому больовому синдромі. Метадон також показаний у хворих 3 нейтропенічним болем та у тих випадках, коли застосування інших опіоїдів призвело до розвитку ускладнень.

Створення програми комбінованого застосування аналгетичних засобів у онкологічних хворих дає можливість зменшити побічні дії опіоідних препаратів завдяки зниженню доз препаратів і створенню опіоідзберігаючих комбінацій опіатів та НПЗП, або НПЗП і місцевих анестетиків. Це дає можливість, використовувати меншу дозу кожного препарату та підвищувати антиноцицептивний потенціал, що в свою чергу дозволяе зменшити частоту розвитку побічних ефектів, характерних для опіатів.

Таким чином, впровадження відповідного алгоритму лікування болю у хворих 3 онкологічною патологією, буде сприяти покращенню якості життя при проведенні курсів інтенсивної цитостатичної терапії на різних стадіях захворювання.

\section{СПИСОК ЛІТЕРАТУРИ}

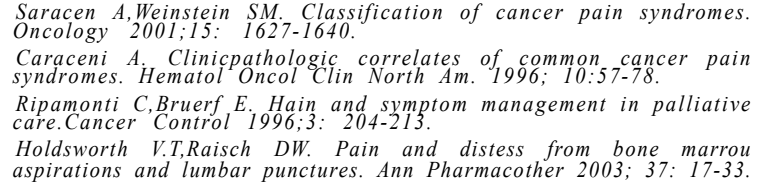

\title{
Старіков А.В., Хитрий Г.П., Левченко Т.М., Афранасьєв С.Є.
} ІНФУЗІЙНА ДЕТОКСИКАЦІЙНА ТЕРАПІЯ У ХВОРИХ 3 ЕНДОТОКСИКОЗОМ

Характер та напрямок інтенсивної терапії при інтоксикаційному синдромі в першу чергу залежить від етіопатогенетичних особливостей захворювання та наявності коагуляційних порушень. Тому питання застосування інфузійних детоксикаційних розчинів залишається актуальним.

\section{МАТЕРІАЛИ ТА МЕТОДИ ДОСЛІДЖЕННЯ}

Ефективність лікування була проаналізована у 22 хворих із клініко-лабораторними проявами ендотоксикозу, які були госпіталізовані у відділення реанімації для проведення інтенсивної терапії з приводу панкреатиту, гематологічної патології (гемолітичний криз), печінково-ниркової недостатності різного генезу. У хворих спостерігалась прихована гіповолемія, згущення крові, коагуляційні порушення. Для ïx корекції в комплексному лікуванні було запропоноване введення розчину латрену. Доза препарату становила 400 мл внутрішньовенно краплинно впродовж 120 хвилин.

\section{РЕЗУЛЬТАТИ ТА ЇХ ОБГОВОРЕННЯ}

Моніторинг гемодинамічних показників показав, що після введення розчину латрену, порівняно 3 початковими показниками, вдалося досягти зростання УО серця на $5,8 \%$, CВ - на $10 \%$. Це супроводжувалось зниженням ЗПСО в середньому на $13 \%(\mathrm{P}<0,05)$, що було обумовлено зниженням судинного тонусу за рахунок блокування симпатичної інервації та наявністю прихованої гіповолемії різного ступеня вираженості.

Як свідчать отримані результати, застосування латрену в об'ємі 400 мл не сприяло суттєвому зростанню серцевого та ударного викиду, але супроводжувалось достовірним зниженням ЗПСО, що сприяло покращенню капілярного кровообігу, клубочкової фільтрації і зростанню діурезу в середньому на $15 \%$.

Після застосування розчину мало місце подовження показника ПЧ та зниження агрегаційної здатності тромбоцитів до АДФ, що сприяло покращенню реологічних та агрегаційних властивостей крові. Це, на нашу думку, було обумовлене дією пентоксифілину, який є складовою частиною препарату. Крім цього, виявлено достовірне скорочення часу розчинення фібринового згустку в тесті ХЗФ, що обумовлено активацією плазмінової системи під впливом препарату. Після введення 400 мл розчину мало місце зниження кількості фібриногену, що може пояснюватись тимчасовою гемодилюцією.

\section{ВИСНОВКИ}

Таким чином, патогенетично обгрунтована інфузійна терапія, складовою частиною якої може бути латрен, сприяє корекції можливих мікроциркуляційних, реологічних та коагуляційних розладів у пацієнтів з інтоксикацією різного генезу.

\section{СПИСОК ЛІТЕРАТУРИ}

1. Буланов А.Ю. Влияние различных типов колоидных объемозамещающих растворов на изиенение системы гемостаза / А. Ю Буланов, В.М.Городечкий //Анесте зиология и реаниматология. - 2004. - №2. - С.25-30.

2. Старіков А.В. Клініка, діагностика та інтенсивна терапія невідкладних станів при гематологічній патології / А.В. Стариков, Л.В.Баронська, О.І.Гаврилюк // Журнал практичного лікаря. - 2009. - № 5-6. - С.27-31.

3. Старіков А.В. Фармакокінетика і фармакодинаміка медикаментозних заходів, що використовують в інтенсивній терапії пацієнтів із гемокоагуляиійними порушеннями / А.Старіков // Кровообіг та гемостаз. - 2009. - №1-2. - С. 72-76.

\section{СтУпницький М.A. ${ }^{1}$, Білецький О.B. ${ }^{2}$ \\ ПРОГНОЗУВАННЯ ВИЖИВАННЯ У ПАЦІЄНТІВ 3 ПОЄДНАНОЮ ТОРАКАЛЬНОЮ ТРАВМОЮ}

УДК: 616.712-001-036.17-037

\author{
Військово-медичний клінічний центр Західного регіону ${ }^{1}$ \\ Харківська міська клінічна лікарня швидкої та невідкладної медичної допомоги \\ імені профр. О.І.Мещанінова. ${ }^{2}$
}

\section{вступ}

Значна частина смертельних випадків від важких травматичних пошкоджень відбувається після стабілізації стану хворого у стаціонарі. У сучасній інтенсивній терапії відсутня загальноприйнята програма лікувальної тактики у разі поєднаної травми грудної клітки (ПТТ) в залежності від тяжкості стану пацієнтів, кількості уражених систем і специфіки органної дисфункції. Не

\footnotetext{
Старіков А.В., Хитрий Г.П., Левченко Т.М., Афанасьєв С.С. , 2018

Ступницький М.А., Білечький О.В., 2018
} 
розроблені методи кількісної оцінки прогнозу, тяжкості стану, які необхідні для вибору хірургічної тактики, об'єму інтенсивної терапії, клінічного моніторингу та оцінки ефективності лікування, що обумовлено прийнятою в світі концепцією лікування постраждалих 3 політравмою «Damage control». Неважаючи на успіхи у лікуванні множинних та поєднаних травм, за останні десятиліття зростає кількість ускладнень у віддалені періоди після травми, причому значно частіше почали розвиватись множинні та тяжкі ускладнення.

Мета роботи: розробити модель прогнозування виживання пацієнтів 3 тяжкою поєднаною торакальною травмою у ранньому посттравматичному періоді.

\section{МАТЕРІАЛИ ТА МЕТОДИ}

Обстежено 73 пацієнти чоловічої статі віком від 20 до 68 років 3 тяжкою ПТТ, що лікувались у Харківській міській клінічній лікарні швидкої та невідкладної медичної допомоги імені проф. О.І.Мещанінова. Критеріями для включення слугували: дорослий вік (>18 p), наявність закритої травми грудної клітки 3 внутрішньогрудними об‘ємами, забоєм легень, серця, множинними (>3) переломами ребер, що поєднувались 3 пошкодженнями інших частин тіла.

Дослідження виконували у 3 етапи: 1-й - 1-2-а доба; 2-й 3-4-а доба та 3-й - 5-6-а доба. Пацієнти були розподілені на 2 групи: 1-a - пацієнти, котрі видужали $(\mathrm{N}=42)$ та 2-га пацієнти 3 летальним результатом $(\mathrm{N}=31)$. Для побудови математичної моделі застосовували метод побудови бінарної логістичної регресї̈ шляхом покрокового включення змінних. Як залежну бінарну змінну обрано результат лікування (видужання або загибель).

\section{РЕЗУЛЬТАТИ ДОСЛІДЖЕННЯ}

За результатами регресійної моделі прогнозування летальності у пацієнтів 3 тяжкою поєднаною торакальною травмою на 1-2-у добу посттравматичного періоду отримано рівняння, що дає можливість прогнозувати летальність пацієнтів з критерієм згоди хі-квадрат=0,0202 3 3 ступенями свободи та значенням $\mathrm{p}=0,999238$, на 3-4-ту добу критерієм згоди хі-квадрат становив 0,000089 31 ступенем свободи та значенням $\mathrm{p}=0,992441$, а на 5-6-ту добу отримано рівняння покрокової логістичної регресії 3 показником хі-квадрат $=0,00433$ ступенями свободи та $\mathrm{p}=0,99993$. Відсоток відхилень пояснених моделлю на 1-2-гу добу склав 83,3\%, на 3-4-ту - 85,5\%, а на 5-6-ту - 87,8\%.

\section{ВИСНОВКИ}

На основі розрахованих моделей категоріальних логістичних регресій можна достовірно оцінити прогноз у пацієнтів 3 ПТТ у ранньому поттравматичному періоді. Прогностична цінність показників гомеостазу у відношенні до фатальних результатів травматичної хвороби тяжкої ПТТ різна в залежності від доби посттравматичного періоду. Крім того, одні і ті ж самі показники не можуть використовуватись для оцінки стану пацієнтів на різних етапах посттравматичного періоду.

\title{
Тітов І.І., Волошинський О.В., Майданська І.С., Нестор І.І., Венгрович В.В. СУЧАСНІ МОЖЛИВОСТІ ІНТЕНСИВНОÏ ТЕРАПІЇ ХВОРИХ 3 ДЕКОМПЕНСОВАНИМ ПЕРЕБІГОМ ХОЗЛ
}

\author{
Івано-фрранківський національний медичний університет
}

Хронічне обструктивне захворювання легень (ХОЗЛ), в основі якого лежить звуження бронхів за рахунок запалення та втрата еластичного каркасу легень за рахунок емфіземи, займає одне з провідних місць серед причин смерті у світі i, як очікується, до 2020 року сягне позначки 6 млн. хворих на рік. Загострення ХОЗЛ є головною причиною смерті, а їх передумовою є інфекції трахео-бронхіального дерева (50$60 \%$ бактерії та до $30 \%$ вірусів), неконтрольована оксигенотерапія, серцева недостатність, аритмії, ТЕЛА, метаболічні порушення, аспірація, вживання діуретиків, седативних тощо [1].

Останні роки завдяки ефективній базовій терапії ХОЗЛ, тривалість життя цієї категорії хворих зросла, проте перебіг декомпенсації став тяжчим.

При прийомі у ВІТ хворого $з$ декомпенсованим ХОЗЛ важливим є динамічне дослідження газового складу артеріальної крові $\left(\mathrm{PaO}_{2}, \mathrm{PaCO}_{2}, \mathrm{pH}, \mathrm{SaO}_{2}\right)$ та спірографія (об'єм форсованого видиху в 1 с секунду, ОФВ ). Призначення/продовження адекватної базової інгаляційної терапії (симбікорт 320 двічі на добу + тіотропій/олодатерол) ХОЗЛ $\epsilon$ ключовою позицією лікування, в доповнення до якої призначають антибіотики (макроліди, $\beta$-лактами, респіраторні фторхінолони, цефалоспорини II та III, доксациклін), ГКС перорально (40-80 мг/добу медролу), низькомолекулярні гепарини, при цьому активна інфузійна терапія не показана. Контроль легеневої гіпертензії здійснюємо силденефілом (100 мг/добу перорально) або/та ілопростом (інгаляційно). Методом покращення бронхіальної провідності, яким ми часто користуємося, є вібро-перкусійний масаж (система Vest, США), який ми призначаємо в постуральному положенні перед санаційною ФБС та впродовж доби. Контрольована оксигенотерапія здійснюється безперервно (iї мета: $\mathrm{PaO}_{2}>60$ мм рт.ст. і $\mathrm{SpO}_{2}>90$ $92 \%)$ за допомогою масок Вентурі, при можливості застосовується Геліокс. При вираженій задишці в спокої 3 тахіпноє $>25-30 /$ хв., $\mathrm{PaO}_{2} / \mathrm{FiO}_{2}<200$ мм рт.ст., $\mathrm{pH}<7,35$ і $\mathrm{PaCO}_{2}>45$ мм рт.ст. ми завжди розпочинаємо НІВЛ 3 підбором доз $\mathrm{O}$ та РЕЕР під контролем капнографії та $\mathrm{pH}$ артеріальної крові. Інвазивну вентиляцію розпочинаємо при неефективності НІВЛ та зниженні артеріального $\mathrm{pH}<7,2$ з регуляцією по тиску згідно стратегії контрольованої гіповентиляції. При цьому уникаємо «нормального» $\mathrm{PaO}_{2}$, $\mathrm{SpO}_{2}$ i особливо $\mathrm{PaCO}_{2}$ (небезпечно не підвищене $\mathrm{PaCO}_{2}$, a респіраторний ацидоз), а адаптацію хворих до респіратора здійснюємо пропофолом, дексмедетомідином чи севофлураном за допомогою системи ANACONDA. Сучасним i перспективним методом екстракорпоральної корекції критичної гіперкапнії та гіпоксемії у хворих з ХОЗЛ $\epsilon$ «легеневий діаліз» (системи Hemolung CR4, Novalung, Cardiohelp). Система Novalung застосована нами двічі.

\section{СПИСОК ЛІТЕРАТУРИ}

Мостовой Ю.М. Хронічне обструктивне захворювання легень. Ключові питання (Академія дистанційного навчання) //Укр. мед. часопис.-2016.-№ 4.-С. 63-66.

\section{Тітов І.І., Волошинський О.В., Мартин А.Ю., Вінтоняк І.В., Нестор І.І. ОЦІНКА ЕФЕКТИВНОСТІ НЕЙРОПРОТЕКТОРНОЇ ТЕРАПІЇ ПРИ ЧМТ}

\section{Івано-франківський національний медичний університет}

Черепно-мозкова травма (ЧМТ) - $є$ найбільш частим і тяжким видом травматизму. Травми черепа та головного мозку складають $30-40 \%$ усіх травм і посідають перше місце за показниками летальності та інвалідизації серед осіб працездатного віку. За даними ВОО3 щорічно у світі отримують ЧМТ понад 10 млн. осіб, а 250-300 тис. із цих 
випадків завершуються летально. В Україні частота ЧМТ щорічно становить, в середньому, 4-4,2 на 1000 населення а помирає 2,4 на 10 тис. населення (в США - 1,8-2,2) [1].

\title{
МАТЕРІАЛИ І МЕТОДИ
}

Ми спостерігали 65 потерпілих з ЧМТ та забоєм головного мозку тяжкого ступеня. 3 них було сформовано дві групи, співставні між собою за віком, статтю, тяжкістю вихідного стану. Хворим I групи $(\mathrm{n}=35)$ в комплекс нейрореабілітаці було включено в/в інфузію церебролізину (EWER Pharma Австрія) 30 мл/добу, а хворим II групи $(\mathrm{n}=35)$ церебролізин 30 мл/добу+цитіколін (Ceraxon, Такеда, Японія). Усім хворим підтримували вільну прохідність дихальних шляхів, проводили санаційні ФБС, антибактеріальну терапію, тромбопрофілактику, клінічне харчування [1]. Тривалість курсу лікування і кінцева точка оцінки лікування - 21 доба. Контроль ефективності лікування: загально-клінічні ознаки, BIS-індекс, індекс пригнічення (SR) (BIS Vista, USA), концентрація нейронспецифічної енолази (HCE) (ELISA Kit, Alpha diagnostic, USA).

\section{РЕЗУЛЬТАТИ ТА ЇХ ОБГОВОРЕННЯ}

Вихідні дані BIS-індексу коливалися на рівні 22-47 (глибоке пригнічення функціональної активності головного мозку відповідало глибокій комі). У хворих I групи після завершення курсу лікування BIS-індекс становив 44-79\%, у II групі - 52-88\%. Індекс пригнічення (SR) перед початком

лікування був в діапазоні 73-61\% (виражена десинхронізація в роботі ЦНС, втрата інтегративної функції ЦНС). В кінці лікування у I групі - 35-30\%, а у хворих II групи - 31-14\% (поступове відновлення цілісної біоелектричної активності ураженого мозку та підгрунття для відновлення продуктивної свідомості). Динаміка змін НCE: референтні значення $7,36 \pm 1,74$ нг/мл; вихідні значення - 89,12 $\pm 5,40$ нг/мл, після завершення курсу лікування у I групі $28,62 \pm 1,09$ нг/мл, у II групі - 19,22 1,12 нг/мл. У I групі померло 8 хворих $(12,3 \%)$, а у II групі-5 (7,69\%). Основні причинами смерті ескалація внутрішньогоспітальної поліантибіотикорезистентної інфекції (пневмонії, гнійні ендобронхіти) та гнійний вентрикуліт.

\section{ВИСНОВКИ}

Використання впродовж 21 доби церебролізину 30 мл/добу та цитіколіну 2000 мг/добу з 1 дня після отримання ЧМТ створює передумови до нормалізації показників пошкодження нейронів, відновлює нормальну біоелектричну активність мозку та суттєво зменшує періоди «нейронального пригнічення», сприяє збільшенню об'єму свідомості у потерпілих, є оптимальним тлом для нейрореабілітації та асоціюється $з$ кращими наслідкам лікування.

\section{СПИСОК ЛІТЕРАТУРИ}

1. Бэр М. Нейропротекция: модели, механизмы, терапия: пер. с англ. М.: БИНОМ. Лаборатория знаний, 2011. 429 c.

\section{Timoв I.I., Данилюк T.T., Венгрович В.В., Нестор I.І., Бойко М.А. МІКРОБІОЛОГІЧНЕ ОТОЧЕННЯ БАГАТОПРОФІЛЬНОГО ВІДДІЛЕННЯ IHТЕНСИВНОÏ ТЕРАПIÏ ТА АНТИБІОТИКОРЕЗИСТЕНТНІСТЬ ЗБУДНИКІВ}

\author{
Івано-фрранківський національний медичний університет
}

Багатопрофільні відділення інтенсивної терапії мають найвищий ризик селекції високопатогенної і поліантибіотикорезистентної мікрофлори. Це пов'язано 3 активним переміщенням хворих з різною патологією в межах стаціонару та 3 інших лікарень регіону, широким і не завжди раціональним застосуванням антибіотиків тощо [1].

\section{МАТЕРІАЛИ І МЕТОДИ}

За допомогою комп'ютерної програми WHONET 5.4 було проаналізовано 127 ізолятів з полірезистентністю до 3-х та більше антибіотиків від 98 пацієнтів, які лікувалися 3 приводу вентилятор-асоційованих госпітальних пневмоній. Забір матеріалу з просвіту бронхів - ФБС та «захищені щітки» (Flexible brush 6Fr, Brightfield endoscopes, Німеччина).

\section{РЕЗУЛЬТАТИ}

Домінуючими госпітальними штамами у BIT $\epsilon$ : $P s$. aeruginosa - 24,9\%, Acinetobacter baumanii - 23,2\%, Klebsiella pneumoniae - $26,1 \%$, Escherichia coli $-7,1 \%$ та $S$. aureus - 16,2\%, з яких 76,2\% виявилися MRSA. При порівнянні з попередніми роками встановлено збільшення частоти виділення Klebsiella pneumoniae $(+8,1 \%)$, Acinetobacter baumanii $(+6,3 \%)$ та $S$. aureus $(+4,8 \%)$. Найчастіша мікробна асоціація - Ps. aeruginosa $+K l$. pneumoniae, збудники якої виявляють низьку чутливість до більшості сучасних антибіотиків, включаючи карбапенеми і захищені цефалоспорини. Разом 3 цим, виявлено відновлення чутливості деяких госпітальних штамів мікроорганізмів до «старих» антибіотиків, які практично не використовувалися в клініці останні 10-20 років - канаміцину, гентаміцину, ципрофлоксацину, доксацикліну, фосфоміцину. Санітарно-гігієнічні та дезінфекційні заходи із застосуванням сучасних дезінфектантів здатні лише частково контролювати (зменшувати) ступінь мікробної інвазії. Серед першочергових заходів для стримування антибіотикорезистентності $\epsilon$ регулярне ведення мікробіологічного паспорту відділу, раціональне i коректне призначення дієвих антибіотиків, тимчасове вилучення із клінічного вжитку ряду антибіотиків до відновлення до них чутливості мікрофлори, жорсткі санітарно-гігієнічні та дезінфекційні заходи, особливо в питанні переміщення в межах лікарні та гігієни рук персоналу. Великі надії покладаються також на удосконалення уже існуючих (іміпенем/циластатин/ релебактам, азтреонам/авібактам, цефтазидим/авібактам, меропенем/ваборбактам) та нових антибіотиків.

\section{ВИСНОВКИ}

1. Локальне мікробіологічне оточення у багатопрофільних ВІТ в динаміці погіршується. Основна небезпека - поліантибіотикорезистентність. Раціональне призначення (максимальні разові і добові дози, режим введення, тривалість курсу для повної ерадикації) та ротація антибіотиків дозволяє незначно і тимчасово стримувати прогресування антибіотикорезистентності.

\section{СПИСОК ЛІТЕРАТУРИ}

1. Бондар М.В. Антибіотикорезистентність мікроорганізмів: механізми розвитку и чиляхи запобігання / М.В. Бондар, М.М. Пилипенко, М.Ю. Свінтуковський, Л.А. Харченко, О.М.Пре-

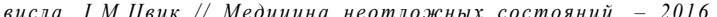
№ 3 - C $11-17$

\footnotetext{
Тітов I.I., Данилюк T.T., Венгрович В.В., Нестор I.I., Бойко М.А., 2018
} 


\section{Тітов І.І., Кіндяк І.Р., Протас В.В., Костирко Р.Б., Нестор І.І., Бахмат Н.М. ДОСВІД ЗАСТОСУВАННЯ ЕСМОЛОЛУ ГІДРОХЛОРИДУ ПРИ ЛІКУВАННІ ГІПЕРТЕНЗИВНИХ РЕАКЦІЙ І ТАХІАРИТМІЙ ПІД ЧАС ЗАГАЛЬНОГО ЗНЕБОЛЕННЯ}

Івано-фрранківський національний медичний університет

При анестезіологічному забезпеченні стоматологічних та ринологічних втручань часто застосовується інтраназальна аплікація та місцева інфільтративна анестезія 3 додаванням $0,1 \%$ адреналіну гідрохлориду, що різко дестабілізує гемодинаміку та може обумовлювати розвиток тахіаритмії.

Мета роботи: клінічна оцінка ефективності та безпечності есмололу гідрохлориду (Біблок, Юрія-Фарм) для ліквідації вазопресорних піків артеріального тиску та/чи тахіаритмії в умовах загальної анестезії.

\section{МАТЕРІАЛИ ТА МЕТОДИ}

Ми спостерігали 50 пацієнтів віком $43 \pm 3,2$ років, серед них 19 жінок і 31 чоловіків, яким виконані однотипні оперативні втручання. Після преоксигенації індукція анестезії: фентаніл 0,025 мг/кг + пропофол 2,5 мг/кг маси тіла та атракурію бесилат 0,6 мг/кг маси тіла. ШВЛ респіратором «Uvent» (Україна). Підтримання анестезії фентаніл+пропофол +атракуріум+декскетопрофен. Контроль гемодинаміки - монітор „Utas-300” (Україна). Отримані дані опрацьовано статистично.

\section{РЕЗУЛЬТАТИ ТА ЇХ ОБГОВОРЕННЯ}

У хворих основної групи після топічного застосування адреналіну підвищення АТ на $17,8 \%$ та ЧСС на $41,2 \%$ від вихідного рівня. Введення есмололу (50 мг) впродовж 90120 сек. призвело до зниження АТ до прийнятного рівня та повного усунення тахікардії. У 11 хворих (44\%) введення есмололу в дозі 30-50 мг одноразово повторювали, а у 3 пацієнтів налагодили автоматичну інфузію (12,5-25 мкг/кг/хв.) впродовж оперативного втручання. Епізодів аритмії у хворих даної групи не зафіксовано.
У хворих контрольної групи після індукції анестезії САТ знизився $(\mathrm{p}<0,05)$ на $12 \%$ від вихідного рівня, а після інтубації трахеї зріс $(\mathrm{p}<0,05)$ на $17,3 \%$ порівняно 3 вихідними значеннями. Застосування адреналіну призвело до подальшого зростання $(\mathrm{p}<0,05)$ CAT, який вже на $24,9 \%$ перевищував вихідний рівень. Значення ЧСС у хворих контрольної групи зростали $(\mathrm{p}<0,05)$ як після інтубації трахеї - на 29,7\%, так і після використання адреналіну - на $36,5 \%$ порівняно 3 етапом індукції анестезії. При цьому контроль гіпертензії та тахікардії успішно забезпечували поглибленням загальної анестезії, після чого значення BIS-індексу коливалися в діапазоні 18-28, що потенційно небезпечно, оскільки може спричинити транзиторну когнітивну дисфункції в післяопераційному періоді. В даній групі мали місце 6 випадків тахіаритмії, 2 з яких потребували лікування.

\section{ВИСНОВКИ}

1. Есмололу гідрохлорид (Біблок) в схемі загальної анестезії, потенціює гіпотензивний ефект пропофолу і дозволяє ефективно ліквідувати небажані вазопресорні реакції у відповідь на ларингоскопію, інтубацію трахеї і гіпертензивний вплив адреналіну.

2. Есмолол може бути безпечно і пріоритетно використаний у складі медикації загальної анестезії. Недостатності клінічного ефекту, ускладнень та побічних ефектів чи алергій, при застосуванні есмололу під час загального знеболення не спостерігали.

\section{СПИСОК ЛІТЕРАТУРИ}

1. Guidelines for perioperative risk assessment and preoperative cardiac management in non-cardiac surgery // European Heart Journal. $-2009 .-30 .-2769-2812$

УДК 618-08

\section{Тітов І.І., Мартин А.Ю., Вінтоняк І.В., Грищенко С., Венгрович В.В. СУЧАСНИЙ ПОГЛИБЛЕНИЙ ВОЛЮМЕТРИЧНИЙ МОНІТОРИНГ ГЕМОДИНАМІКИ}

Івано-франківський національний медичний університет

Стандартний моніторинг у ВIT не дозволяє переконливо діагностувати гіповолемію, серцеву недостатність, системну вазодилятацію [1]. Існує багато методик оцінки вищеназваних станів (сонографічний доплер, біоімпеданс, частково-реверсивне дихання, аналіз форми пульсової хвилі, методика Сван-Ганца), проте кожна 3 них не ідеальна, а деякі незручні для тривалого моніторування в умовах BIT.

Нова технологія РІCCO базується на транспульмональному розведенні індикатора та аналізі пульсової хвилі, дозволяє безперервне та періодичне вимірювання СВ, перед- та післянавантаження, скоротливості серця, внутрішньогрудний об'єм крові та позасудинної води легень і при цьому мінімально інвазивна. Найчастіше моніторування за технологією PICCO використовується при лікуванні септичного та кардіогенного шоку, опіковій травмі, політравмі, ГРДС, при обширних хірургічних втручаннях, в кардіохірургії, нейрохірургії тощо
Особливо цінними є параметри переднавантаження, коли отримуємо інформацію про об'єм крові $\left(\mathrm{ml} / \mathrm{m}^{2}\right)$ замість тиску наповнення, можемо оцінювати відповідь на волемічне навантаження (чи призведе збільшення переднавантаження до підвишення CB?) за показниками варіації ударного об'єму та пульсового тиску. Унікальною $\epsilon$ інформація про EVLW (позасудинну воду в легенях: внутрішньоклітинну, інтерстиціальну, інтраальвеолярну) та PVPI (індекс проникливості судин легень), які віддзеркалюють в динаміці ступінь вираженості набряку легень.

Розпочата нами робота 3 поглибленого моніторування хворих за технологією РІССО стосується, передусім, потерпілих і хворих з гострими церебральними катастрофами. В своїй роботі ми використовуємо модель «РICCO » (Pulsion, Німеччина) з модулями CeVOX та LiMON, що дає додаткові можливості проводити центральну венозну оксиметрію $(\mathrm{ScvO}, \%)$, яка віддзеркалює загальний баланс між доставкою $\left(\mathrm{DO}_{2}\right)$ та

\footnotetext{
Тітов I.I., Кіндяк I.P., Протас В.В., Костирко Р.Б., Нестор I.I., Бахмат Н.М., 2018

Тітов I.І., Мартин А.Ю., Вінтоняк І.В., Грищенко С., Венгрович В.В., 2018
} 
споживанням ( $\mathrm{VO}_{2}$ ) кисню в організмі, а його зниження свідчить про небезпечне порушення оксигенації тканин а також перфузію внутрішніх органів, передусім печінки. Отримувана інформація аналізується за графічним алгоритмом «Дерево прийняття рішень» i, по-суті, зводиться до призначення/зміни дози чи відміни інфузії, вазопресорів, інотропних середників та діуретиків Вигоди від поглибленого моніторингу давно відомі очевидні: лише врахування показника позасудинного об'єму води при проведенні інтенсивної терапії, за даними Mitchel JP та співавт. (1992) скорочують на 59\% час перебування хворих на ШВЛ $\mathrm{i}$ на 53\% тривалість перебування у BIT.

\section{вИсновки}

1. Технологія PICCO є максимально комфортною для потреб інтенсивної терапії, малоінвазивною, високоінформативною та безпечною.

2. Проведення IT «з відкритими очима» завдяки технології РІCCO покращує результати лікування, несе фармако-економічні вигоди.

\section{СПИСОК ЛІТЕРАТУРИ}

1. Mitchel JP, Schuller D, Calandrino FS, Schuster DP. Improved outcome based on fluid management in critically ill patients reguiring pulmonary artery catheterization. American Rev Respir Dis 1992; 145 (5): $990-8$.

\title{
Федоров Ю.П, Пращерук П.В, Пугачев В.А, Меренков В.Г., Ковшарь Н.П. АНЕСТЕЗИОЛОГИЧЕСКОЕ СОПРОВОЖДЕНИЕ ПРИ «ГИБРИДНЫХ» ОПЕРАЦИЯХ НА СОСУДАХ НИЖНИХ КОНЕЧНОСТЕЙ
}

\author{
Харьковская клиническая больница на железнодорожном транспорте №1, отделение \\ анестезиологии с койками для интенсивной терапии \\ Харьковская клиническая больница на железнодорожном транспорте №2, отделение \\ анестезиологии с койками для интенсивной терапии
}

\section{ВВЕДЕНИЕ}

Использование технологий эндоваскулярной хирургии в сочетании с классическими методами реконструктивных операций на нижних конечностях последовательно в два этапа, позволяет восстановить кровоток при многоуровневых поражениях артериального русла, позволяя спасти конечности от ампутации. При этом частота «гибридных» операций неуклонно растет, достигая 10\% в нашей клинике.

\section{ЦЕЛЬ РАБОТЫ}

Определение эффективности и оптимальности метода продленной эпидуральной анестезии при «гибридных» оперативных вмешательствах в случае многоуровневого атеросклеротического поражения артериального русла.

\section{МАТЕРИАЛЫ И МЕТОДЫ}

Операции по восстановлению артериального кровотока на протяженном участке подвздошно - бедренно подколенного сегмента выполняются последовательно в два этапа: сначала проводится открытое бедренноподколенное шунтирование в операционной, затем пациент переводится в рентгеноперационную, где другая бригада проводит баллонную ангиопластику и/или стентирование подвздошного сегмента артериального русла. В качестве анестезиологического пособия используется продленная эпидуральная анестезия, которая позволяет работать хирургам в течение длительного промежутка времени. При этом как пациенту, так и обеим хирургическим бригадам создаются комфортные условия: хорошее обезболивание при сохраненном самостоятельном дыхании, достаточный запас времени для полной хирургической коррекции.

\section{РЕЗУЛЬТАТЫ}

Продленная эпидуральная анестезия обеспечивает полноценный обезболивающий эффект на протяжении длительного времени выполнения двухэтапного хирургического вмешательства при многоуровневом поражении артериального русла.

\section{выводы}

Продленная эпидуральная анестезия является методом выбора при длительных «гибридных» хирургических реконструкциях артериальных сосудов таза и нижних конечностей.

\section{Федоров Ю.П, Пугачев В.А, Пращерук П.В, Антошкин Р.В., Ковшарь Н.П. ГИПЕРБАРИЧЕСКАЯ ОКСИГЕНАЦИЯ КАК МЕТОД В КОМПЛЕКСНОМ ЛЕЧЕНИИ ИШЕМИИ НИЖНИХ КОНЕЧНОСТЕЙ}

\author{
Харьковская клиническая больница на железнодорожном транспорте №1, отделение \\ анестезиологии с койками для интенсивной терапии. \\ Харьковская клиническая больница на железнодорожном транспорте №2, отделение \\ анестезиологии с койками для интенсивной терапии.
}

\section{ВВЕДЕНИЕ}

Проблема поражения артериального русла нижних конечностей вследствие атеросклероза, сахарного диабета, эндартериита и других причин приводит к нарушению качества жизни и последующей инвалидизации пациентов.

\section{ЦЕЛЬ РАБОТЫ}

Определение эффективности гипербарической оксигенации (ГБО) как метода в комплексном лечении ишемической болезни нижних конечностей.

\section{МАТЕРИАЛЫ И МЕТОДЫ}

У пациентов после реконструктивных операций на артериальном русле подвздошно-бедренно-подколен- ного сегмента нередко сохраняются элементы ишемии в дистальных отделах стопы. С целью улучшения оксигенации ишемизированных дистальных участков, обеспечения условий для заживления большого массива травмированных операцией тканей, пациентам в раннем послеоперационном периоде проводится курс гипербарической оксигенации. При этом, начиная с первого дня после операции, пациенты получают кислородную баротерапию в барокамере БЛКС длительностью в один час. Как правило, этим пациентам проводится до 10 сеансов баротерапии. К сожалению, длительность курса часто обусловлена финансовыми возможностями пациента.

\footnotetext{
Федоров Ю.П, Прашерук П.В, Пугачев В.А, Меренков В.Г., Ковщарь Н.П., 2018

Федоров Ю.П, Пугачев В.А, Пращерук П.В, Антошкин Р.В., Ковшарь Н.П., 2018
} 
РЕЗУЛЬТАТЫ

Проведение сеансов ГБО в раннем периоде после реконструктивных сосудистых операций, улучшает течение раневого процесса, способствует разрешению ишемии тканей, ускоряя тем самым процесс выздоровления.

\section{MATEPIAЛИ КОНГРЕСУ AHECTEЗIOЛОГIВ УКРАÏH \\ 13-15 вересня 2018 року}

\section{ВЫВОДЫ}

Использование метода гипербарической оксигенации в комплексном лечении ишемии нижних конечностей является эффективным, улучшая прогноз и сокращая сроки пребывания пациента в стационаре.

\title{
Федоров Ю.П, Пугачев В.А, Пращерук П.В, Гречишкина Ю.А., Ковшарь Н.П. ГИПЕРБАРИЧЕСКАЯ ОКСИГЕНАЦИЯ КАК МЕТОД В КОМПЛЕКСНОМ ЛЕЧЕНИИ ГРЫЖ МЕЖПОЗВОНКОВЫХ ДИСКОВ ПОЗВОНОЧНИКА
}

\author{
Харьковская клиническая больница на железнодорожном транспорте №1, отделение \\ анестезиологии с койками для интенсивной терапии. \\ Харьковская клиническая больница на железнодорожном транспорте №2, отделение
}

\section{ВВЕДЕНИЕ}

Широкая распространенность спондилогенных заболеваний нервной системы дегенеративно-дистрофического происхождения определяет актуальность поиска различных способов их лечения.

\section{ЦЕЛЬ РАБОТЫ}

Определение эффективности и оптимальности метода гипербарической оксигенации (ГБО) в комплексном лечении грыж межпозвонковых дисков позвоночника.

\section{МАТЕРИАЛЫ И МЕТОДЫ}

Одним из наиболее тяжелых проявлений дегенеративнодистрофического процесса в межпозвонковых дисках является формированиеих грыжевого выпячивания. Вопрос терапии больных с грыжами межпозвонковых дисков позвоночника уже давно вышел за рамки чисто неврологической проблемы. Увлечение хирургическими методами лечения данного заболевания не всегда приводит к желаемому результату.

Баротерапия при воздействии на периферическую нервную систему не обладает прямым мио- и нейростиму- лирующим действием, а ее эффекты опосредуются главным образом сосудистыми реакциями. При этом наблюдается потенцирование вазоактивного и, как следствие, нейротрофического эффектов данного метода. Развивающиеся при этом гемоциркуляторный и нейрометаболический эффекты, а также повышение ферментативной активности, по всей видимости, являются оптимальными и оказывают обезболивающее и репаративное влияние на нервную ткань. Результаты. Гипербарическая оксигенация обеспечивает повышение эффективности лечения невральных нарушений, ускоряя тем самым процесс выздоровления и возвращение пациента к труду. Оптимальным в комплексной терапии является 10-12 сеансов ГБО.

\section{Выводы}

Гипербарическая оксигенация является одним из эффективных методов в комплексном лечении грыж межпозвонковых дисков позвоночника. При этом сокращая сроки пребывания пациента в стационаре.

Філімонов Р.В., Кобеляцький Ю.Ю., Поталов С.О., Філімонова І.В., Шаповалов Є.M.

\section{ОПЕРАТИВНЕ ЛІКУВАННЯ ХВОРИХ 3 СИНДРОМОМ ДІАБЕТИЧНОЇ СТОПИ В УМОВАХ РЕГIOHAPHOÏ AHЕCTEЗIÏ}

\section{АКТУАЛЬНІСТЬ}

Цукровий діабет визнано ВОО3 епідемією неінфекційного генезу. Одним з ускладнень даної патології є синдром діабетичної стопи - захворювання стоп, що виникає на тлі поразки периферичних нервів і судин [1].

У проведеному дослідженні, на базі відділення гнійної хірургії 3-ї міської клінічної лікарні міста Запоріжжя, було проведено порівняння декількох варіантів регіонарної анестезії (РА), які застосовували при хірургічних втручаннях на нижній кінцівці у хворих 3 цукровим діабетом, ускладнених синдромом діабетичної стопи. Це традиційна спінальна анестезія, одностороння спінальна анестезія і блокада сідничного нерва на стороні хірургічного втручання. Доведено, що у хворих, прооперованих в умовах односторонньої спінальної анестезії і блокади сідничного нерва, спостерігався більш стабільний рівень гемодинамічних показників в ході операції і в найближчому післяопераційному періоді, ніж у групи пацієнтів, прооперованих в умовах традиційної спінальної анестезії, незважаючи на проведену в даній групі хворих передопераційну інфузійну підготовку. У деяких випадках виконана блокада сідничного нерва не давала
$100 \%$ хірургічного знеболювання і було потрібно додаткове введення знеболюючих засобів.

\section{META РОБОТИ}

Оцінити ефективність методик регіонарної анестезії як методу знеболення при хірургічних втручаннях на стопі у хворих з синдромом діабетичної стопи.

\section{МАТЕРІАЛИ І МЕТОДИ}

Обстежено 96 пацієнтів, які проходили лікування у відділенні гнійної хірургії з діагнозом синдром діабетичної стопи. У всіх пацієнтів здійснювався моніторинг показників серцево - судинної системи (частота серцевих скорочень, артеріальний систолічний та діастолічний тиск, середній артеріальний тиск).

Сканування периферійного кровотоку проводили портативним звуковим індикатором швидкості кровотоку «МІНІДОП-8» 3 пальчиковою манжетою. 3 урахуванням показників доплерівського сканування кровотоку в нижній кінцівці пацієнта, вираховували Пальце-Плечовий Індекс.

\section{РЕЗУЛЬТАТИ}

На підставі t-критерію Стьюдента, достовірно виявлено $(\mathrm{p}<0,05)$, що показники гемодинаміки і рівень

\footnotetext{
Федоров Ю.П, Пугачев В.А, Пращерук П.В, Гречишкина Ю.А., Ковщарь Н.П., 2018

Філімонов Р.В., Кобеляиький Ю.Ю., Поталов С.О., Філімонова І.В., Шаповалов С.М., 2018
} 
поліпшення периферійної мікроциркуляції в нижніх кінцівках пацієнтів 3 синдромом діабетичної стопи в періопераційному періоді, при односторонній спінальної анестезії і блокаді сідничного нерва стабільніше, ніж при традиційній спінальній анестезії. У хворих, прооперованих в умовах односторонньої спінальної анестезії і блокади сідничного нерва спостерігався більш стабільний рівень гемодинамічних показників, практично були відсутні проблеми 3 сечовипусканням в післяопераційному періоді, на відміну від хворих, прооперованих в умовах традиційної спінальної анестезії.

\title{
ВИСНОВКИ
}

При хірургічному лікуванні хворих 3 синдромом діабетичної стопи, в умовах регіонарної анестезії, віддається перевага односторонній спінальній анестезії.

\section{СПИСОК ЛІТЕРАТУРИ}

1. Шаповал С.Д., Савон И.Л., Смирнова Д.А., Софилканыч М.М. Характеристика микроциркулячии нижних конечностей у пациентов с осложненным синдромом диабетической стопы Новости хирургии.- том 21.- № 3.-2013.-С.54-60.

\section{Фрончко В. П., Семицький Я. В., Мельник Р. В., Орлецький Б. Ю. ОЦІНКА ПОКАЗНИКА ВЕНТИЛЯЦІЙНОГО ТИСКУ ДЛЯ КОНТРОЛЮ МЕХАНІЧНОї ВЕНТИЛЯЦІї}

\section{АКТУАЛЬНІСТЬ ПРОБЛЕМИ}

Легенево-протективна вентиляція лишається основною стратегію респіраторної терапії у хворих як 3 важкою дихальною недостатністю, так і в пацієнтів без патології. Дотримання основних принципів протективної вентиляції (ДО 6-8 мл/кг ІМТ, піковий тиск не більше 35 см. водн. ст., тиск плато не більше 30 см. водн. ст.), насамперед, дозволяє мінімізувати ускладнення респіраторної терапії. У хворих 3 рефрактерною дихальною недостатністю як доповнення до вентиляції рекомендоване використання респіраторних (маневр рекруїтменту альвеол, МР) та нереспіраторних (прон-позиція) прийомів. Простим і доступним параметром, який дозволяє контролювати ефективність i безпеку респіраторної терапії, є показник вентиляційного (рушійного) тиску (Driving Pressure), який рекомендовано утримувати не вищим 15 см. водн. ст., $\Delta \mathrm{P}=$ Рплато - ПТКВ, [1, с. 755], [2, c. 1245$]$.

\section{META РОБОТИ}

Оцінити показник вентиляційного тиску $(\Delta \mathrm{P})$ в різних групах пацієнтів у відділенні анестезіології.

\section{МАТЕРІАЛИ I МЕТОДИ}

Показник вентиляційного тиску оцінювали в інтраопераційному періоді у 28 хворих, яким проведені оперативні втручання тривалістю понад 60 хвилин в умовах низькопоточної інгаляційної анестезії севораном: Групу I склали 17 пацієнтів без супутньої патології, групу II - 9 хворих 3 ожирінням, IMT $\geq$ кг $/ \mathrm{M}^{2}$. В дослідження включено 9 пацієнтів (група III) 3 рестриктивним типом дихальної

\author{
Луцьк, Україна
}

недостатності (ГРДС), рефракторною гіпоксемією $\left(\mathrm{SpO}_{2}<\right.$ $<88 \%$ при ПТКВ $>12$ см. водн. ст., $\left.\mathrm{FiO}_{2}>0,7\right)$. Параметри вентиляції обирали згідно принципів протективної концепції. Показник "Р визначали за форулою $\Delta \mathrm{P}=$ Рплато - ПТКВ.

\section{РЕЗУЛЬТАТИ}

Показник $\Delta \mathrm{P}$ у хворих I групи визначався в межах 10-13 см. водн. ст. У хворих II групи з ожирінням показник $\Delta \mathrm{P}$ склав 10-16 см. водн. ст. У хворих III групи при налаштуванні респіратора для отримання адекватних значень ДО, показник $\Delta \mathrm{P}$ нетривало був вищим рекомендованих значень, визначався в межах 1420 см. водн. ст.. Для покращення оксигенації в цій групі хворих ми застосовували маневр рекруїтменту 3 визначенням тиску відкриття і закриття альвеол та обиранням оптимального значення ПТКВ. У 2-ох померлих пацієнтів III групи $\Delta \mathrm{P}$ був вищим 15 см. водн. ст., складав 16-20 см. водн. ст.

\section{ВИСНОВКИ}

Налаштування параметрів вентилятора для отримання оптимальних значень вентиляційного тиску (не більше 15 см. водн. ст.) зменшує ризик ускладнень, покращує результати респіраторної терапії.

\section{СПИСОК ЛІТЕРАТУРИ}

Driving pressure and survival in the acute respiratory distress syndrome 7 Amato M.B., Meade M.O., Slutsky A.S. [et al.] // N. Engl. J. Med - 2015. - Vol. 372, Noo8. P. $747-755$

2. Optimal mechanical ventilation strategies to minimize ventilator-induced lung injury in non-injured and injured lungs / Pedro L. Silva, Paolo Pelosi, Patricia R. M. Rocco // Expert Review of Respiratory Medicine - 2016. - Vol. 10, №12. - P. 1243-1245.

\section{Хитрий Г.П., Мошківський В.М.}

\section{ОПТИМІЗАЦІЯ НАДАННЯ НЕВІДКЛАДНОЇ МЕДИЧНОЇ ДОПОМОГИ В ЗОНІ ПРОВЕДЕННЯ ООС ШЛЯХОМ ВПРОВАДЖЕННЯ УРГЕНТНОЇ СОНОГРАФІЇ}

\author{
Українська військово-медична академія \\ Кафедра анестезіології та реаніматології
}

\section{АКТУАЛЬНІСТЬ ПРОБЛЕМИ}

Особливість надання медичної допомоги під час збройних конфліктів - це етапність. Кваліфікована анестезіологічна та хірургічна допомога починається 3 так званих передових груп підсилення, які розгорнуті на базі ЦРЛ, близько розташованих до лілії зіткнення (Level II MTF за класифікацією НАТО). Вже на даному етапі потрібно намагатися використовувати всі можливі методи діагностики та лікування. Невідкладна ультразвукова діагностика (УЗД) бойової травми в передових групах підсилення є «білою плямою» у зв'язку з відсутністю, скоріше, не апарату УЗД, а спеціаліста, який здатний виконати дослідження.

\section{META}

Популяризувати використання невідкладної УЗД лікарями анестезіологами. Навчити методиці використання портативних апаратів УЗД при ургентній сонографії у поранених та травмованих пацієнтах, а саме FAST, BLUE, FAS-GIP, SHoC Protocol. Виконувати УЗД-асистовану катетеризацію центральних вен та провідникову анестезію.

\section{МАТЕРІАЛИ ТА МЕТОДИ}

Під час військових дій ультразвукове дослідження вперше використали в 1990 році в Перській затокі. Основою ургентної сонографії є FAST protocol. Даний термін з'явився у 1997 році під час International Consensus 
Conference, Focused Assessment with Sonography for Trauma (FAST). FAST протокол Ч стандартне дослідження при надання медичної допомоги за системою ATLS (Advanced Trauma Life Support).

Переваги методу:

1) Використання FAST протоколу дає відповідь на питання: чи є вільна рідина у черевній, грудній порожнині та перикарді? Чи є вільний газ у грудній, черевній порожнині? Відповідь на ці питання може кардинально змінити тактику лікування та відміняє рутинне використання лапароцентезу. 2) FAST протокол виконується біля «ліжка хворого» протягом 3-3,5 хв, навіть паралельно 3 реанімаційними заходами. Апарат УзД легко переміщати між пацієнтами. Не потрібно відвозити нестабільного пацієнта для виконання рентгенографії та чекати ії результатів.

FAST протокол - це своєрідний метод сортування.
Недоліки:

1) Ймовірність не виявити менше 150-200 мл вільної інтраперитоніальної рідини.

2) Рідко виявляє джерело та не відповідає на питання, що це за рідина?

3) В хворих з надмірною масою тіла та гіперпневматозом кишечника можуть виникнути труднощі при візуалізації органів черевної порожнини.

4) При відсутності досвіду оператор УзД частіше інтерпретує норму як патологію.

Ми на власному досвіді переконалися в легкості та ефективності даної методики. Співробітники кафедри під час відряджень в зону проведення ООС (операції об'єднаних сил) активно використовували ультразвукову діагностику при невідкладних станах та УЗД асистуванні анестезіологічних маніпуляцій, що якісно покращило

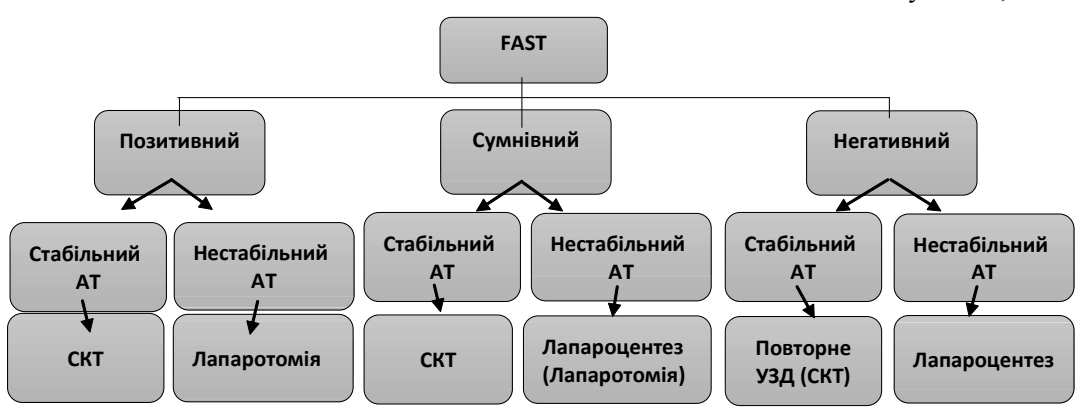

3) Має чутливість 63-100\%, специфічність 90-100\% при наявності більше 150 мл рідини в черевній порожнині. Чутливість $100 \%$, специфічність 99,7\% при наявності більше 50 мл рідини в плевральні порожнині, проти 43\% чутливості рентгенографії в положенні лежачи. При пошуку пневмотораксу УЗД дає чутливість 95-100\% за точністю прирівнюється до спіральної комп'ютерної томографії (СКТ), в той же час ймовірність виявити пневмоторакс при рентгенографії лежачи $36-75 \%$.

4) При сумнівному результаті та стабільній гемодинаміці легко проводити динамічний огляд пацієнта 3 метою вибору остаточної тактики лікування.

5) FAST протоколу легко навчити. Лікар, який прослухав курс лекції та виконав 10-20 досліджень, вже здатний до самостійної роботи.

6) Відсутність ускладнень та негативного впливу на організм. надання невідкладної медичної допомоги та діагностичного пошуку в поранених та травмованих пацієнтів.

\section{ВИСНОВКИ}

Роль невідкладної УЗД лікарями не радіологічних спеціальностей недооцінена. Широке впровадження даних методик в зоні проведення ООС зменшить хірургічну інтервенцію та поліпшить результати лікування поранених та травмованих пацієнтів. 3 метою покращення підготовки в ЗСУ лікарів-анестезіологів 32018 року на кафедрі анестезіології та реаніматології Української військовомедичної академії розпочнеться викладання циклу ТУ «Використання ультразвукових методів діагностики в анестезіології та інтенсивній терапії».

\section{СПИСОК ЛІТЕРАТУРИ}

Emergency Ultrasound, Second Edition. O. John Ma, James R. Mateer, Michael Blaivas. McGraw Hill Professional, 2007. P.- 77-108

2. Pocket Atlas of Emergency Ultrasound, Second Edition. Robert F. Reardon, O. John Ma, Andrea Rowland-Fisher. McGraw Hill Professional, 2017. P. 29-60

Chest sonography, Fourth edition. Gebhard Mathis. Springer Internationol Publishing Chest sonography, Fourth edition.
Switzerland 2017. P. 209-217.

\title{
Хитрий Г.П. ${ }^{1}$, Хромихіна Н.А. ${ }^{2}$, Гладуш А.В. ${ }^{2}$, Хорошун В.М. ${ }^{2}$, Чуйко Ю.М. ${ }^{2}$ ОСОБЛИВОСТІ АНЕСТЕЗІОЛОГІЧНОЇ ДОПОМОГИ ПОСТРАЖДАЛИМ ПРИ ВОГНЕПАЛЬНИХ ПОРАНЕННЯХ В УМОВАХ ЗБРОЙНОГО КОНФЛІКТУ
}

\author{
1 Українська військово-медична академія, м. Київ, Україна, grighit@i.ua \\ ${ }^{2}$ КЗОЗ "Бахмутська центральна районна лікарня», м. Бахмут, Донецька обл., Україна
}

\section{META РОБОТИ}

Провести ретроспективний аналіз анестезіологічної допомоги постраждалим при вогнепальних пораненнях в умовах збройного конфлікту на Сході України.

\section{МАТЕРІАЛИ ТА МЕТОДИ}

Проведено ретроспективний аналіз анестезіологічної допомоги постраждалим при вогнепальних пораненнях в Бахмутській центральній районній лікарні (ЦРЛ) в умовах збройного конфлікту на Сході України за період з 13 квітня 2014 року по 31 грудня 2017 року. Анестезіологічна допомога надавалась 460 постраждалим 3 вогнепальними пораненнями, серед них військово- службовців було $356(77,4 \%)$ і $104(22,6 \%)$ - цивільні особи. Всіх постраждалих оперували в ургентному порядку. Стабілізація стану поранених здійснювалась до операції, в операційній під час оперативного втручання, а також в післяопераційному періоді з дотриманням принципів «Damage Control Surgery» $\mathrm{i}$ «Damage Control Resuscitation».

У зв'язку з відсутністю на початку збройного конфлікту військових госпіталів первинна невідкладна допомога пораненим, у тому числі і анестезіологічна, надавалась в цивільних лікувальних закладах. Перші поранені поступили до Бахмутської ЦРЛ у квітні 2014 року. 3 січня

\footnotetext{
Хитрий Г.П., Хромихіна Н.А., Гладуши А.В., Хорошун В.М., Чуйко Ю.М., 2018
} 
2015 року допомогу пораненим разом 3 цивільними анестезіологами надавали військові анестезіологи анестезіологи з Українського НПЦ ЕМД та МК. 3 листопада 2016 року по теперішній час на базі Бахмутської ЦРЛ працює група підсилення 3 військових лікарів і медичних сестер у складі торако-абдомінального хірурга, нейрохірурга, судинного хірурга, травматолога, анестезіолога, операційної медичної сестри та медичної сестри анестезиста. Термін доставки постраждалих до лікарні складав в середньому 1-2 години після отримання поранення.

\title{
РЕЗУЛЬТАТИ
}

Було встановлено, що до відділення травматології поступило 317 поранених (військовослужбовців - 226, цивільних - 91), до хірургічного відділення - 143 поранених (військовослужбовців - 130 , цивільних - 13). За роками було госпіталізовано: 2014 рік (8,5 місяців) - 101 постраждалий, 2015 рік - 218 пацієнтів, 2016 рік - 84 особи, 2017 рік - 57 осіб. Серед вогнепальних поранень кульових було $25,7 \%$, осколкових $-16,1 \%$, мінно-вибухових $-58,2 \%$. Переважну більшість вогнепальних поранень склали ізольовані $-67,1 \%$, множинні - $11,6 \%$, поєднана вогнепальна травма відмічалась у $21,3 \%$ постраждалих.

3460 проведених анестезій загальна анестезія з інтубацією трахеї та ШВЛ була використана у 323 поранених $(70,22 \%)$,

внутрішньовенна анестезія - у 113 пацієнтів (24,57\%), спинномозкова анестезія - у 19 (4,13\%), провідникова - у 3 $(0,65 \%)$, епідуральна анестезія - у 2 постраждалих $(0,43 \%)$. За необхідності постраждалим проводились реанімаційні заходи, стабілізація стану та підтримуюча терапія. Після стабілізації стану здійснювали аеромедичну або автомобільну евакуацію поранених на наступні рівні медичної допомоги. Евакуація тяжкопоранених, як правило, здійснювалась у супроводі лікаря-анестезіолога та медичної сестри-анестезиста. Відмічено 29 летальних наслідків (6,3\%), 3 яких військовослужбовців - 22 чоловіка, 7 чоловік цивільні особи. Причиною летальних наслідків були масивна крововтрата та отримані вогнепальні поранення несумісні 3 життям.

\section{ВИСновкИ}

1. Внаслідок вдосконалення лікувально-евакуаційної системи поранені стали потрапляти на етап надання кваліфікованої медичної допомоги в середньому не більше, ніж через дві години після поранення (за сприятливих умов навіть протягом години).

2. Запроваджено максимальне наближення кваліфікованої хірургічної та анестезіологічної допомоги до зони бойових дій на базі районних та міських лікарень за рахунок підсилення їх військовими хірургами та анестезіологами.

\section{Черній B. І., Євсєєва В. В. ЧИ $€$ АЛЬТЕРНАТИВА ФЕНТАНИЛУ В СХЕМІ ІНТРАОПЕРАЦІЙНОЇ МУЛЬТИМОДАЛЬНОЇ АНАЛГЕЗІЇ ПІД ЧАС ЛАПАРОСКОПІЧНИХ БАРІАТРИЧНИХ ВТРУЧАНЬ У ПАЦІЕНТІВ 3 МОРБІДНИМ ОЖИРІННЯМ?}

\author{
Державна наукова установа "Науково-практичний центр профрілактичної та клінічної медицини" \\ Державного управління справами, м. Київ, Україна
}

\begin{abstract}
АКТУАЛЬНІСТЬ
Не дивлячись на гарний аналгетичний ефект, наркотичні анальгетики несуть значний ризик і небезпеку при морбідному ожирінні: ризик гіпералгезії, негативний вплив на імунну систему, збільшення частоти післяопераційних нудоти та блювання та найважливіше - пригнічення дихання у пацієнтів з синдромом сонного апное. Тому розробка альтернативних схем періопераційного знеболення в баріатричній хірургії $є$ перспективним напрямком .

Метою роботи $є$ порівняння аналгетичної дії фентанілу та налбуфіну в якості основних аналгетичних агентів в схемі інтраопераційної мультимодальної анестезії у пацієнтів 3 морбідним ожирінням під час лапароскопічних баріатричних втручань.
\end{abstract}

\section{МАТЕРІАЛИ І МЕТОДИ}

В дослідження було включено 18 хворих на морбідне ожиріння, 8 чоловіків та 10 жінок віком від 28 до 60 років 3 IBM 37-55, яким за період з 2016 по 2018 рік в ДНУ “НПЦ ПКМ” ДУС, були виконані лапароскопічні баріатричні втручання. 17 пацієнтам була виконана лапороскопічна sleeve-резекція шлунку та 1 пацієнту було виконано лапароскопічне шунтування шлунку. У всіх пацієнтів була реалізована програма прискореного ведення періопераційного періоду. Пацієнти були рандомізовані на 2 групи. До першої групи (n1=9) увійшли пацієнти, що в якості основного аналгетичного компонента інтраопераційно отримували фентаніл внутрішньовенно у складі мультимодальної аналгезії. В другу групу (n2=9) - пацієнти, що в якості основного аналгетичного компонента інтраопераційно отримували налбуфін внутрішньовенно у складі мультимодальної аналгезії. Інтраопераційний моніторинг пацієнта включав: неінвазивне вимірювання артеріального тиску, частоти серцевих скорочень, пульсоксиметрію, ЕКГ, показники центральної гемодинаміки (математичним методом), визначення концентрації кисню, вуглекислого газу та інгаляційного анестетика на вдиху і видиху, реєстрацію біспекторального індексу в режимі on-line. Інтраопераційно так само визначалися показники КОС, електролітів, глюкози крові, венозної сатурації. Оцінка болю за ВАШ проводилась вперше на операційному столі, одразу після екстубації трахеї, далі - через $2,4,12$ та 24 години після операції двічі (перед знеболюванням та через 30 хв. після знеболення). Статистична обробка результатів дослідження здійснювалась за допомогою пакету аналізу статистичних даних EZR (R-Statistics) та авторського пакету "Medstat" (Лях Ю. С., Гурьянов В. Г., 20042011 р.p.). Використовувався крітерій Фішера.

\section{РЕЗУЛЬТАТИ}

Наведені данні свідчать, що показники гемодинаміки в обох групах суттєво не відрізнялися між собою впродовж операції та знаходилися в межах інтраопераційної стреснорми. Рівень болю за ВАШ у пацієнтів в обох групах був в середньому 2-4 бали, відповідно в наркотичних анальгетиках необхідності не було. У пацієнтів групи фентанілу показники рівню болю за ВАШ впродовж першої післяопераційної доби суттєво не відрізнялись від пацієнтів групи налбуфіну, але мали статистично незначущу тенденцію до зростання до 4 післяопераційної години, ймовірно, обумовлене тим, що налбуфін має більш подовжену аналгетичну дію порівняно 3 фентанілом.

\section{ВИСНОВКИ}

1. Налбуфін є ефективним та безпечним аналгетичним компонентом в складі мультимодальної інтраопераційної аналгезії при лапароскопічних баріатричних втручаннях у пацієнтів 3 морбідним ожирінням та $є$ альтернативою фентанілу.

Черній В. I., Євсєєва В. В., 2018 


\title{
Шкурупій Д.А., Терів П.С.
}

\section{ПРОГНОСТИЧНІ ФАКТОРИ РОЗВИТКУ НЕДОСТАТНОСТІ ЦИНКУ У НЕВРОЛОГІЧНИХ ХВОРИХ, ЯКІ ПОТРЕБУЮТЬ ІНТЕНСИВНОЇ ТЕРАПІЇ}

Вищий державний навчальний заклад України "Українська медична стоматологічна академія» м. Полтава, Україна

\section{АКТУАЛЬНІСТЬ ПРОБЛЕМИ}

Розвиток системної запальної відповіді, ішемія та місцева імунна дисрегуляція шлунково-кишкового тракту, пізній початок ентерального харчування у хворих в умовах інтенсивної терапії (IT) у $62 \%$ створюють умови для порушення утилізації нутрієнтів, зокрема - цинку, який є системним біорегулятором, в т.ч - і нервової системи $[1,2]$.

\section{META РОБОТИ}

Визначення прогностичних факторів розвитку цинково недостатності у неврологічних пацієнтів відділень IT

\section{МАТЕРІАЛИ ТА МЕТОДИ}

Проведено обстеження 60 пацієнтів неврологічного профілю, які потребували IT. У всіх пацієнтів фіксували стать, вік, клінічні характеристики пацієнта, медикаментозну підтримку. Пацієнти були розділені на 2 групи залежно від вмісту цинку крові: основна група $(\mathrm{n}=21)$ пацієнти 3 гіпоцинкемією, група порівняння - пацієнти нормальним вмістом цинку $(\mathrm{n}=39)$. Граничним порогом нормального вмісту цинку вважали 13 ммоль/л [3] Статистичний аналіз проводили 3 обчисленням нормованого інтенсивного показника (НІП) [4].

\section{РЕЗУЛЬТАТИ}

Встановлено, що прогностично значимим факторами ризику розвитку недостатності цинку у неврологічних пацієнтів в умовах IT є:

- чоловіча стать пацієнта $(\mathrm{HIП}=1,4)$;

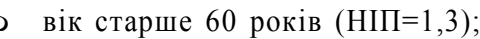

ознаки синдрому системної запальної відповіді $($ НІП=1,7);

○ наявність гастроінтестинальної недостатності (НIП=1,7);

○ артеріальний перфузійний тиск менше 89 мм.рт.ст. (НІП=1,3);

○ проведення штучної вентиляції легень (НIП=1,2);

○ потреба в призначенні атарактиків (НIП=1,3);

- рівень свідомості за шкалою FOUR менше 10 балів $(\mathrm{HI \Pi =1,4)}$;

○ тяжкість стану за шкалою SAPS більше 9 балів

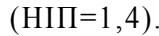

\section{ВИСНОВок}

Характеристики статі, віку, параметрів дихальної, гемодинамічої, гастроінтестинальної, нервової систем, тяжкості стану, медикаментозної підтримки можуть бути використані для прогнозування розвитку недостатності цинку у неврологічних пацієнтів відділень IT.

\section{СПИСОК ЛІТЕРАТУРИ}

Андрюшенко В.П. Синдром ентеральної недостатності при гострому панкреатиті: патоморфологічні зміни слизової оболонки тонкої кинки та мияки їі медикаментозної корекиї // Харківська хірургічна школа - 2008 - № 2 (29) - C. 72-75.

2. Баринов А.Н. Роль окислительного стресса в заболеваниях нервной системы - пути коррекции // Трудный пациент. - 2012. - Т. 10, № 1. C. $10-13$.

3. Алиева T. К Кончентрачия чинка и иеди в плазме крови у больных с гнойными ранами мягких тканей // Анестезиология и реаниматология. - 2010. - N 3. - C. 8-12

4. Петров А.Г., Кным О.И., Петров Г.П. Методические подходы к прогнозированию позитивного корпоративного имиджа фармацевтических организаций // Бюллетень сибирской медицины.-2010. № 1.- C. 130-135.

\section{Шкурупій Д.А., Холод Д.А.}

\section{ГАСТРОІНТЕСТИНАЛЬНА НЕДОСТАТНІСТЬ В СТРУКТУРІ ГІПОКСИЧНО- ІШЕМІЧНИХ УРАЖЕНЬ НОВОНАРОДЖЕНИХ: МЕХАНІЗМИ ФОРМУВАННЯ ТА КОРЕКЦІЯ}

\author{
Вищий державний навчальний заклад України "Українська медична стоматологічна академія» \\ м. Полтава, Україна
}

\section{АКТУАЛЬНІСТЬ ПРОБЛЕМИ}

Ішемія тканин з розвитком тканинної гіпоксії і клітинного гіпоергозу є універсальним механізмом критичних станів. У новонароджених такі механізми, як правило, є наслідком асфіксії при народжені. Як клінічні прояви цього стану описані гіпоксично-ішемічні ураження мозку, міокарду, нирок, але патогенез синдрому гастроінтестинальної недостатності (СГІН) як прояву гипоксично-ішемічних уражень кишечника у новонароджених $є$ мало дослідженим $[1,2]$.

\section{META РОБОТИ}

Обгрунтування тактики оптимізації інтенсивної терапії у новонароджених із СГІН на основі дослідження механізмів гіпоксично-ішемічних уражень травної системи.

\section{МАТЕРІАЛИ ТА МЕТОДИ}

Проаналізовані випадки захворювання 110 новонароджених із наявністю СГІН, які перебували на лікуванні у неонатальних відділеннях інтенсивної терапії. Визначали виразність СГІН, концентрацію сироваткового вмісту молочної (МК), піровиноградної кислот (ПВК), їх співвідношення, активність сукцинатдегідрогенази (СДГ) крові на початку та наприкінці дослідження в залежності від тактики інтенсивної терапії: із додатковим введенням препаратів на основі бурштинової кислоти (основна група; $\mathrm{n}=66$ ) та без такого (група порівняння; $\mathrm{n}=44$ ).

\section{РЕЗУЛЬТАТИ}

У обстежених новонароджених на початку дослідження спостерігалась тенденція до формування лактат-ацидозу, при цьому не було встановлено значимого кореляційного зв'язку між виразністю СГІН і показниками цитоенергетичного забезпечення як в окремих групах, так i в цілому. Наприкінці дослідження у новонароджених основної групи відносно групи порівняння були констатовані зменшення рівня МК і підвищення рівня ПВК, що відобразилось на зменшенні їх співвідношення. Також на тлі прийому препаратів бурштинової кислоти було констатовано підвищення активності СДГ. При цьому

\footnotetext{
Шкурупій Д.А., Терів П.С., 2018

- Шкурупій Д.А., Холод Д.А., 2018
} 
був встановлений прямий значимий кореляційний зв'язок між виразністю СГІН і рівнем МК.

\section{ВИСновкИ}

У новонароджених із СГІН, які потребують проведення інтенсивної терапії, наявні метаболічні маркери клітинного гіпоергозу, що свідчить про наявність гіпоксично-ішемічних уражень гастроінтестинально системи. Призначення препаратів бурштинової кислоти в комплексі інтенсивної терапії дозволяє покращити стан клітинного енергозабезпечення, зменшуючи прояви лактат-ацидозу і призводять до зменшення виразності і прогресування СГІН у новонароджених.

\section{СПИСОК ЛІТЕРАТУРИ}

1. Интенсивная терапия : национальное руководство : в $2 \mathrm{~m}$./ под ред. Б.Р. Гельфанда, А.И. Салтанова. - М. : ГЭОТАР-Медиа, 2009. T. I. $-960 \mathrm{c}$.

2. Македонський І.О. Сучасні можливості діагностики та хірургічного лікування некротичного ентероколіту новонароджених (оглядова стаття) / I.О. Македонський, С.О. Яременко // Неонатологія, хірургія та перинатальна медицина. 2015.- T.V, № 3(17). - c. 116-127.

\section{Якобчук Х.P. \\ МОНІТОРИНГ НЕЙРОМ'ЯЗОВОЇ ПРОВІДНОСТІ ПРИ ОПЕРАТИВНИХ ВТРУЧАННЯХ НА ЧЕРЕВНІЙ ПОРОЖНИНІ}

\section{вступ}

Інструментальні методи вимірювання глибини анестезії i акцелерометричний моніторинг нейром'язової провідності можуть значно покращити якість і безпеку анестезії, за рахунок зниження вірогідності інтранаркозного пробудження, зменшення часу знаходження хворого в операційній, а також контролю залишкової кураризації.

\section{META РОБОТИ}

Створити та відпрацювати алгоритми безпечного керування глибиною анестезії і нейром'язової провідності на етапах швидкої послідовної індукції і виходу з анестезії.

\section{МАТЕРІАЛИ ТА МЕТОДИ ДОСЛІДЖЕННЯ}

Нами обстежено 50 пацієнтів, госпіталізованих у НВМКЦ «ГВКГ» $32016-2017$ рр. Порівнювали 2 групи хворих, яким проводились абдомінальні оперативні втручання. У I групі хворих застосовували TOFмоніторинг, для визначення глибини НМБ, а в II групі визначали ступінь НМП по реакції хірургів і часу, згідно інструкції міорелаксанту.

\section{РЕЗУЛЬТАТИ}

Пацієнти були поділені на групи у зв'язку з методом визначення НМБ. 1 група хворих, яким проводились абдомінальні оперативні втручання: л/т міомектомія, пангістеректомія, л/с міомектомія, цистектомія, оваріектомія, тубектомія, апендектомія, ЛХЕ використанням TOF-моніторингу. 2 група - хворі, яким також були проведені такі ж абдомінальні операції, але ступінь НМБ визначали по реакції хірурга. У 1-й групі було 25 пацієнтів, 3 них 22 жінки і 3 чоловіка. Середній вік хворих у 1-й групі 34,68 років, у 2 -й групі було 25 пацієнтів, 3 них - 23 жінки і 2 чоловіка, середній вік обстежуваних даної групи становив - 46,44 роки.

Всім пацієнтам за 30 хвилин до поступлення в операційну призначали промедол $2 \% 1$ мл. $1,5-2$ мг/кг, тіопенталом натрію $1 \%$ в дозі $2-3$ мг/кг (13 хворим 1-ї групи, 4 хворим 2-ї групи).

Для знеболення використовували фентаніл $0,005 \%$ в дозі 0,001-0,003 мг/кг.

У всіх групах для забезпечення міорелаксації для інтубації і підтримання міоплегії під час операції застосовувались міорелаксанти короткої дії (дитилін в дозі 1,5-2 мг/кг), середньої (рокуроній бромід в дозі 0,6 мг/кг - для інтубації, 0,15-0,18 мг/кг для підтримання релаксації) та тривалої дії (піпекуроній 0,06-0,07 мг/кг для інтубації, 0,01-0,02 мг/кг для підтримання міорелаксації). Підтримуючу дозу міорелаксанта в першій групі вводили при виявленні другої відповіді на TOFстимуляцію, в другій групі - за зауваженнями хірургів чи даними інструкції.

При виході з анестезії оцінювали рівень свідомості і глибину НМБ, при показниках ТOF > 0,9 в першій групі, а в другій групі - наявність і ефективність самостійного дихання, можливість хворого висунути язик, підняти i утримувати голову > 3 секунд, потискати руку. Порівнювали тривалість перебування хворих в операційній після завершення оперативного втручання.

\section{ВИСНОВОК}

Таким чином виявлено, що в першій групі проводилась своєчасна екстубація, всі хворі не пам'ятали про наявність інтубаційної трубки, тривалість перебування хворих в операційній по закінченню операції була меншою в порівнянні з 2-ю групою. У 1-й групі деяким пацієнтам після екстубації була потреба проводити ШВЛ лицевою маскою, 3 пацієнтам - проводилась декураризація прозерином в дозі 1-2 мг і атропіном 0,5-0,7 мг, 5 пацієнтів транспортувались в ВРІT для п/ о нагляду, 20 хворих пам'ятали наявність інтубаційної трубки. 


\title{
МАТЕРІАЛИ КОНГРЕСУ АНЕСТЕЗІОЛОГІВ УКРАЇНИ
}

\author{
13-15 вересня 2018 року
}

АНДРУЩАК А.В., КОНОВЧУК В.М., КУШНІР С.В

ОСОБЛИВОСТІ ВОЛЮМО- ТА ОСМОРЕГУЛЯТОРНОЇ ФУНКЦІЇ НИРОК У ПАЦІЄНТІВ І3

КОМПЕНСОВАНОЮ СЕПСИС-ІНДУКОВАНОЮ ГІПОТЕНЗІЄЮ

БАБІНЦЕВА А.Г., ГОДОВАНЕЦЬ Ю.Д., АГАФОНОВА Л.В., ФРУНЗА А.В.

ГОСТРЕ ПОШКОДЖЕННЯ НИРОК У НОВОНАРОДЖЕНИХ ДІТЕЙ: ОСНОВНІ ПРИНЦИПИ

ПРОФІЛАКТИКИ ТА ІНТЕНСИВНОÏ ТЕРАПІЇ В РАННЬОМУ НЕОНАТАЛЬНОМУ ПЕРІОДІ

БЄЛИХ О.В

ВИВЧЕННЯ ПРОБЛЕМИ ЗАСТОСУВАННЯ РЕГІОНАРНИХ МЕТОДІВ АНЕСТЕЗІЇ

ПРИ ЛАПАРОСКОПІЧНИХ ОПЕРАЦІЯХ В ОСІБ ПОХИЛОГО ВІКУ

БІГНЯК П.І., ГОМОН М.Л., ДАЦЮК О.І.

ПОРУШЕННЯ ЕЛЕКТРОЛІТНОГО БАЛАНСУ ПРИ ТРАДИЦІЙНІЙ ПЕРЕДОПЕРАЦІЙНІЙ ПІДГОТОВЦІ ХІРУРГІЧНИХ ХВОРИХ

БОДУЛєВ О.Ю., ШКУРУПІЙ Д.А

МЕТОДИ СУБ'ЄКТИВНОЇ ОЦЦІККИ ЯКОСТІ СНУ У ХВОРИХ В ПЕРИОПЕРАЦІЙНОМУ ПЕРІОДІ

ВИГОНЮК А.В., ГОНЧАРУК О.С., ГОМОН М.Л., КОСЕЧЕНКО Н.Ю., МАСЛІЙ В.А

ОСОБЛИВОСТІ ФОРМУВАННЯ БОЛЬОВОЇ РЕАКЦІЇ В ПІСЛЯОПЕРАЦІЙНОМУ ПЕРІОДІ ПРИ ВИКОРИСТАННІ ЗАГАЛЬНОГО ЗНЕБОЛЮВАННЯ

ГЕОРГІЯНЦ М.А., КОРСУНОВ В.А., СТОЛЯРОВ К.Є., ПОРОША Н.С., ЗУБКО В.В.

СТАН ЦЕРЕБРАЛЬНОÏ ГЕМОДИНАМІКИ ТА МОЖЛИВОСТІ ЙОГО ПОК РАЩЕННЯ

ПРИ ТЯЖКИХ ФОРМАХ НЕИРОІНФЕКЦІЙ У ДІТЕЙ

ГЕОРГІЯНИ М.А., КОРСУНОВ В.А., СТОЛЯРОВ К.Є., ПОРОША Н.С., ЗУБКО В.В

МЕНІНГОКОКОВА ІНФЕКЦІЯ У ДІТЕЙ. МИНУЛЕ ТА МАЙБУТНЄ ІНТЕНСИВНОÏ ТЕРАПІЇ

ГОРКАВЫЙ Е.А ЛЕСНОЙИ И

СРАВНЕНИЕ МЕТОДОВ ПЕРИОПЕРАЦИОННОГО ОБЕЗБОЛИВАНИЯ

ПРИ ХИРУРГИЧЕСКОМ ЛЕЧЕНИИ РАКА ПРЯМОЙ КИШКИ

ГРИЦЕНКО С.Н., МИЗИНЕНКО И.В.

ИНТЕНСИВНАЯ ТЕРАПИЯ ТРОМБОЭМБОЛИИ ЛЕГОЧНОЙ АРТЕРИИ

ГУБАНОВА О.В., ГЕОРГІЯНЦ А М.

ВИБІР АНЕСТЕЗІОЛОГІЧНОЇ ТАКТИКИ ПРИ ХІРУРГІЧНІЙ КОРЕКЦІЇ ВРОДЖЕНИХ ВАД

НИЖНІХ КІНЦІВОК У ДІТЕЙ РАННЬОГО ВІКУ В ЗАЛЕЖНОСТІ ВІД КОМБОРБІДНОСТІ

ГУРІН П.В

ВПЛИВ РОЗЧИНІВ ГІДРОКСИЕТИЛКРОХМАЛІВ НА КОАГУЛЯЦІЙНИЙ ГЕМОСТАЗ ПІД ЧАС

КОРОНАРНОГО ШУНТУВАННЯ НА ПРАЦЮЮЧОМУ СЕРЦІ

ДАЦЮК О.І., ГОМОНМ.Л., ДАЦЮКЛ.В.

МОЗКОВА ТА РЕСПІРАТОРНА ДИСФУНКЦІЯ - ЯК ПРЕДИКТОРИ СИНДРОМУ ПОЛІОРГАННОЇ

НЕДОСТАТНОСТІ ПРИ ВАЖКОМУ ГОСТРОМУ ПАНКРЕАТИТІ

ДЗЮБА Д.О., ВЕРЕЩАГІН С.В.

МОЖЛИВОСТІ ЗАСТОСУВАННЯ КАУДАЛЬНОЇ АНЕСТЕЗІЇ В РЕНТГЕНЕНДОВАСКУЛЯРНІЙ ХІРУРГІЇ

ДМИТРИШИНА Є.О.

НОЗОКОМІАЛЬНІ ПНЕВМОНІЇ У ОПЕРОВАНИХ ХВОРИХ ТА ПОРАНЕНИХ

ДОРОШ О. І., ЩУРОВСЬКА І. П.

СЕПТИЧНІ УСКЛАДНЕННЯ У ХВОРОГО НА ГОСТРУ МІєЛОЇДНУ ЛЕЙКЕМІЮ: КЛІНІЧНИЙ ВИПАДОК

ЕМЕЛЬЯНОВА Е.А., ТРЕГУБЕНКО С.А., ШЕЛЕСТ Т.В.. ТОРЯНИК Р.М., БРЕУС М.И.

ПЕРВЫЙ СЛУЧАЙ УСПЕШНОГО ОПЕРАТИВНОГО ЛЕЧЕНИЯ СТЕНОЗА ТРАХЕИ В Г. КРИВОМ РОГЕ 
ЕМЕЛЬЯНОВА Е.А., ШЕЛЕСТ Т.В.

РЕТРОСПЕКТИВНЫЙ АНАЛИЗ ОСЛОЖЕНИЙ ТРАХЕОСТОМИИ

ЙОВЕНКО И.А., БАЛАКА И.В., КОРЕНЮК Д.Е., КОБЕЗКАЯ О.Г.

ИНФУЗИОННАЯ ТЕРАПИЯ КРИТИЧЕСКИХ СОСТОЯНИИ: ПАТОФИЗИОЛОГИЧЕСКИЙ ПОДХОД

ЙОВЕНКО И.А., КОБЕЛЯЦКИЙ Ю.Ю., ЦАРЕВ А.В., КУЗЬМОВА Е.А., МЫНКА В.Ю., СЕЛЕЗНЕВА У.В. ОСТРАЯ ТРАВМАТИЧЕСКАЯ КОАГУЛОПАТИЯ: СТАНДАРТЫ ИТ

КАНІКОВСЬКИЙ О.Є., ОСАДЧИЙ А.В. МОСЬОНДЗ В.В.

ОБҐРУНТУВАННЯ ДЕТОКСИКАЦІЙНОЇ ТЕРАПІЇ ПРИ ГНІЙНО-НЕКРОТИЧНОМУ ВРАЖЕНІ

ПАРАРЕКТАЛЬНОÏ ДІЛЯНКИ, НЕКРОТИЧНОМУ ФАСЦИЇТІ

КЛЕВАКІНА О.Ю., АНІКІН І.О

КРИТЕРІЇ ЗАСТОСУВАННЯ НЕІНВАЗИВНОЇ ВЕНТИЛЯЦІЇ ЛЕГЕНЬ У ДОНОШЕНИХ

НОВОНАРОДЖЕНИХ ІЗ ВАЖКОЮ ГІПОКСИЧНО-ІШЕМІЧНОЮ ЕНЦЕФАЛОПАТІЄЮ

КЛИГУНЕНКО Е.Н. КРАВЕЦ О.В

АНАЛИЗ СОСТОЯНИЯ ВОДНЫХ СЕКТОРОВ И ЦЕНТРАЛЬНОЙ ГЕМОДИНАМИКИ У БОЛЬНЫХ

В УРГЕНТНОЙ АБДОМИНАЛЬНОЙ ХИРУРГИИ ПРИ РЕСТРИКТИВНОИ ИНФУЗИОННОЙ ТАКТИКЕ

КОВАЛЬ О.І., КОВАЛЬ П.Б

СИСТЕМНІ НЕВІДКЛАДНІ СТАНИ В ДИТЯЧІЙ АМБУЛАТОРНІЙ СТОМАТОЛОГІЇ

КОВАЛЬП.Б

МОНИТОРИНГ ТКАНЕВОЙ ОКСИГЕНАЦИИ ВО ВРЕМЯ ЛАПАРОСКОПИЧЕСКИХ

АБДОМИНАЛЬНЫХ ОПЕРАЦИЙ

КОВАЛЬОВА О.В., МАЛЯРЕНКО Ю.О., КОВАЛЬОВА О.В., КОШЛЯ О.В.

УСУНЕННЯ ЦЕФАЛГІЇ ПРИ КОМПЛЕКСНОМУ ЛІКУВАННІ ГІПЕРТОНІЧНОГО КРИЗА ТЛІ ПАТОЛОГІЇ ШИЙНОГО ВІДДІЛУ ХРЕБТА

КОВАЛЬОВА О В СТРОКАНЬ В В. ТАРАН ГІ КОВАЛЬОВА О В

ЗАСТОСУВАННЯ МОДУЛЬОВАНОГО ЕЛЕКТРИЧНОГО СТРУМУ ПРИ КОМПЛЕКСНОМУ ЛІКУВАННІ БОЛЬОВОГО СИНДРОМУ

КОВТУН А.І., БОЙКО Ю.Г., КОВТУН О.А., КИФЯК П.В., МАРТИМ'ЯНОВ А.Ю.

ВПРОВАДЖЕННЯ СУЧАСНИХ МЕТОДІВ ЕФЕРЕНТНОЇ ТЕРАПІЇ У ЛІКУВАННЯ ХВОРИХ

У КРИТИЧНОМУ СТАНІ

KOVTUN A.I., KONOVCHUK V.M., KOVTUN O.A., MARTIMIANOV A.E.

INFLUENCE OF HYPERBARIC OXYGENATION ON KIDNEY FUNCTION IN PATIENTS WITH

PURULENT-SEPTIC COMPLICATIONS

КОЛОМАЧЕНКО В.I.

ІНЦИДЕНТНІСТЬ НЕБАЖАНИХ ЯВИЩ ПРИ ЕНДОПРОТЕЗУВАННІ КУЛЬШОВОГО СУГЛОБА

В УМОВАХ РІЗНИХ ВИДІВ ЗНЕБОЛЮВАННЯ

КОРОБКО Е.Ю., ГЕОРГІЯНЦ М.А., КРИВОБОК В.І.

ВИБІР МЕТОДУ КОМБІНОВАНОÏ АНЕСТЕЗІЇ У ХВОРИХ ТРАВМАТОЛОГІЧНОГО ПРОФІЛЮ

КРЕНЬОВ К.Ю

АБДОМІНАЛЬНИЙ ПЕРФУЗІЙНИЙ ТИСК, ЯК ПРЕДИКТОР ЛЕТАЛЬНОСТІ У ПАЦІЄНТІВ

ІЗ ГОСТРОЮ ХІРУРГІЧНОЮ ПАТОЛОГІЄЮ ЧЕРЕВНОЇ ПОРОЖНИНИ

КРІШТАФОР А. А

ЗАХИСТ І ВІДНОВЛЕННЯ КОГНІТИВНИХ ФУНКЦІЙ ПРИ КРИТИЧНИХ СТАНАХ

КРУТЬКО О.М., СЕРЕДЕНКО В.Г.

ПОСТМАСТЕКТОМІЧНИЙ БОЛЬОВИЙ СИНДРОМ - МОЖЛИВОСТІ ПРОФІЛАКТИКИ

НА СУЧАСНОМУ ЕТАПI

КРУТЬКО О.М., СЕРЕДЕНКО В.Г.

НУТРИТИВНА ПІДТРИМКА ЯК СКЛАДОВА КОМПЛЕКСНОЇ ТЕРАПІЇ ХВОРИХ ОНКОЛОГІЧНОГО ПРОФІЛю

КРУТЬКО О.М., СЕРЕДЕНКО В.Г.

ВИКОРИСТАННЯ ЕПІДУРАЛЬНОÏ АНЕСТЕЗІЇ ІНТЕРВЕНЦІЙНОÏ ХІРУРГІЇ

КУЩ К.О., КЛИГУНЕНКО О.М.

ДИНАМІКА РІВНЯ НЕЙРОНСПЕЦИФІЧНОЇ ЕНОЛАЗИ У ХВОРИХ В ГОСТРОМУ ПЕРІОД ІШЕМІЧНОГО ІНСУЛЬТУ 
ЛИЗОГУБ М.В., ГЕОРГІЯНЦ М.А.

ОСОБЛИВОСТІ ПЕРЕБІГУ СПІНАЛЬНОЇ АНЕСТЕЗІЇ ПРИ ОПЕРАТИВНИХ ВТРУЧАННЯХ В ПОЛОЖЕННІ НА ЖИВОТІ

ЛИСЕНКО В.Й., ГОЛЯНІЩЕВ М.О.

РОЗРОБКА ТА ВПРОВАДЖЕННЯ СИМУЛЯЦІЙНОГО НАВЧАННЯ МЕТОДИКАМ PEГIOHAPHOÏ AHECTE3III

ЛІПИЧ О.П., ЛІСЕЦЬКИЙ В.А.

РІВЕНЬ ГЛІКЕМІЇ ПЛАЗМИ КРОВІ ЯК ПОКАЗНИК ЗАГАЛЬНИХ ПРОЯВІВ СТРЕС-РЕАКЦІЇ НА ОПЕРАЦІЙНУ ТРАВМУ ТА АДЕКВАТНІСТЬ АНЕСТЕЗІОЛОГІЧНОГО ЗАБЕЗПЕЧЕННЯ ПРИ АБДОМІНАЛЬНИХ ОПЕРАЦІЯХ

МАЗУР Г.М

МОДЕЛЮВАННЯ ПРОГНОЗУ ПРИ СЕПТИЧНОМУ ШОЦІ

МАТВІЙЧУК М.С., СОЛОЩУК М.О., ФІЛОНОВИЧ Л.М., ІВАНЮТИН А.В.

КОМБІНОВАНА АНЕСТЕЗІЯ (СПІНО-ЕПІДУРАЛЬНА) ПРИ ОПЕРАЦІЇ ТОТАЛЬНОГО

ЕНДОПРОТЕЗУВАННЯ КУЛЬШОВОГО СУГЛОБА

МАТОЛІНЕЦЬ Н.В.

ГАЗОВІ МЕДІАТОРИ ОКСИД АЗОТУ ТА СІРКОВОДЕНЬ ЯК МАРКЕРИ ТЯЖКОСТІ ПОЛІТРАВМИ

МИГАЛЬ І. І., АЛЬБОКРІНОВ А. А., ФЕСЕНКО У. А.

МЕНЕДЖМЕНТ ДИХАЛЬНИХ ШЛЯХХІВ ТА ЯКІСТЬ ВІЗУАЛІЗАЦІЇ ПЛЕВРАЛЬНОЇ ПОРОЖНИНИ ПРИ ВТРУЧАННI ЗА NUSS

НЕСТЕРЕНКО А.Н., ПРОКОПЕНКО Б.Б., КЛИМИКН.А., НЕСТЕРЕНКО Е.А.

ДИНАМИКА ЧУВСТВИТЕЛЬНОСТИ ЕSКАРЕ-ПАТОГЕНОВ - ВОЗБУДИТЕЛЕЙ

ГОСПИТАЛЬНОЙ ХИРУРГИЧЕСКОЙ ИНФЕКЦИИ ЗА ДВУХЛЕТНИИ ПЕРИОД

ЛОКАЛЬНОГО МИКРОБИОЛОГИЧЕСКОГО МОНИТОРИНГА В СТАЦИОНАРАХ КРАМАТОРСКА

ПАВЛЕНКО Г.В., КОЛЯДА В.Н., САВЕНКОВ Д.Ю., МАКАРЕНКО В.В., КРАВЦОВА Е.А., ПАНЧЕНКО Ю.Ю. СЛУЧАЙ УСПЕШНОЙ КОНСЕРВАТИВНОЙ ОСТАНОВКИ КРОВОТЕЧЕНИЯ ИЗ ПАНКРЕАТО-

ГАСТРОАНАСТОМОЗА ПОСЛЕ ПАНКРЕАТО-ДУОДЕНАЛЬНОЙ РЕЗЕКЦИИ (ПДР)

ПАЛЬЖОКА.Д. АРТЕМЕНКО В.Ю., АНДРЕЕВА С.Н.

В ПОИСКАХ ОПТИМАЛЬНОГО ДОСТУПА ДЛЯ ПРОВЕДЕНИЯ ПРОДЛЁННОЙ ИВЛ В УСЛОВИЯХ

ОТДЕЛЕНИЯ АИТ

ПЕРОВА-ШАРОНОВА В.М., АЛЬБОКРІНОВ А.А., ФЕСЕНКО У.А

ПОРУШЕННЯ МЕЗЕНТЕРІАЛЬНОГО КРОВОПЛЙНУ ПРИ ІНТРААБДОМІНАЛЬНІЙ

ГІПЕРТЕНЗІї У ДІТЕЙ

ПОКРИШЕНЬ Д.О.

THRIVE В ЯКОСТІ ОСНОВНОГО МЕТОДУ РЕСПІРАТОРНОÏ ПІТРИМКИ ПІД ЧАС

МІКРОЛАРИНГОХІРУРГІї

ПОЛІНЧУК І.С., ГАРДУБЕЙ Є.Ю., МАЛАХОВ П.С., ПОЛІНЧУК І.М., СИДОРКО Ю.В., ТУРЯНИЦЯ С.В., ЦИМБАЛ Ю.Ф., АРБУЗОВА В.О., СТЕПАНЕНКО П.П.

СУЧАСНА ПАРАДИГМА АНЕСТЕЗІОЛОГІЧНОЇ БЕЗПЕКИ

ПОЛІНЧУК І.С., ПОЛІНЧУК І.М.

ПРОБЛЕМА СКЛАДНОЇ ІНТУБАЦІЇ ТРАХЕЇ В АНЕСТЕЗІОЛОГІЧНІЙ ПРАКТИЦІ

СЕДІНКІН В.А., КЛИГУНЕНКО О.М.

ВПЛИВ КОНЦЕНТРАТУ ПРОТРОМБНОВОГО КОМПЛЕКСУ НА ПОКАЗНИКИ ГОМЕОСТАЗУ

ПРИ ГОСТРІИ АКУШЕРСЬКІЙ КРОВОВТРАТІ

СЕРЕДЕНКО Н.П.

ЗМІНИ ПОКАЗНИКІВ ЦЕНТРАЛЬНОЇ ГЕМОДИНАМІКИ ПОРОДІЛЛІ ПРИ

ОПЕРАТИВНОМУ РОЗРОДЖЕННІ

СИДЮК О.Є., МАЗУР А.П., СИДЮК А.В., КЛІМАС А.С., САВЕНКО Г.Ю.

ПІСЛЯОПЕРАЦІЙНЕ ЗНЕБОЛЕННЯ У ПАЦІЄНТІВ 3 ЕЗОФАГЕКТОМІЄЮ 
СТАРІКОВ А.В., ХИТРИЙ Г.П., ЛЕВЧЕНКО Т.М., АФАНАСЬЄВ С.Є.

ІНФУЗІЙНА ДЕТОКСИКАЦІЙНА ТЕРАПІЯ У ХВОРИХ 3 ЕНДОТОКСИКОЗОМ

СТУПНИЦЬКИЙ М.А., БІЛЕЦЬКИЙ О.В.

ПРОГНОЗУВАННЯ ВИЖИВАННЯ У ПАЦІЄНТІВ 3 ПОЄДНАНОЮ ТОРАКАЛЬНОЮ ТРАВМОЮ

ТІТОВ І.І., ВОЛОШИНСЬКИЙ О.В., МАЙДАНСЬКА І.С., НЕСТОР І.І., ВЕНГРОВИЧ В.В.

СУЧАСНІ МОЖЛИВОСТІ ІНТЕНСИВНОЇ ТЕРАПІЇ ХВОРИХ 3 ДЕКОМПЕНСОВАНИМ ПЕРЕБІГОМ ХОЗЛ

TІТОВ І.І., ВОЛОШИНСЬКИЙ О.В., МАРТИН А.Ю., ВІНТОНЯК І.В., НЕСТОР І.І.

ОЦІНКА ЕФЕКТИВНОСТІ НЕЙРОПРОТЕКТОРНОÏ ТЕРАПІЇ ПРИ ЧМТ

ТІТОВ І.І., ДАНИЛЮК Т.Т., ВЕНГРОВИЧ В.В., НЕСТОР І.І., БОЙКО М.А.

МІКРОБІОЛОГІЧНЕ ОТОЧЕННЯ БАГАТОПРОФІЛЬНОГО ВІДДІЛЕННЯ ІНТЕНСИВНОЇ ТЕРАПІЇ

ТА АНТИБІОТИКОРЕЗИСТЕНТНІСТЬ ЗБУДНИКІВ

ТІТОВ І.І., КІНДЯК І.Р., ПРОТАС В.В., КОСТИРКО Р.Б., НЕСТОР І.І., БАХМАТ Н.М. ДОСВІД ЗАСТОСУВАННЯ ЕСМОЛОЛУ ГІДРОХЛОРИДУ ПРИ ЛІКУВАННІ ГІПЕРТЕНЗИВНИХ РЕАКЦІЙ I ТАХІАРИТМІЙ ПІД ЧАС ЗАГАЛЬНОГО ЗНЕБОЛЕННЯ

ТІТОВ І.І., МАРТИН А.Ю., ВІНТОНЯК І.В., ГРИЩЕНКО С., ВЕНГРОВИЧ В.В.

СУЧАСНИЙ ПОГЛИБЛЕНИЙ ВОЛЮМЕТРИЧНИИ МОНІТОРИНГ ГЕМОДИНАМІКИ

ФЕДОРОВ Ю.П, ПРАЩЕРУК П.В, ПУГАЧЕВ В.А, МЕРЕНКОВ В.Г., КОВШАРЬ Н.П.

АНЕСТЕЗИОЛОГИЧЕСКОЕ СОПРОВОЖДЕНИЕ ПРИ «ГИБРИДНЫХ О ОПЕРАЦИЯХ НА СОСУДАХ НИЖНИХ КОНЕЧНОСТЕЙ

ФЕДОРОВ Ю.П, ПУГАЧЕВ В.А, ПРАЩЕРУК П.В, АНТОШКИН Р.В., КОВШАРЬ Н.П.

ГИПЕРБАРИЧЕСКАЯ ОКСИГЕНАЦИЯ КАК МЕТОД В КОМПЛЕКСНОМ ЛЕЧЕНИИ ИШЕМИИ НИЖНИХ КОНЕЧНОСТЕЙ

ФЕДОРОВ Ю.П, ПУГАЧЕВ В.А, ПРАЩЕРУК П.В, ГРЕЧИШКИНА Ю.А., КОВШАРЬ Н.П.

ГИПЕРБАРИЧЕСКАЯ ОКСИГЕНАЦИЯ КАК МЕТОД В КОМПЛЕКСНОМ ЛЕЧЕНИИ ГРЫЖ

МЕЖПОЗВОНКОВЫХ ДИСКОВ ПОЗВОНОЧНИКА

ФІЛІМОНОВ Р.В., КОБЕЛЯЦЬКИЙ Ю.Ю., ПОТАЛОВ С.О., ФІЛІМОНОВА І.В., ШАПОВАЛОВ Є.М. ОПЕРАТИВНЕ ЛІКУВАННЯ ХВОРИХ 3 СИНДРОМОМ ДІАБЕТИЧНОЇ СТОПИ В УМОВАХ

PEГIOHAPHOÏ AHECTE3III

ФРОНЧКО В. П., СЕМИЦЬКИЙ Я. В., МЕЛЬНИК Р. В., ОРЛЕЦЬКИЙ Б. Ю.

ОЦІНКА ПОКАЗНИКА ВЕНТИЛЯЦІЙНОГО ТИСКУ ДЛЯ КОНТРОЛЮ МЕХАНІЧНОЇ ВЕНТИЛЯЦІЇ

ХИТРИЙ Г.П., МОШКІВСЬКИЙ В.М.

ОПТИМІЗАЦІЯ НАДАННЯ НЕВІДКЛАДНОЇ МЕДИЧНОЇ ДОПОМОГИ В ЗОНІ ПРОВЕДЕННЯ ООС ШЛЯХОМ ВПРОВАДЖЕННЯ УРГЕНТНОЇ СОНОГРАФІЇ

ХИТРИЙ Г.П., ХРОМИХІНА Н.А., ГЛАДУШ А.В., ХОРОШУН В.М., ЧУЙКО Ю.М. ОСОБЛИВОСТІ АНЕСТЕЗІОЛОГІЧНОЇ ДОПОМОГИ ПОСТРАЖДАЛИМ ПРИ ВОГНЕПАЛЬНИХ ПОРАНЕННЯХ В УМОВАХ ЗБРОЙНОГО КОНФЛІКТУ

ЧЕРНІЙ В. І., ЄВСЄЄВА В. В.

ЧИ Є АЛЬТЕРНАТИВА ФЕНТАНИЛУ В СХЕМІ ІНТРАОПЕРАЦІЙНОЇ МУЛЬТИМОДАЛЬНОЇ

АНАЛГЕЗІЇ ПІД ЧАС ЛАПАРОСКОПІЧНИХ БАРІАТРИЧНИХ ВТРУЧАНЬ У ПАЦІЄНТІВ 3 МОРБІДНИМ ОЖИРІННЯМ?

ШКУРУПІЙ Д.А., ТЕРІВ П.С.

ПРОГНОСТИЧНІ ФАКТОРИ РОЗВИТКУ НЕДОСТАТНОСТІ ЦИНКУ У НЕВРОЛОГІЧНИХ ХВОРИХ, ЯКІ ПОТРЕБУЮТЬ ІНТЕНСИВНОї ТЕРАПII

ШКУРУПІЙ Д.А., ХОЛОД Д.А.

ГАСТРОІНТЕСТИНАЛЬНА НЕДОСТАТНІСТЬ В СТРУКТУРІ ГІПОКСИЧНО-ІШЕМІЧНИХ УРАЖЕНЬ НОВОНАРОДЖЕНИХ: МЕХАНІЗМИ ФОРМУВАННЯ ТА КОРЕКЦІЯ 